\title{
Immobilization of High-Level Defense Waste in a Slurry-Fed Electric Glass Melter
}

\author{
R. A. Brouns \\ G. B. Mellinger \\ T. A. Nelson \\ K. H. Oma
}

November 1980

Prepared for the U.S. Department of Energy under Contract DE-AC06-76RLO 1830

Pacific Northwest Laboratory Operated for the U.S. Department of Energy by Battelle Memorial Institute 
This report was prepared as an account of work sponsored by the United States Government. Neither the United States nor the Department of Energy, nor any of their employees, nor any of their contractors, subcontractors, or their employees, makes any warranty, express or implied, or assumes any legal liability or responsibility for the accuracy, completeness or usefulness of any information, apparatus, product or process disclosed, or represents that its use would not infringe privately owned rights.

The views, opinions and conclusions contained in this report are those of the contractor and do not necessarily represent those of the United States Government or the United States Department of Energy.

\author{
PACIFIC NORTHWEST LABORATORY \\ operated by \\ BATTELLE \\ for the \\ UNITED STATES DEPARTMENT OF ENERGY \\ Under Contract DE-AC06-76RLO 1830
}

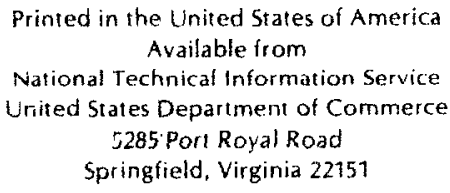

Price: Printed Copy 5 *; Microfiche $\$ 3.00$

$\begin{array}{lr}001-025 & \$ 4.00 \\ 026-050 & \$ 4.50 \\ 051-075 & \$ 5.25 \\ 076-100 & \$ 6.00 \\ 101-125 & \$ 6.50 \\ 126-150 & \$ 7.25 \\ 151-175 & \$ 8.00 \\ 176-200 & \$ 9.00 \\ 201-225 & \$ 9.25 \\ 226-250 & \$ 9.50 \\ 251-275 & \$ 10.75 \\ 276-300 & \$ 17.00\end{array}$




\section{DISCLAIMER}

This report was prepared as an account of work sponsored by an agency of the United States Government. Neither the United States Government nor any agency Thereof, nor any of their employees, makes any warranty, express or implied, or assumes any legal liability or responsibility for the accuracy, completeness, or usefulness of any information, apparatus, product, or process disclosed, or represents that its use would not infringe privately owned rights. Reference herein to any specific commercial product, process, or service by trade name, trademark, manufacturer, or otherwise does not necessarily constitute or imply its endorsement, recommendation, or favoring by the United States Government or any agency thereof. The views and opinions of authors expressed herein do not necessarily state or reflect those of the United States Government or any agency thereof. 


\section{DISCLAIMER}

Portions of this document may be illegible in electronic image products. Images are produced from the best available original document. 
PNL -3372

UC -70

IMMOBILIZATION OF HIGH-LEVEL DEFENSE WASTE IN A SLURRY-FED ELECTRIC GLASS MELTER
R. A. Brouns
G. B. Mellinger
T. A. Nelson
K. H. Oma

November 1980

Prepared for the U.S. Department of Energy under Contract DE-AC06-76RLO 1830

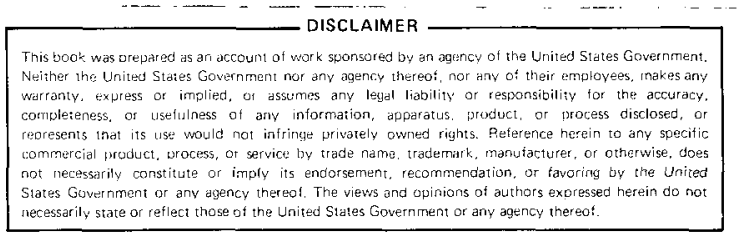

Pacific Northwest Laboratory Richland, Washington 99352 
0

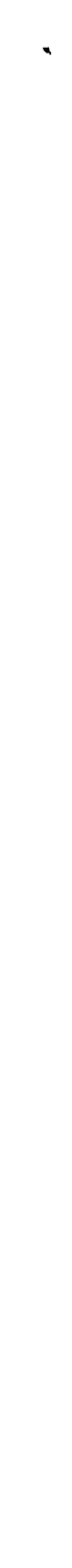




\section{ACKNOWLEDGMENTS}

The authors would like to acknowledge the assistance of J. L. Buelt, W. J. Bjorklund, W. C. Buchmiller and K. E. Eliason for providing input to this report. 


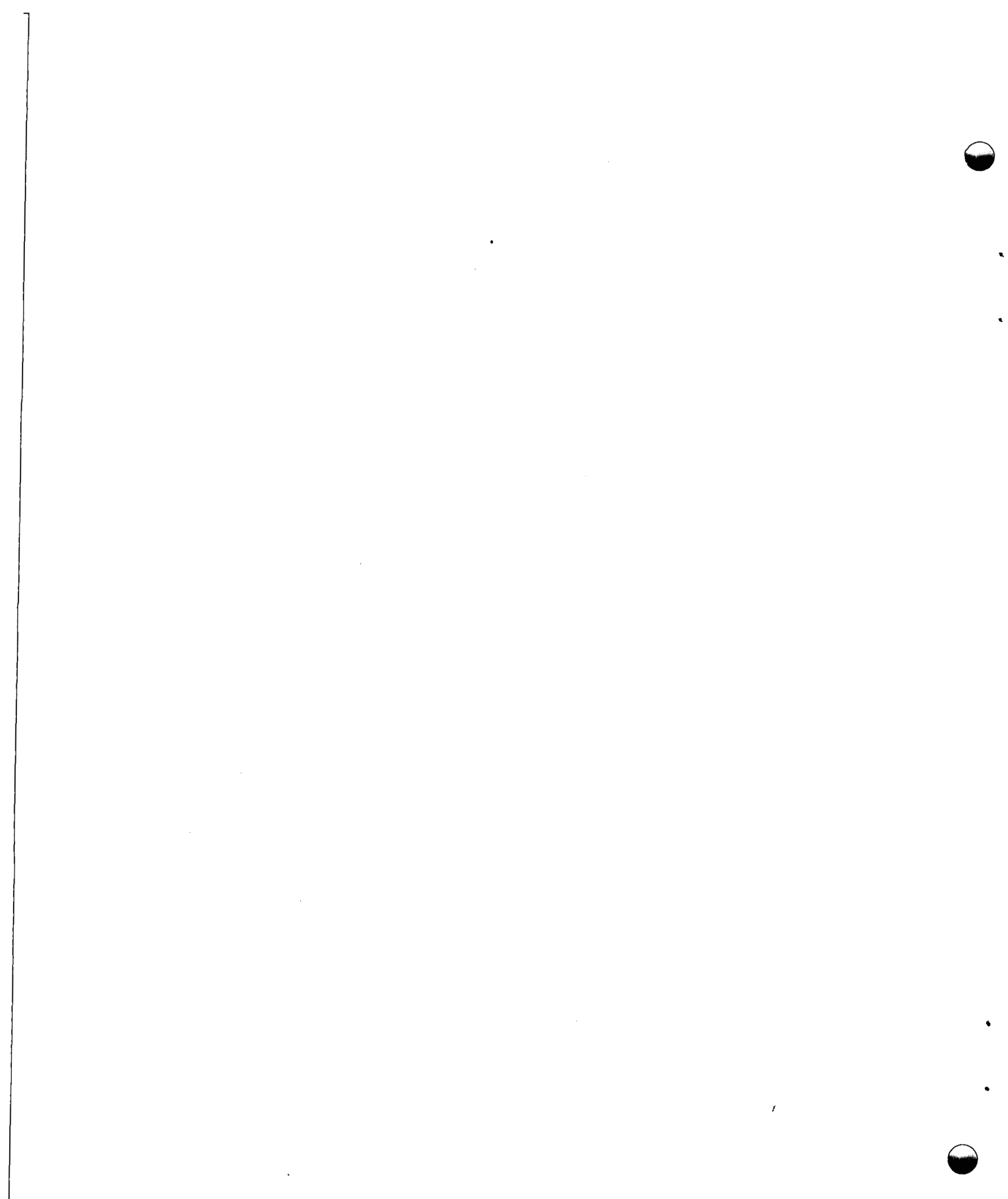


Scoping studies have been performed at the Pacific Northwest Laboratory related to the direct liquid-feeding of a generic high-level defense waste to a joule-heated ceramic melter. Tests beginning on the laboratory scale and progressing to full-scale operation are reported. Laboratory work identified the need for a reducing agent in the feed to help control the foaming tendencies of the waste glass. These tests also indicated that suspension agents were helpful in reducing the tendency of solids to settle out of the liquid feed. Testing was then moved to a larger pilot-scale melter (designed for $22.5 \mathrm{~kg} / \mathrm{h}$ ) where verification of the flowsheet examined in the lab was accomplished. It was found that the reducing agent controlled foaming and did not result in the precipitation of metals. Pumping problems were encountered when slurries with higher than normal solids content were fed.

A demonstration (designed for $250 \mathrm{~kg} / \mathrm{h}$ ) in a full-scale melter was then made with the tested flowheet; however, the amount of reducing agent had to be increased. In addition, it was found that feed control needed further development; however, steady-state operation was achieved giving encouraging results on process capacities. During steady-state operation, ruthenium losses to the offgas system averaged less than $0.16 \%$, while cesium losses were somewhat higher, ranging from 0.91 to $24 \%$ and averaging $13 \%$. Particulate decontamination factors from feed to offgas in the melter ranged from $5 \times 10^{2}$ to greater than $10^{3}$ without any filtration or treatment. Approximately $1050 \mathrm{~kg}$ of glass was produced from $2900 \mathrm{~L}$ of waste at rates up to $40 \mathrm{~kg} / \mathrm{h}$. 


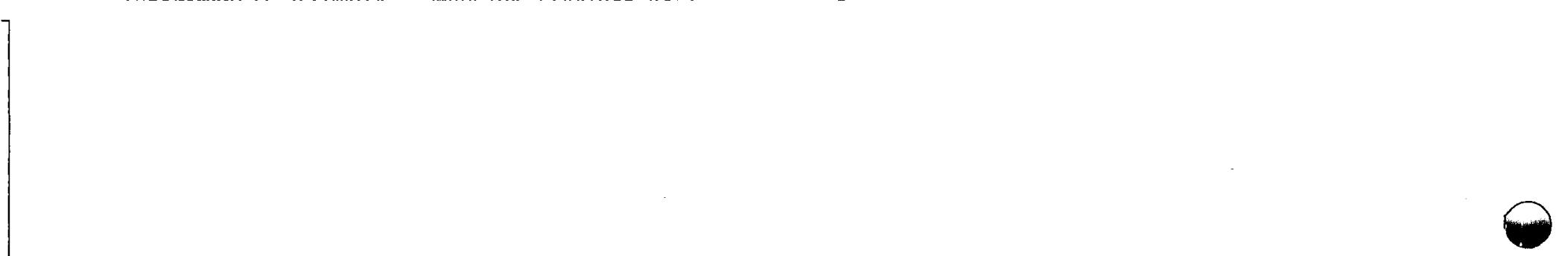

$\ominus$

$\theta$ 


\section{CONTENTS}

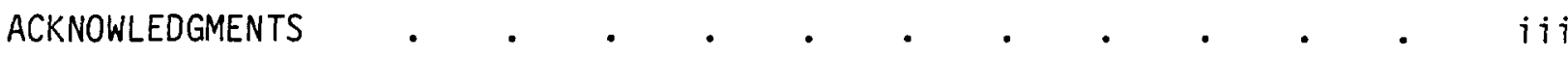

SUMMARY

FIGURES

TABLES

INTRODUCTION

CONCLUSIONS

BACKGROUND OF HIGH-LEVEL NUCLEAR WASTE IMMOBILIZATION TECHNOLOGY .

LIQUID-FED PROCESS DESCRIPTION

LABORATORY SCOPING TESTS •

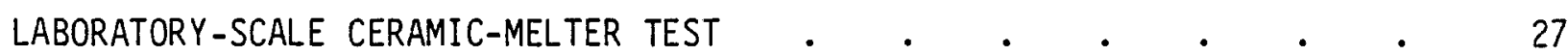

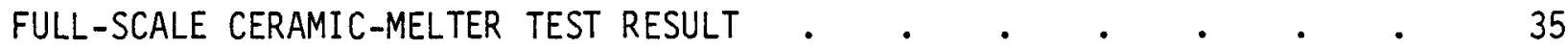

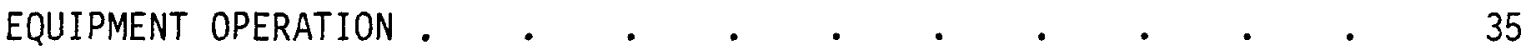

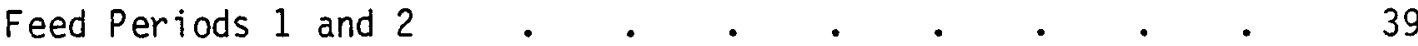

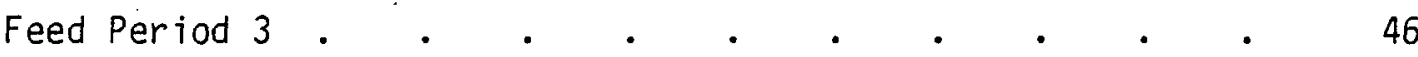

Feed Periods 4 and 5 . 5 . $\quad . \quad$. . . . . . . 46

Feed Period 6 .

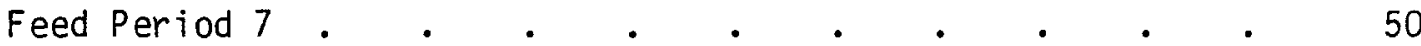

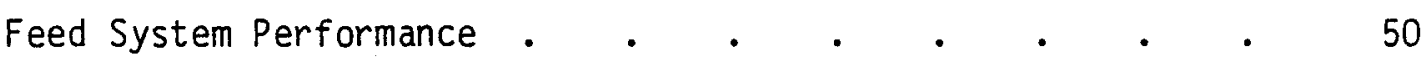

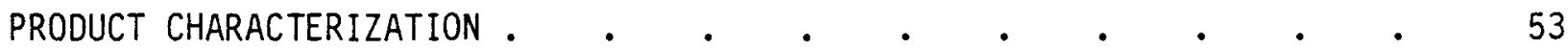

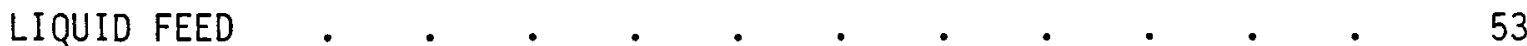

BATCH COVER . . . . . . . . . . . . . . . 57

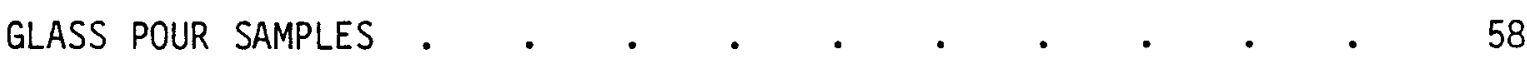

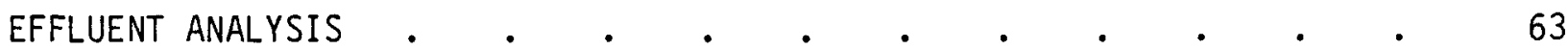

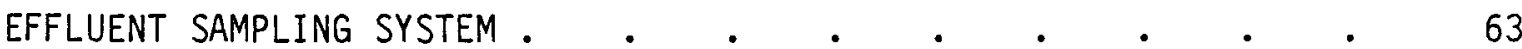




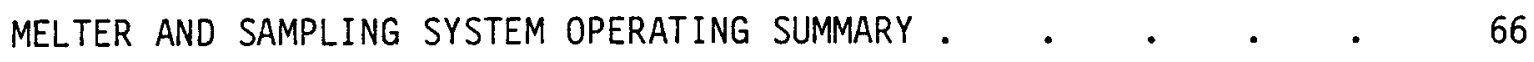

RESULTS

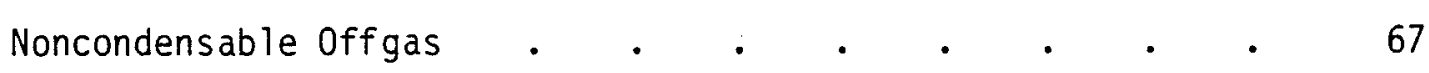

Volatilized and Entrained Constituents . . . . . . 68

Plating and Particulate Constituents . . . . . . . 71

Particle Loading and Size Distribution . . . . . . 73

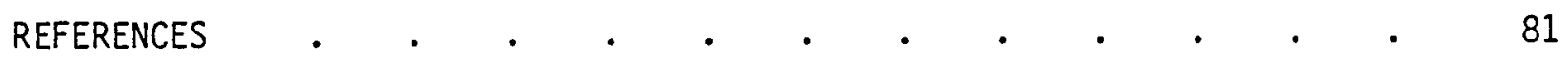

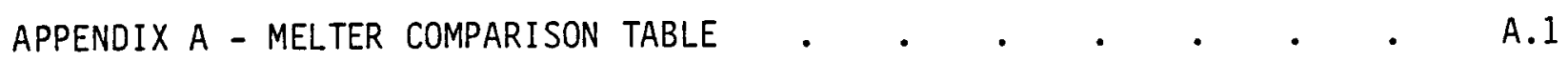

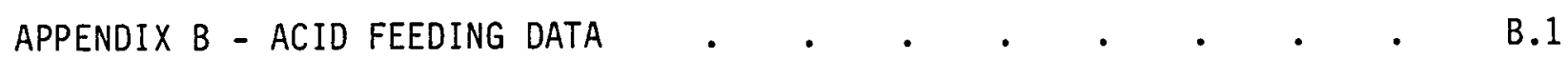

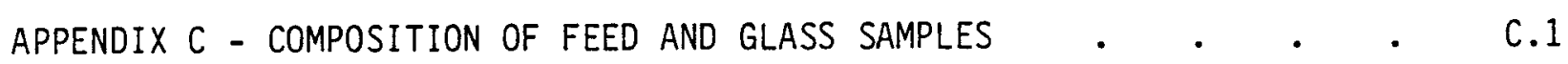

APPENDIX D - PROPOSED MECHANISMS FOR FOAM GENERATION $\quad$ • $\quad$ • $\quad$ • $\quad$ D 0.1 


\section{FIGURES}

1 Engineering-Scale Ceramic Melter Schematic . . . . $\quad$. 8

2 LFCM Schematic . . . . . . . . . . . 10

3 Liquid-Fed Process Flowsheet . . . • • • • . 13

4 Fully Flooded Condition . . . . . . . . . . . 16

5 Nonflooded Condition. . . . . . . . . . . . 17

6 LFCM Ionic Boosters . . . . . . . . . . . . 18

7 Liquid-Feeding Apparatus . . . . . . . • . . . 20

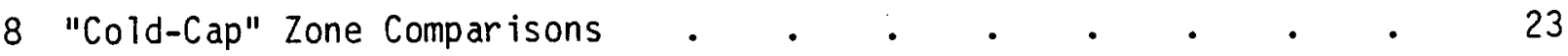

9 "Cold-Cap" Depictions During Runs $2 \mathrm{~A}$ and $2 \mathrm{~B}$. $\quad . \quad$. 25

10 Experimental Ceramic Melter . . . . . . . . 28

11 Liquid-Feed Control Loop . . . . . . . . . . 29

12A,B ECM-79-2 Liquid-Fed Run Feed Schedule . . . . . . 32

13 ECM-79-2 Temperature Profiles . . . . . . . . 33

14 Liquid-Fed Process . . . . . . . . . . . 37

15 LFCM Glass Temperatures and Feed Schedule . . . . . 40

16 Electrode Power and Resistance . . . . . . . . . 41

17 LFCM Electrode Temperatures . . . . . . . . . . 42

18 LFCM Glass-Temperature Profiles . . . . . . . 45

19 LFCM Heat Balance . . . . . . . . . . . . 48

20 LFCM Energy Balance . . . . . • . • • • . 51

21 Oxide Composition of Liquid Feed, Percentage of Target Value . . 54

22 Oxide Composition of Liquid Feed, Percentage of Target Value . . 55

23 Oxide Composition of Liquid Feed, Percentage of Target Value . • 55 
24 Total Oxide Loading of Liquid Feed, Percentage of Target, g of $0 x i d e / L$ of Feed.

25 Composition of Liquid Feed, Percentage of Target, $g$ of $0 x i d e / L$ of Feed . . . . . . . . . . . . . .

26 Composition of Liquid Feed, Percentage of Target, $g$ of Oxide/L of Feed

27 Composition of Liquid Feed, Percentage of Target, g of 0xide/L of Feed

28 Density of Liquid Feed as a Function of Time . . . . . .

29 Oxide Composition of Pour Glass Samples, Percentage of Target Value.

30 LFCM Effluent Sampling System . . . . . . . . . . . . . . . . .

31 Particle Count Versus Particle Size Liquid-Fed Ceramic Melter: Idling

32 Mass Versus Particle Size Liquid-Fed Ceramic Melter: Idling

33 Particle Count Versus Particle Size Liquid-Fed Ceramic Melter: During Feeding

34 Mass Versus Particle Size Liquid-Fed Ceramic Melter: During Feeding 


\section{TABLES}

1 Batch Formulations of Laboratory Scoping Studies . . . . . 21

2 Feed and Product Makeup for ECM Liquid Fed Run . . . . 30

3 Particle Size of Frit-211 for ECM Liquid-Feeding Tests . . . 31

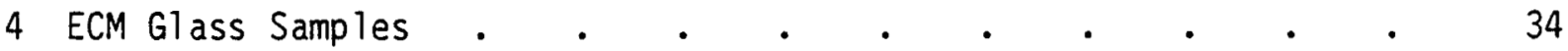

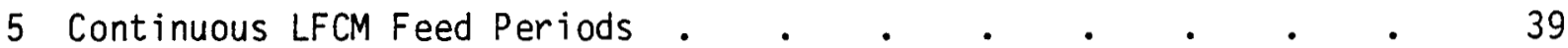

6 Feed and Product Makeup for LFCM Liquid-Fed Run . . . . . 43

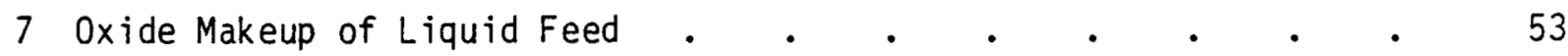

8 Compositions of Samples from Batch Cover $\quad$. $\quad$. $\quad$. $\quad$. 60

\begin{tabular}{l}
9 Compositions of Glasses Taken from Melt-Batch Cover \\
Interface. \\
\hline
\end{tabular}

10 Liquid-Feed Composition . . . . . . . . . . . . 67

11 Run Conditions During Scrubbing System Sampling . . . . . 68

12 Average Noncondensable Offgas Composition During Liquid Feeding .

13 Elemental Offgas Concentrations and Steady-State Decontamination Factors $. \quad . \quad . \quad . \quad . \quad . \quad . \quad . \quad$. 70

14 Chloride, Nitrate and Sulfate Offgas Concentrations . $\quad$. $\quad 71$

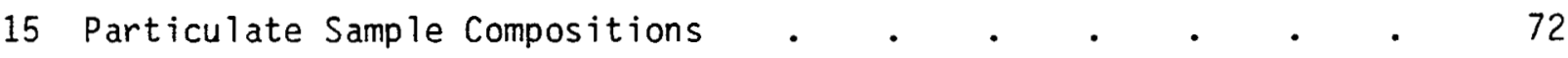

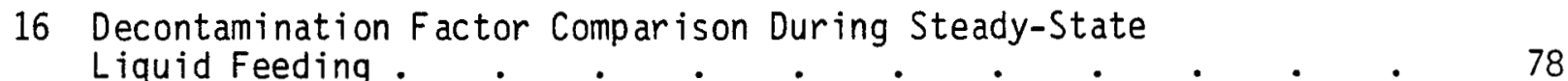

17 Particulate Loadings and Diameter Range in the Offgas

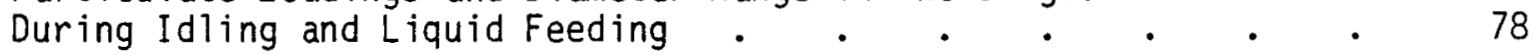

A.1 Operating History of Ceramic Melters at PNL . . . . . . . A.1

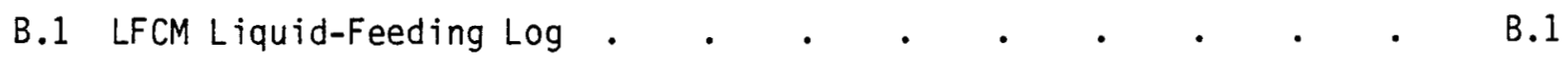

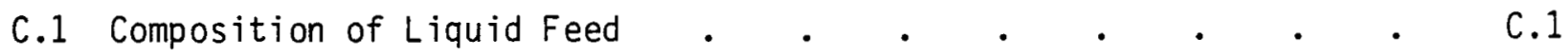

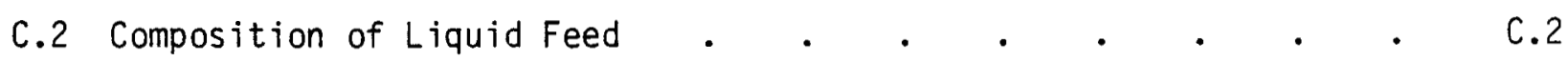

C.3 Compositions of Pour Glass Samples . . . . . . . . . . C.3 


\section{INTRODUCTION}

Since 1975, researchers at the Pac ific Northwest Laboratory (PNL) have been developing a process for continuously converting nuclear waste to a stable glass by feeding a mixture of liquid waste and glass formers directly to an electrically heated melter. Most of the development work has been with simulated, acidic power-reactor wastes; however, recent emphas is has been placed on the study of simulated defense wastes. This report discusses the results of a study in which the slurry-feeding technique was used to introduce a simulated generic high-level defense waste into an electric glass melter. The study consisted of a series of scoping tests which began in the laboratory and progressed to a full-scale demonstration. The defense waste chosen for the study was modeled after that in existence at the Savannah River Plant in South Carolina.

A description of the process, the test results, and an analysis of the effluent sampling system and its results are given. 
0 • 


\section{CONCLUSIONS}

Direct liquid feeding of a generic defense-waste slurry to an electrically heated melter is a viable alternative to the calciner-melter system. Although processing rates were sacrificed, benefits included:

- improved mixing of the waste with the glass formers

- low particulate entrainment without filtration

- simplified operations.

Specific results related to equipment operation, product characterization and effluent analysis follow.

\section{EQUIPMENT OPERATION}

- Processing of the concentrated defense-waste glass slurry with 33 wt\% solids did not create a suspension or transport problem except for minor settling of the manganese dioxide at low feedrates.

- Steady-state operation was achieved, giving encouraging process capacities results.

- Bridging of the "cold cap" occurred with the feed formulation chosen for the full-scale tests.

- Flooded operation was possible without pressurization.

- Successful recovery from both bridging and overfeeding was achieved by a temporary shutdown of the feeding process.

- A buildup of feed material collected on the walls and lid of the melter during operation. Periodic removal of this buildup may be necessary during extended operation to avoid problems such as feed-entry port blockage.

- Agreement between the full-scale testing and lab-scale tests in relation to method of offgas release and bridging potential was not as good as was believed it would be. These differences may be the result of either the 
finer mesh frit used during the full-scale tests or the insufficient run time in the lab-scale tests to reach steady-state condition.

- The addition of a reducing agent to the feed controlled foaming without resulting in the precipitation of metals.

\section{PRODUCT CHARACTERIZATION}

- A reduction in the formation of insoluble precipitate in the melter was noted.

\section{EFFLUENT ANALYSIS}

- The average loss to the offgas system of radionuclide substitutes during steady-state melter operation was: ruthenium, $0.16 \%$; antimony, $0.11 \%$; tellurium, 0.44\%; and cesium, 13\%. It is not understood why Cs losses were high. Previous work with power-reactor wastes indicates Cs losses between 0.4 and $1.4 \%$.

- The average particle loadings in the melter offgas during melter idling are roughly the same as those from the sintered metal filters of a spray calciner. Particulate loadings during liquid feeding are approximately 100 times those of sintered metal filters of a spray calciner. Particle diameter ranges are roughly the same for idling, liquid feeding and spray calcination.

- During melter operation, less than $0.2 \%$ of waste elements escaped the melter into the offgas system.

- Between 70 and $90 \%$ of the elements leaving the melter in the offgas are volatilized. The remaining 10 to $30 \%$ leave by physical entrainment.

- Of the major glass elements, chloride and sodium are most prevalent in the offgas followed by boron, cesium and lithium.

- Melter offgas solids losses are typically highest during steady-state liquid feeding and lower during startup or foaming states. 
- The melter plenum and offgas system must be made of corrosion-resistant materials because of the potential chloride, sulfate and nitrate volatility for this process.

- Oxygen is released from the melt during liquid feeding and absorbed during idling. 


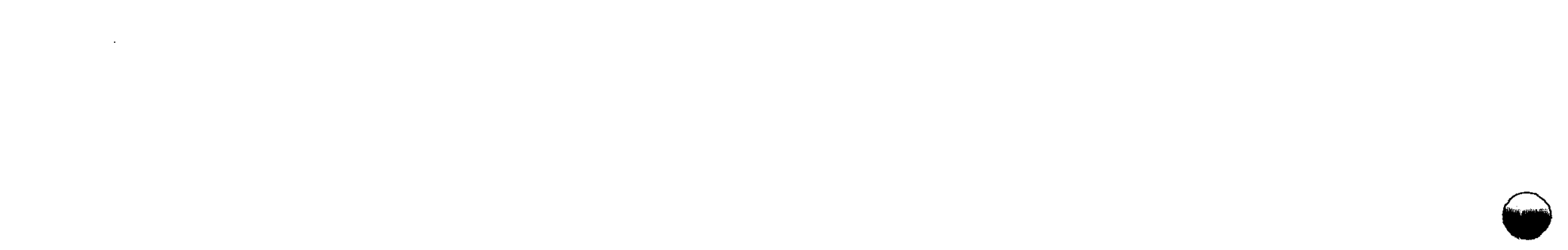

$\ominus$

6
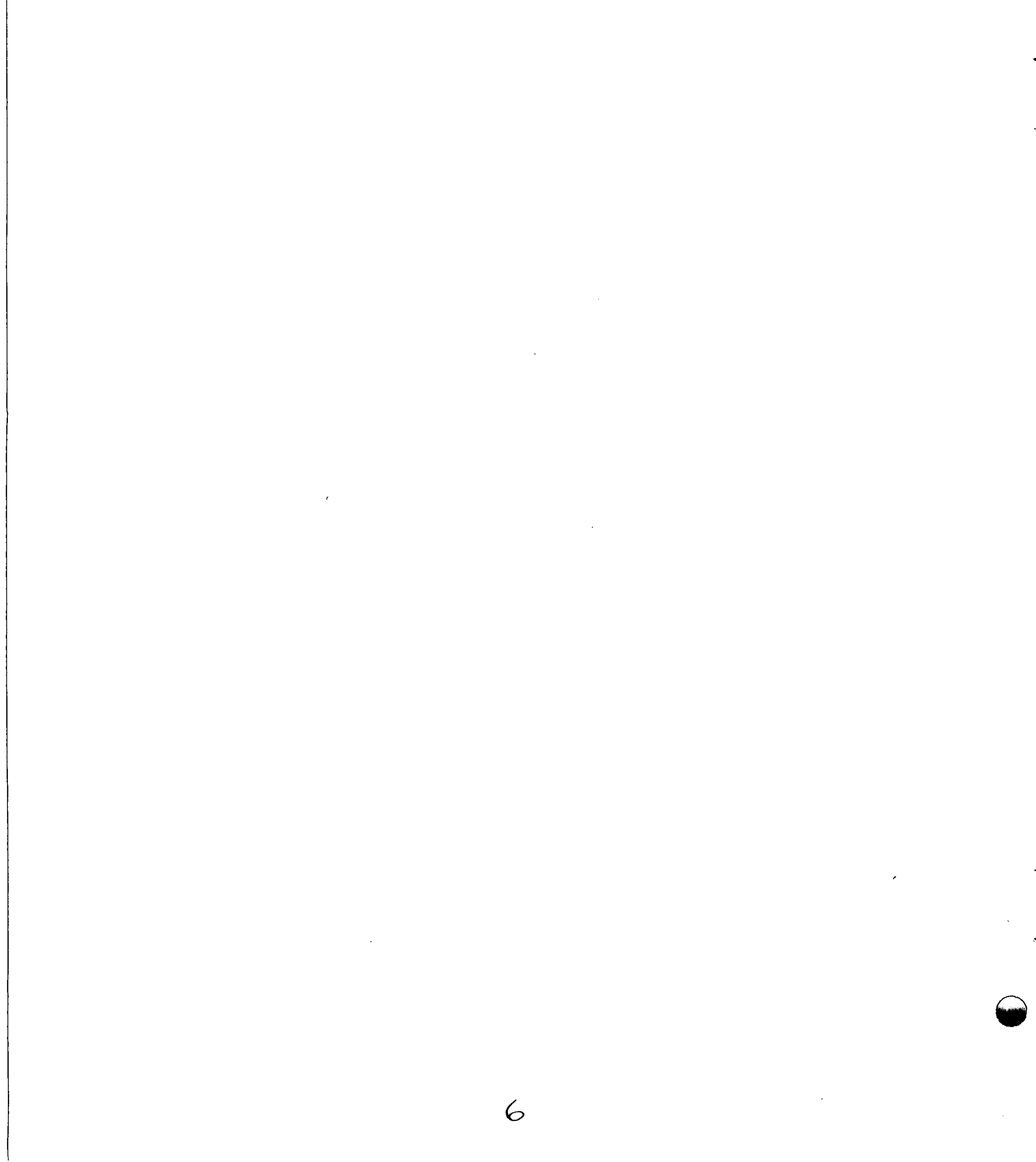


\section{BACKGROUND OF HIGH-LEVEL NUCLEAR-WASTE IMMOBILIZATION TECHNOLOGY}

The search for a suitable method of immobilizing high-level nuclear waste for permanent storage has led to the development of several solid waste forms that appear to be capable of accomplishing this task. Among these waste forms is the chemically and physically durable glass.

Several methods for the fixation of high-level waste in glass are being developed at PNL. The technology for the conversion of high-level liquid waste to glass exists and has been demonstrated in a shielded facility with actual high-level waste (Wheelwright et al. 1979). Improvements, however, in the waste-to-glass conversion technology are continually being made at PNL. An example of such an improvement is the ceramic-lined melter whose design and testing began more than $7 \mathrm{yr}$ ago at PNL. This equipment has the advantage of allowing a continuous process capable of operating at high temperatures and producing a homogeneous product. Another potential improvement in the technology is the elimination of the conventional calcination step by direct liquidfeeding of the slurried waste and glass formers to the melter.

The development of direct liquid-feeding began at PNL in 1975 with the Engineering-Scale Ceramic Melter (ESCM) (Figure 1). This work has been described in detail in other reports (Chapman 1976; Chapman and Buelt 1977).

This melter used two plate electrodes that entered from above the molten glass at opposite ends of the melting cavity. The ESCM was operative for $2 \mathrm{yr}$ with only one shutdown period before it was permanently decommissioned and examined. Ten liquid-fed experiments were performed with this melter. Summary data on the ESCM are presented in Appendix A.

An attempt to feed liquid waste and frit as separate streams to the ESCM proved to be unsatisfactory (Chapman 1976). After only a short time it was found that the frit would settle through the slurry and melt rapidly while the waste would calcine and form a cake or crust that would not melt well in the absence of the fluxing agents in the frit. Slurrying of frit directly with the waste alleviated this separation as well as eliminated other problems associated with a poorly mixed batch. Thus, the success of the liquid feeding 


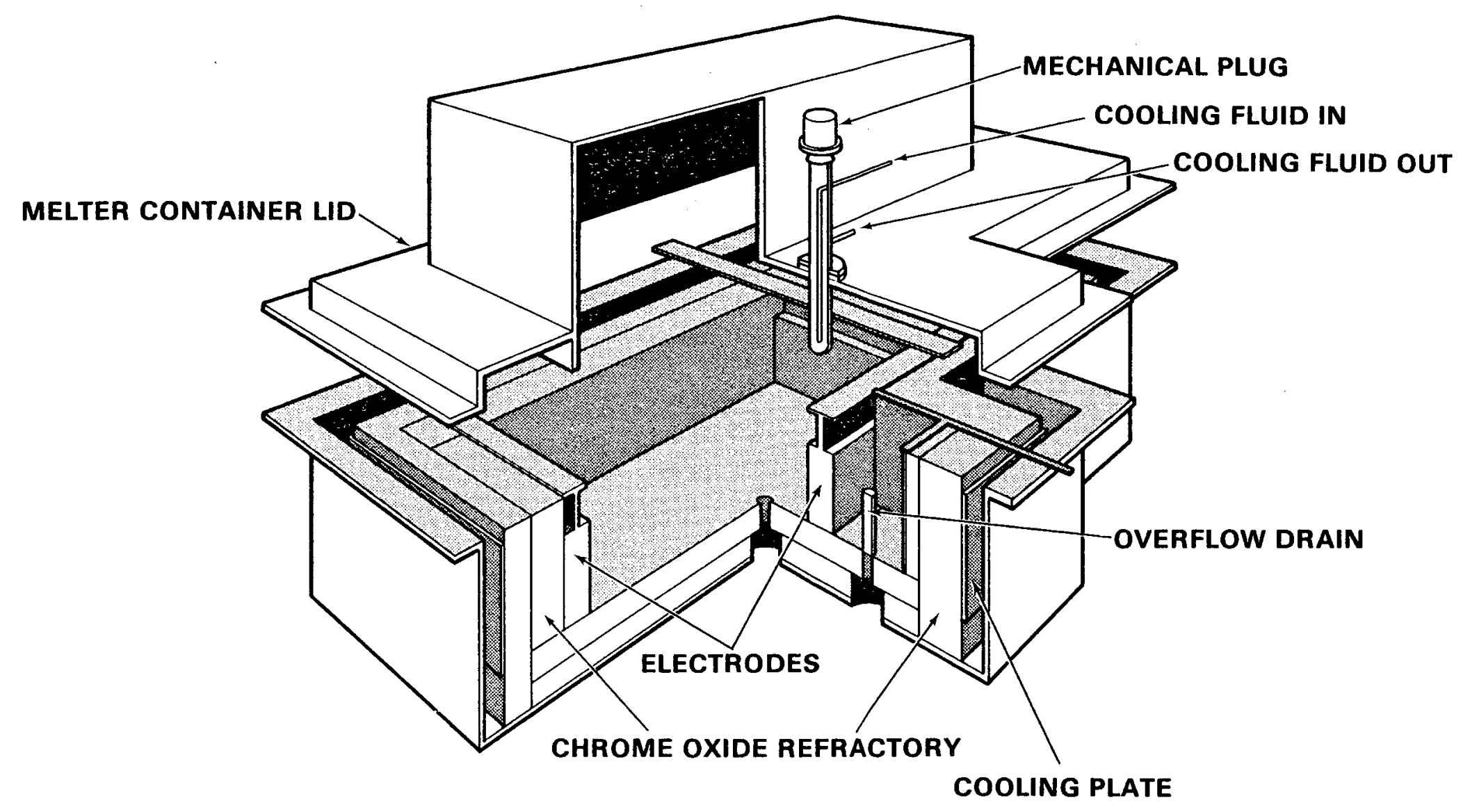

FIGURE 1. Engineering-Scale Ceramic-Melter Schematic 
tests in the ESCM led to the construction of a larger-scale melter known as the LFCM designed specifically for liquid feeding.

The Liquid-Fed Ceramic Melter (LFCM) (Figure 2) was originally designed for feeding acidic-powder reactor wastes. Approximately $250 \mathrm{~h}$ of testing with acidic-powder compositions in $>25$ experiments with $\sim 10,000 \mathrm{~L}$ of simulated waste were accomplished. Summary data for this work is in Appendix B. These tests provided the data for evaluating the liquid-fed operation during the startup and shutdown of the feeding processes and during steady-state operation.

The LFCM (see Table A.1 for operating capacities) has two sets of electrodes. Each set consists of two electrodes, one at each end of the melting cavity and located at different heights. Both pairs of electrodes enter from the side of the melter and are completely submerged in the molten glass. The upper set of electrodes has twice the surface area of the lower set. This design allows for a large amount of the power to be generated near the melting surface area. The lower set of electrodes is used for power generation near the floor. Raising the floor temperature should result in better convective mixing and reduce the precipitation of crystals. Another feature of this design is that it allows the melter to be idled primarily on the lower electrode set. By doing so, the exposed glass surface-temperature is lower. This reduces the heat losses and, more importantly, reduces volatility during idling. 


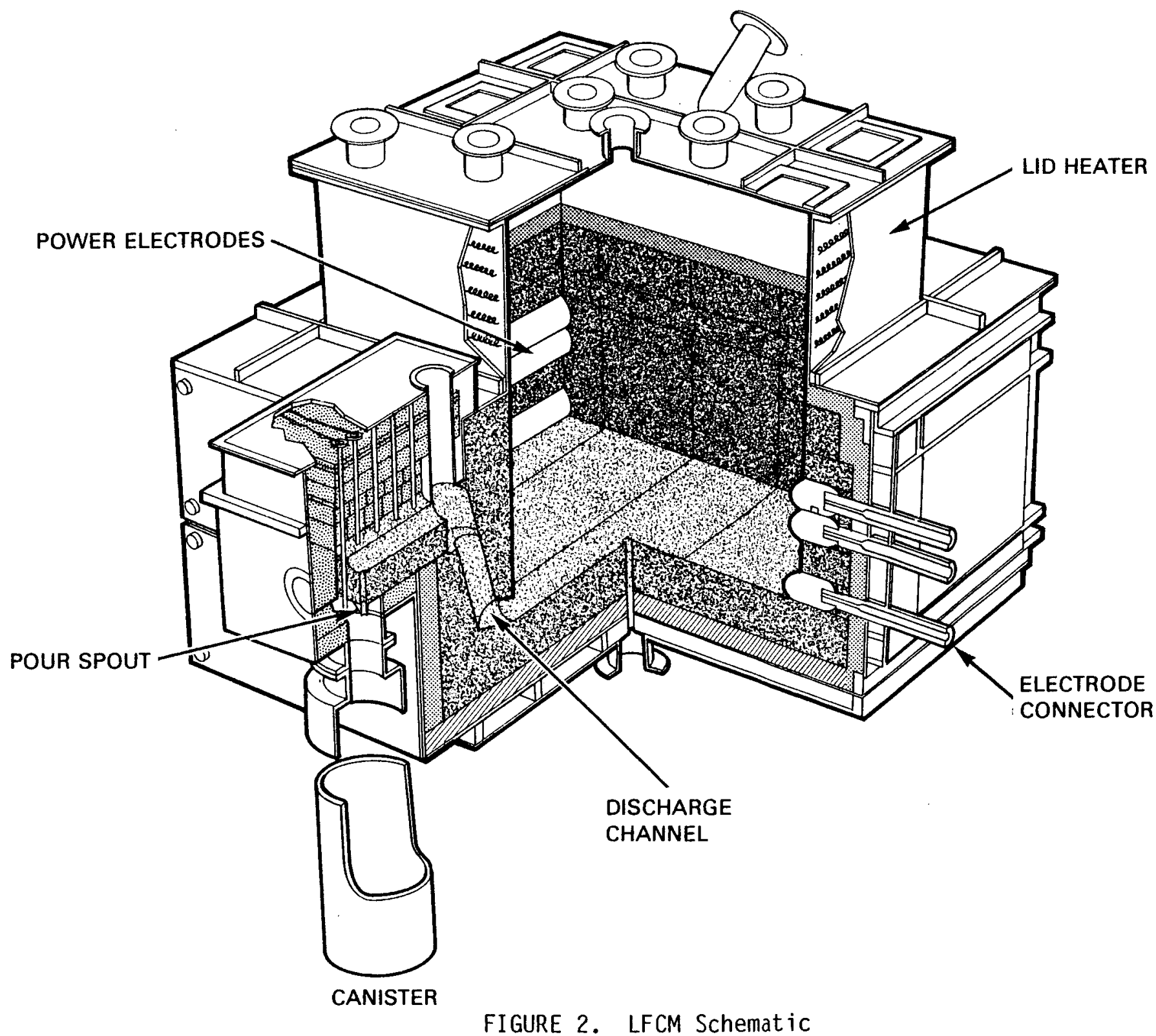

FIGURE 2. LFCM Schematic 


\section{LIQUID-FED PROCESS DESCRIPTION}

In the liquid-fed process (Figure 3 ) the glass formers are mixed with liquid waste in the feed tank before the waste slurry is fed to the melter. Normally a crust of solid, unmelted material in the tank separates the slurry from the molten glass. This solid crust and boiling slurry are known as the "cold cap." Heat from the molten glass is transferred through the crust to evaporate the slurry's moisture and to form additional crust. As the crust melts into the glass, additional gases are generated that result from its decomposition. The steam and gases collect in the area above the melting surface, which is maintained with a slight negative pressure $(-250 \mathrm{~mm}$ of water). From there they are removed by an offgas system. Particulates and volatiles collected in this system are recycled to the melter as required. The waste glass flows continuously into a receiving canister.

Direct liquid-feeding has distinct advantages over a calciner melter system. One major advantage is the simplification of the equipment by elimination of the calciner. Other advantages are:

- improved mixing of the waste and glass formers

- low particulate entrainment or dusting without filtration

- reduced hot-cell facility space

- reduced noncondensable effluents by elimination of atomizing air.

The potential for lower volatility because of the refluxing or scrubbing action of the liquid pool covering the "cold cap" also appears to be an advantage, but this has not been tested sufficiently. Volatility during liquid feeding with a simulated commercial waste was shown to be low for all components except Ru. Its volatility was reduced substantially, however, by partially denitrating the feed (Buelt and Chapman 1979).

One disadvantage of the liquid feeding process compared to calcine feeding is the reduction of processing rates for a specific melter size. However, with higher concentration feeds and evaporative boosting techniques, comparable rates are conceivable. A concern with the liquid feeding process is the possible decrease in melter refractory life due to the higher potential for thermal shock. Pressurizations of the melter, caused by unstable "cold caps," can 
$\bullet$

$\theta$

12 

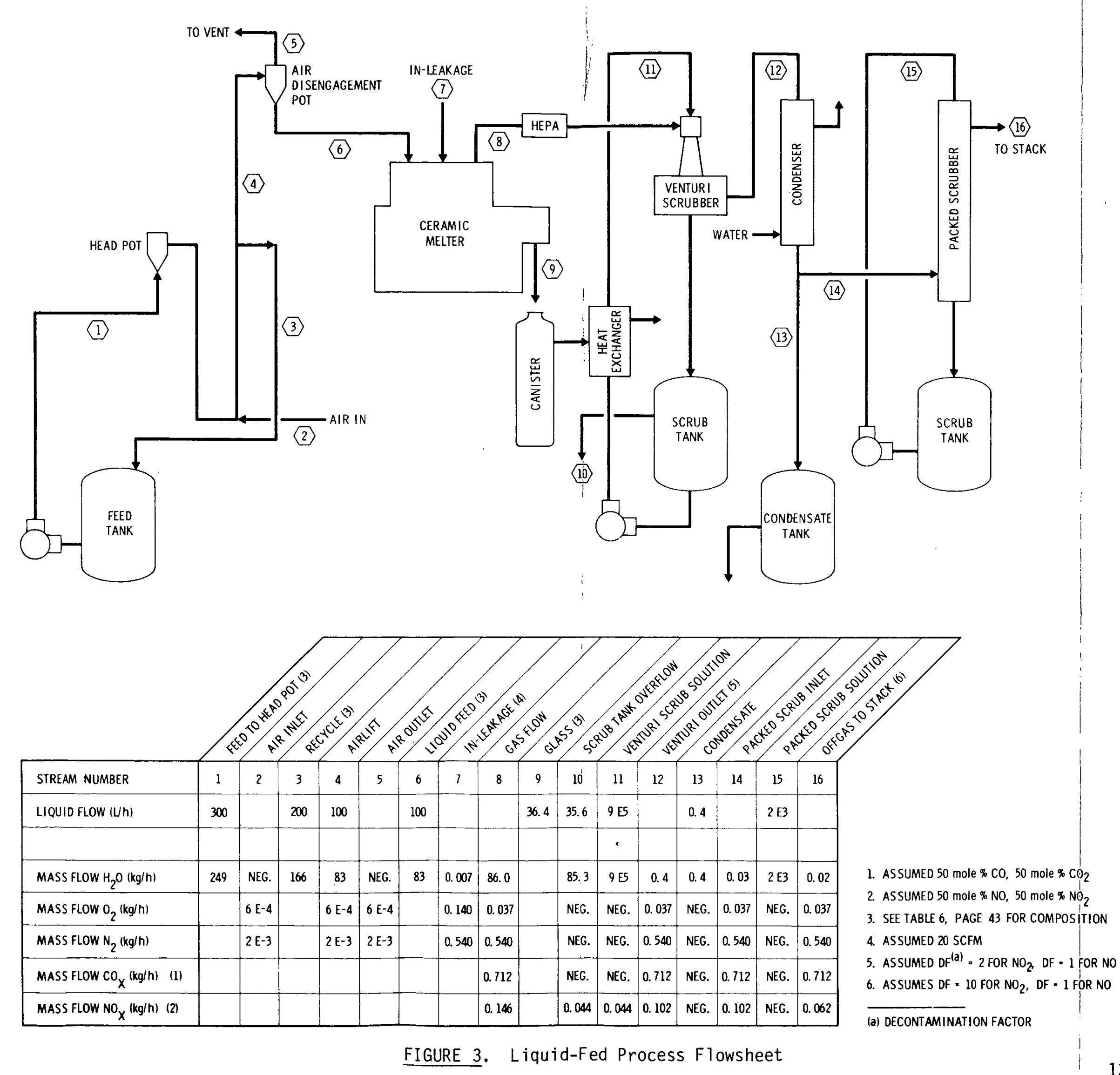

occur. However, research has shown that proper glass development can minimize unstable "cold cap" formation, and that proper offgas system design can accommodate periodic high offgas rates that might occur. Another concern under evaluation is the vapor explosion. This occurs as the result of a very rapid transfer of heat energy to a relatively cold liquid from a liquid substantially above the boiling point of the other liquid (Witte and Cox 1978). In the liquid-fed process, the feed slurry and the molten glass occasionally come in contact. During these periods the potential for a vapor explosion must be evaluated. However, a theoretical study, a literature search of past experimental studies and experience have shown a vapor explosion in the liquid-fed process to be highly improbable, if not impossible (Postma, Chapman and Buelt 1980).

Two different "cold cap" conditions are obtainable: 1) the nonflooded condition--where the feedrate is kept below the maximum capacity of the melter, and the slurry only partially covers the molten glass surface, and 2) the flooded condition--where the melter runs at maximum capacity, and the slurry covers the entire melting surface. Two concerns have been investigated which pertain to operation during flooded conditions: thermal shock to the refractory wall and restriction of crust decomposition gases from leaving the melting surface. Thermal gradients in the refractory during steady-state flooded operation may be steep enough to cause extensive cracking and damage to the refractory. If this is the case, normal operation would be restricted to the nonflooded "cold-cap" condition.

As stated, the second concern pertains to the release path for decomposition gases. In the nonflooded condition the gases from the decomposition of the crust escape around the periphery of the crust. In the flooded condition the decomposition gases vent through the crust. Figure 4 illustrates the resulting localized breakup of the crust when the gases are released in the flooded condition and the momentary contact of the slurry and molten glass. During normal operation, this phenomenon occurs regularly every few minutes and results in a surge in the offgas flow of up to three times normal. Since these surges are predictable, the offgas system is designed to accommodate them. Even in the nonflooded condition, the liquid-fed operation is prone to 


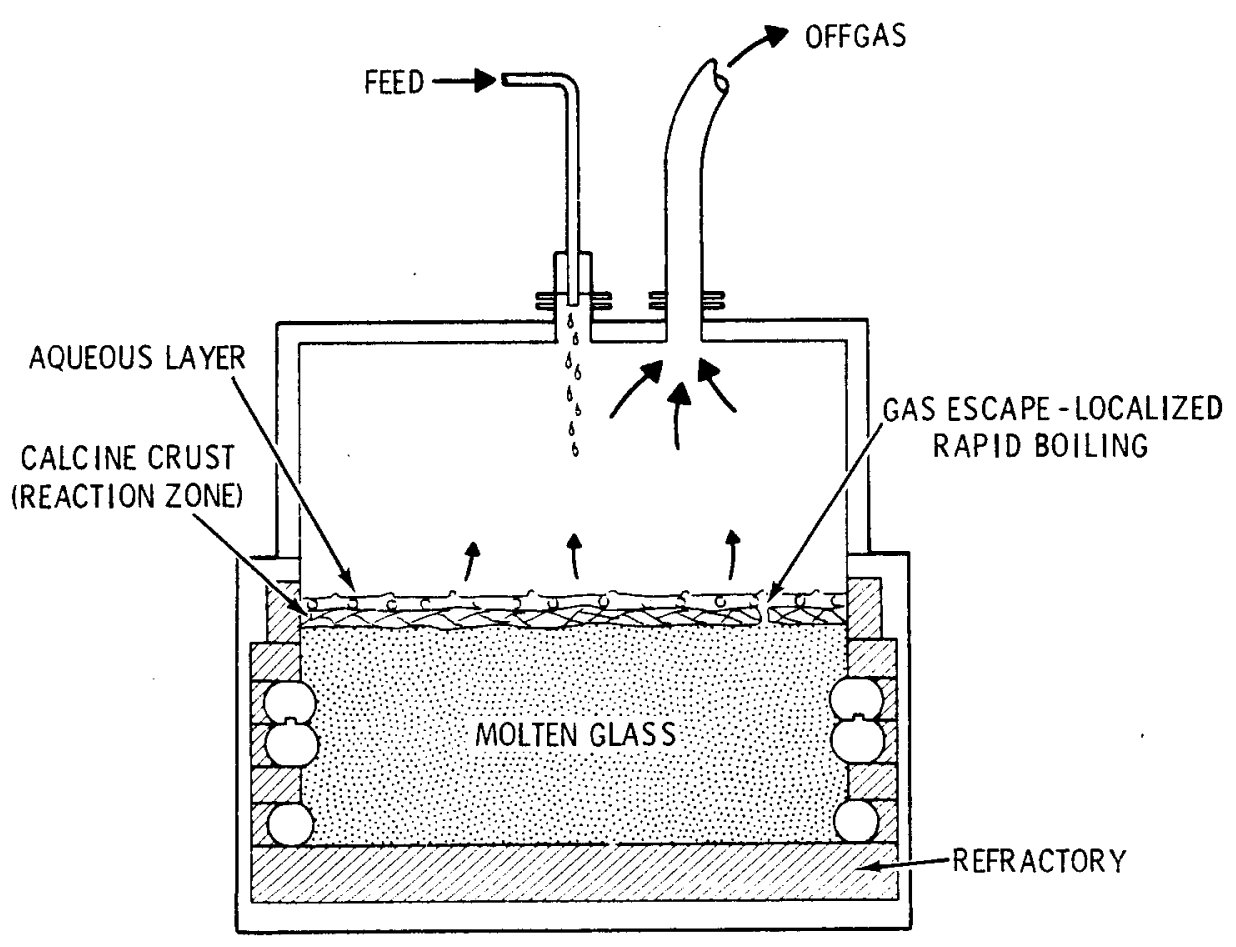

FIGURE 4. Fully Flooded Condition

surges in the offgas flow because the slurry that collects in a bowl of the crust (shown in Figure 5) may spill over the edge onto the molten glass surface, momentarily creating higher than normal boiloff rates. In order to maintain frequent relieving of the offgases through the permeable crust in the flooded condition and to avoid bridging or binding of the "cold cap" to the walls, it is necessary to choose appropriate glass formers and/or glass compositions.

Lower specific production rates with liquid-fed melters compared to calcine fed melters are to be expected because of the considerable amount of additional energy required to evaporate water in the waste slurry. In the liquidfed melter, the available surface area for heat transfer from the molten glass is one factor that limits the slurry evaporation rate. Methods are being investigated at PNL for boosting the capacity of the liquid-fed ceramic melter by providing additional heat to the slurry without increasing the melter size.

Ionic boosters, shown in Figure 6, are one method that has been used to increase the production capacity of liquid-fed melters. The ionic boosters 


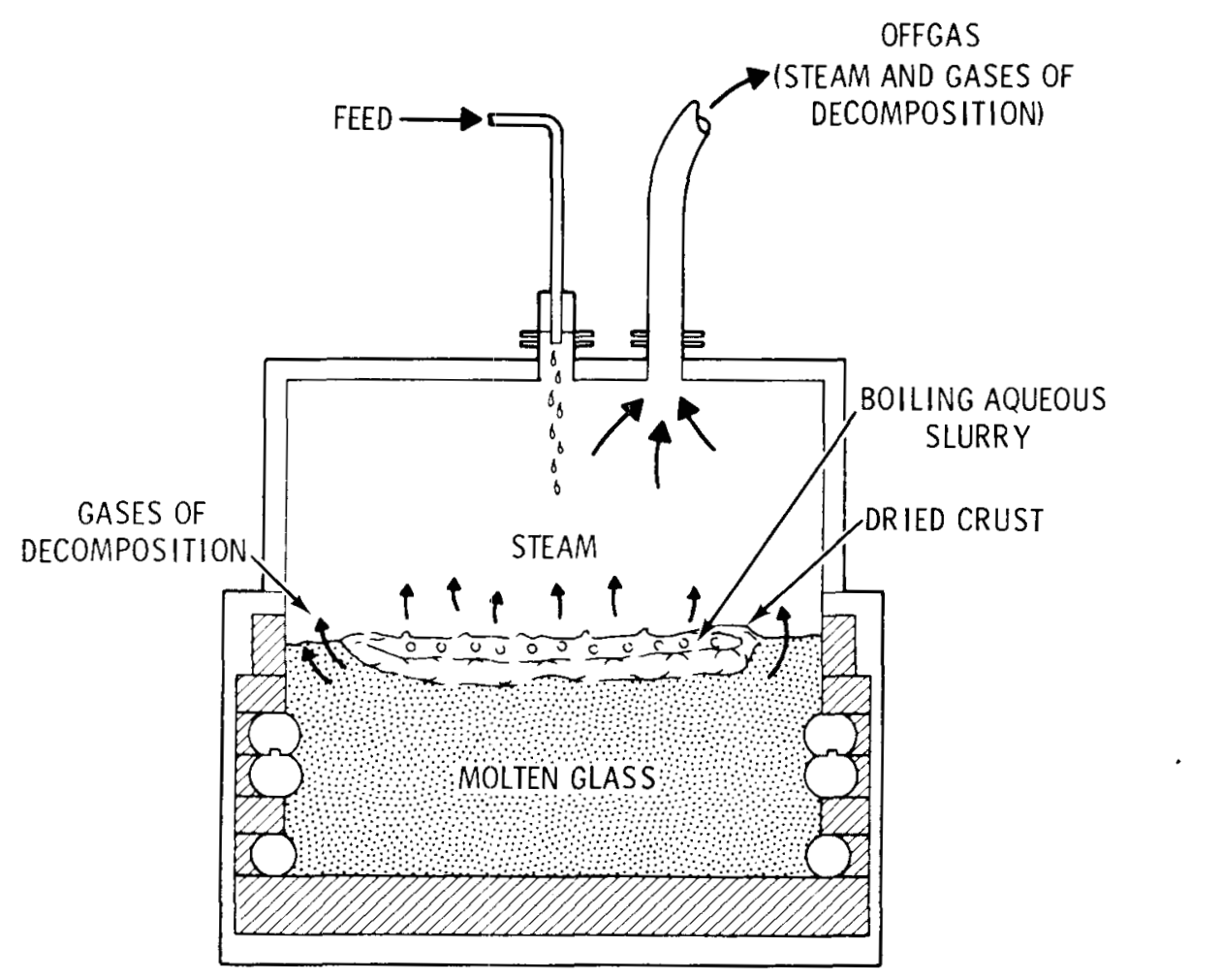

FIGURE 5. Nonflooded Condition

are metal electrodes that are immersed in the slurry pool through which an alternating voltage (in the same electrical phase as the power electrodes) is applied. An electric current passes through the slurry, generating heat directly in the slurry. Ionic boosters have increased the capacity of a me1ter by 50\% (Buelt and Chapman 1979), and higher rates are anticipated. The boosters must be water-cooled to prevent $f i 1 \mathrm{~m}$ boiling at the slurry-electrode interface. Water-cooling also extends booster life by keeping them cool during the idling state when the area above the molten glass is exposed to very high temperatures. I onic boosters, however, can decrease the capacity of the melter up to $25 \%$ if they are left in the melter but not firing, because the water-cooling causes them to act as reflux condensers.

Another boosting method is electric lid heaters (see Figure 6). Lid heaters are used to radiate heat directly to the liquid slurry from above the "cold cap" and to keep the walls free from the feed slurry that splashes up from the melt surface during feeding. 


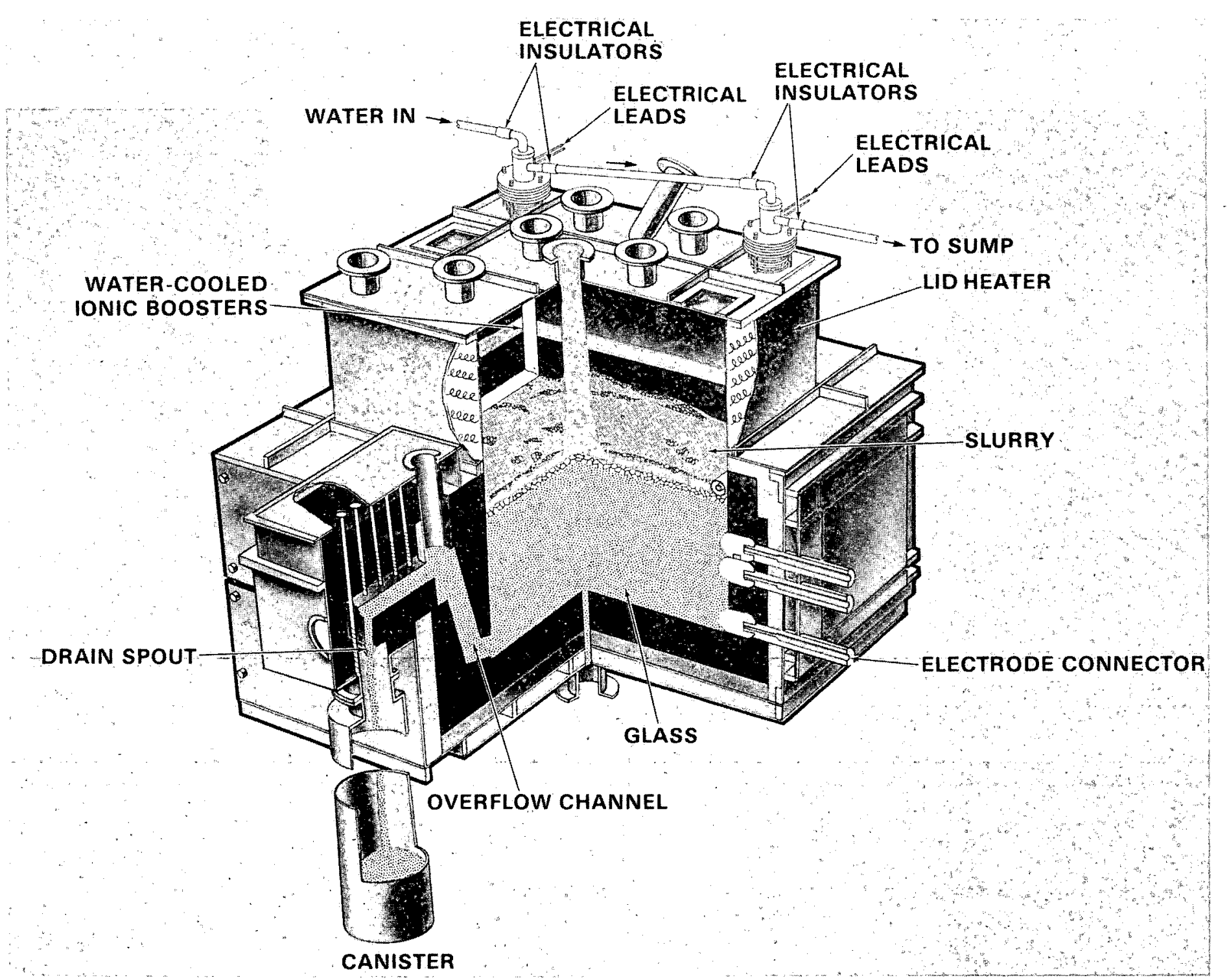

FIGURE 6. LFCM Ionic Boosters 


\section{LABORATORY SCOPING TESTS}

Initial direct liquid-feeding tests of the defense waste chosen for this study began at PNL with a laboratory-scale liquid-feed apparatus (Figure 7).

This apparatus consists of a $25.4-\mathrm{cm} \times 25.4-\mathrm{cm}$ ceramic crucible suspended in a top-loading furnace. The glass level coincides with the top of the furnace so that the heat input is from below the liquid layer as it would be in an actual liquid-fed melter. The purpose of the laboratory-scale scoping tests was to help define the proper batch formulation by evaluating "cold cap" instabilities, foaming, ${ }^{(a)}$ method of offgas release, bridging potential and melting capacity.

Six liquid feeding tests with different batch formulations were completed. Their makeups are shown in Table 1. One weight-percent cornstarch (oxide basis) was added to each batch in Tests 2, 4 and 6 .

During liquid feeding, three layers were found to form. On top is slurry that has dried. Below this is a thin layer of partially reacted solids which have begun to fuse. It is assumed that this layer is where the chemically bonded water, carbonates, nitrates and possibly oxygen from reduction reactions are released. Because of this gas generation, the fused zone tends to be porous. Below the fused zone is the molten glass.

Figure 8 shows the comparison of the "cold cap" and glass products after the power was shut down and the apparatus allowed to rapidly cool. The formulations without cornstarch all foamed, preventing the formation of a stable "cold cap." Therefore, only the tests with cornstarch are shown. The fused zone of $2 \mathrm{~A}$ with premelted frit was less porous than the others, indicating a

(a) Foaming is the release of dissolved or evolved gases from molten glass. Although most melts generate gases, this particular composition creates bubbles that are not easily ruptured; therefore, as the gases are released the number of bubbles increases. Foaming is not desirable because it can reduce the melter capacity, affect the process stability, and in extreme cases may cause equipment damage or shutdown. The proposed mechanisms of foaming as presented by Pye (1979) are discussed in Appendix D. 

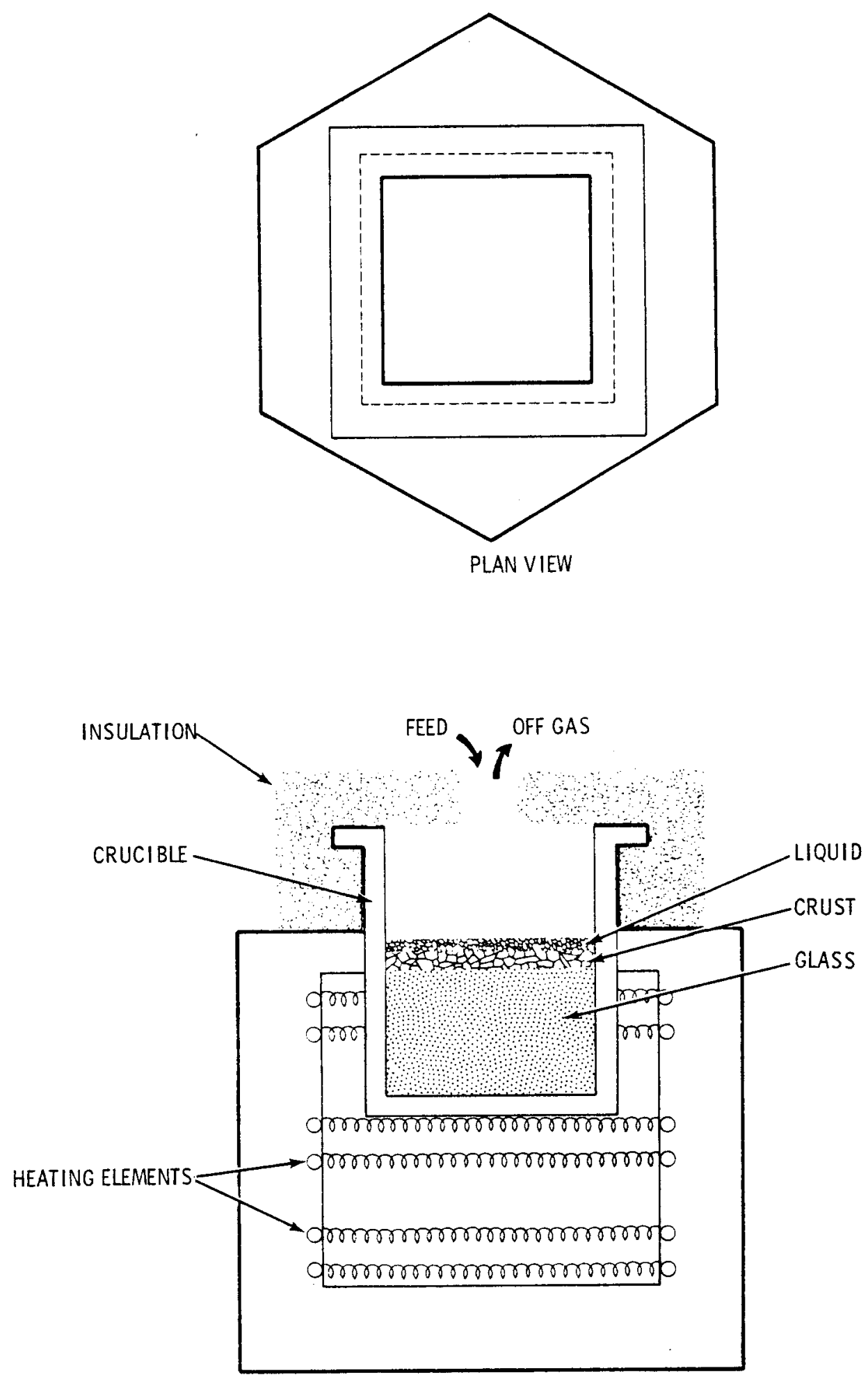

FIGURE 7. Liquid-Feeding Apparatus 
TABLE 1. Batch Formulations for Laboratory Scoping Studies

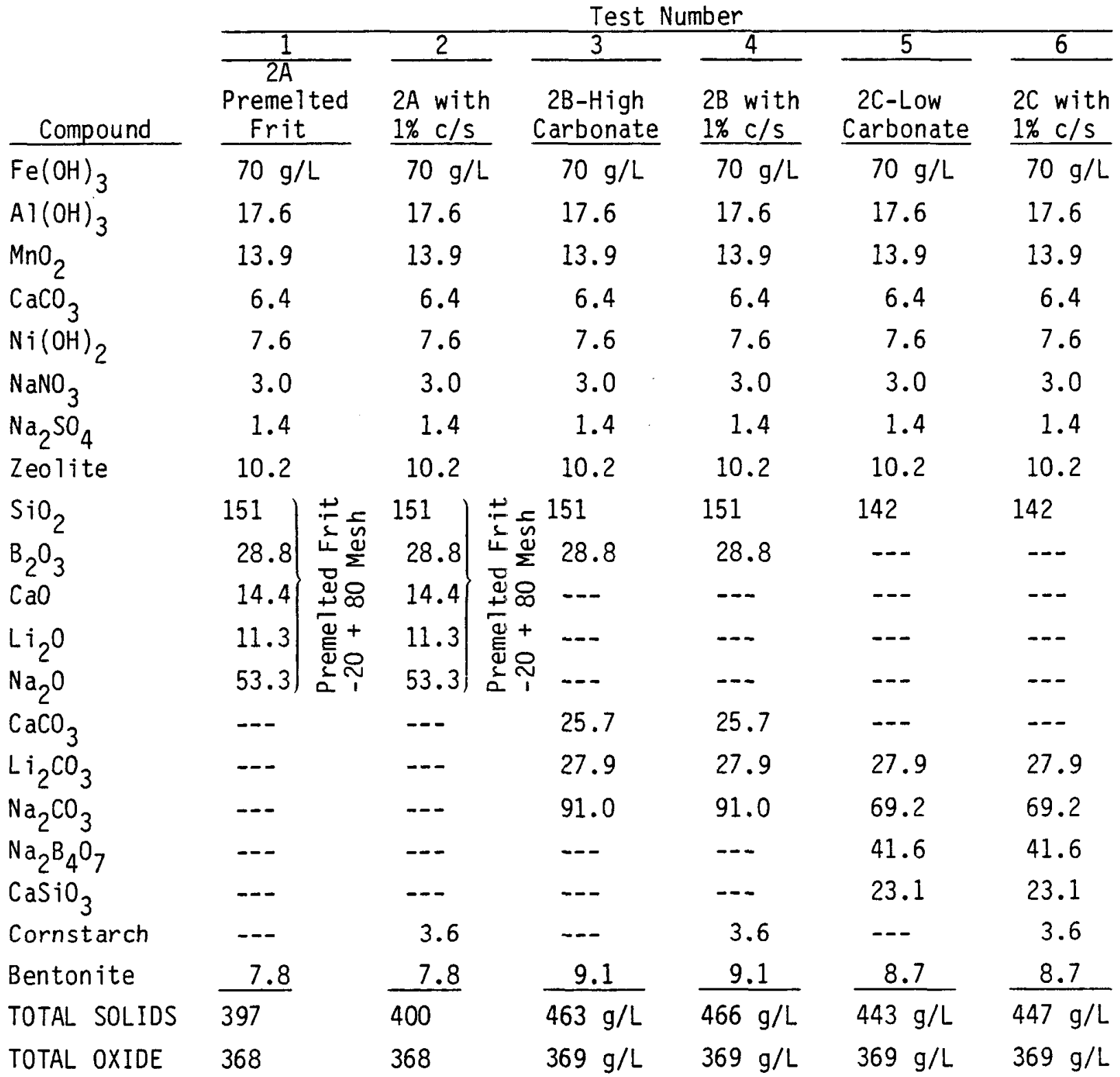

more permeable crust facilitating the escape of decomposition gases. Included in Figure 8 is a sample of the "cold cap" taken during the full-scale LFCM run discussed on page 49.

Figure 9 shows a depiction of the "cold cap" for Runs $2 A$ and $2 B$. Run $2 C$, not shown, was similar to Run $2 B$. In Runs $2 B$ and $2 C$, where minerals replaced 


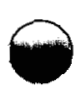

$\Theta$ 

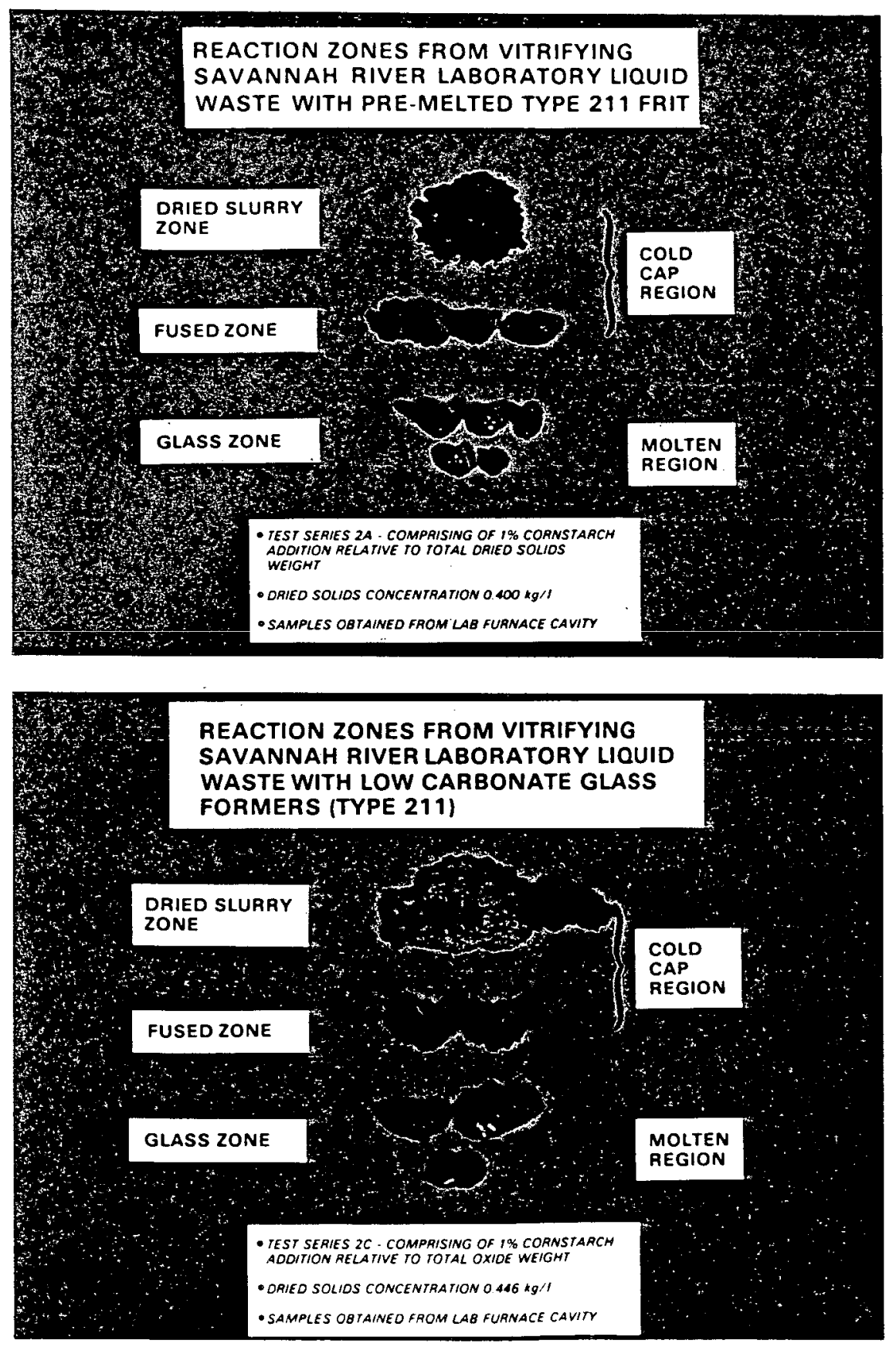
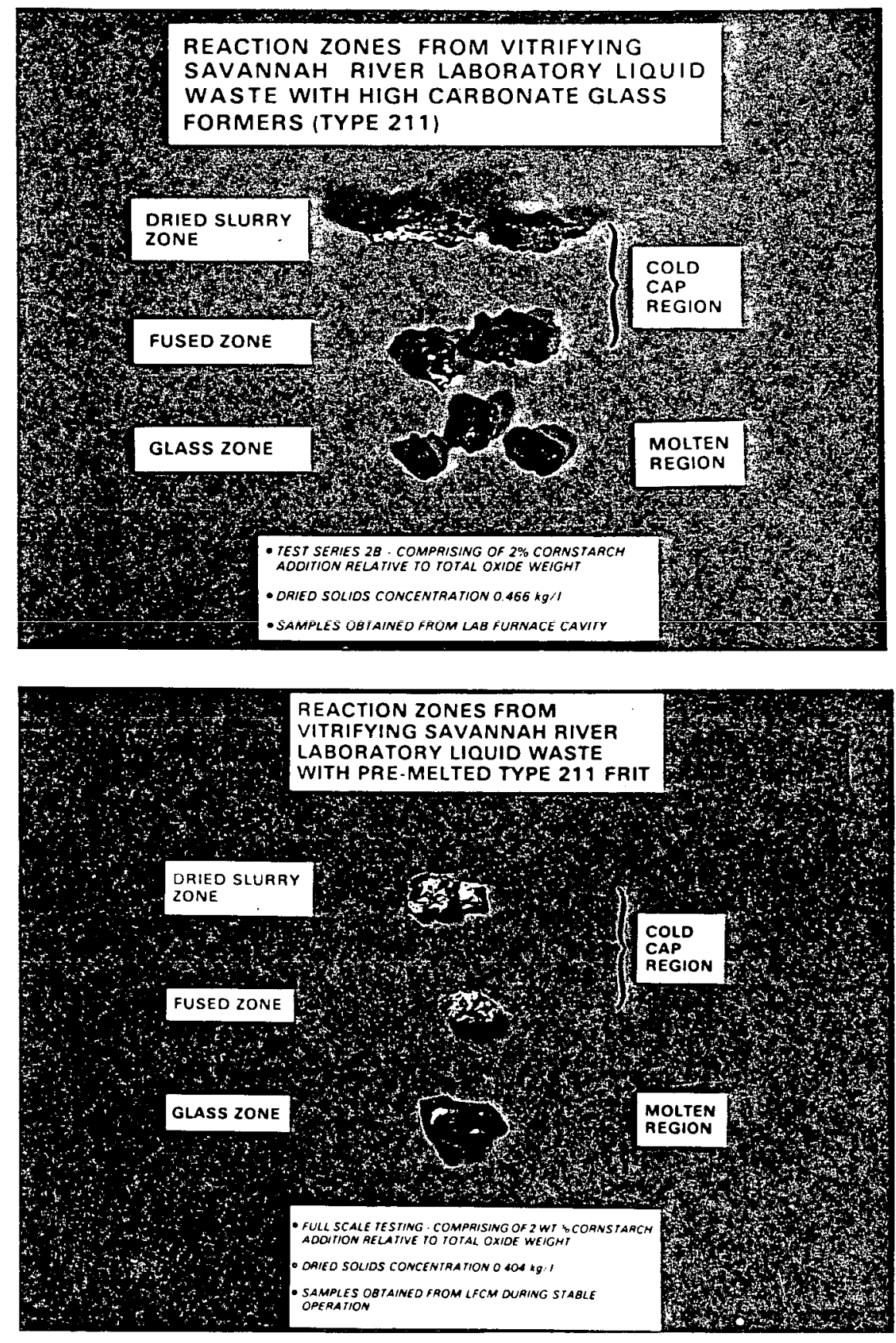

FIGURE 8. "Cold-Cap" Zone Comparisons 

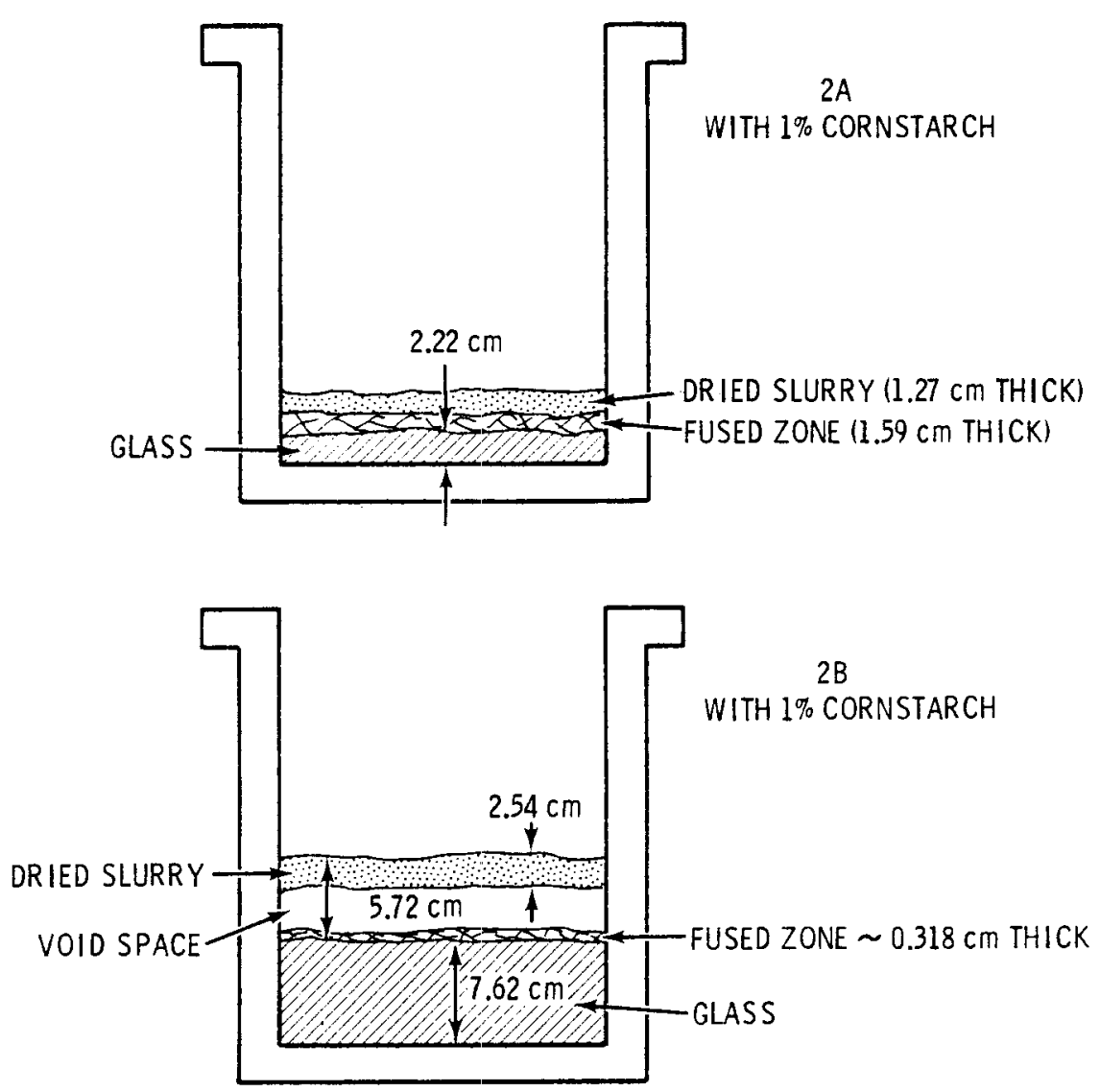

FIGURE 9. "Cold-Cap" Depictions During Runs 2A and 2B

frit, a void space or gas pocket was detected between the fused zone and dried slurry. The formation of this type of void reduces the capacity of the melter due to the reduced heat transfer through the vapor space. It also creates a potentially unstable condition where a collapse of the crust could occur, resulting in a pressurization of the melter or a surge in the offgas system rate and a "cold-cap" disruption. Another finding of the laboratory-scale tests was that a suspending agent was needed in the feed. This was because manganese dioxide, silica and premelted frit tended to settle out. Bentonite, a colloidal alumino-silicate clay was chosen for this. It was added to compose 2 wt\% of the feed (less the $\mathrm{H}_{2} \mathrm{O}$ ). Although bentonite helped substantially, $\mathrm{MnO}_{2}$ still posed a suspension problem. 
The final result of the laboratory-scale testing was that premelted frit, with 1-wt\% cornstarch and 2-wt\% bentonite, was the preferred formulation for follow-up liquid-feeding tests. This choice was based on its low foaming potential, adequate crust porosity and its tendency to form of a stable "cold cap." 


\section{LABORATORY-SCALE CERAMIC-MELTER TEST}

The next stage of testing was with the Experimental Ceramic Melter (ECM) (Figure 10), which is PNI.'s smallest joule-heated melter that allows for rapid testing of processes due to its small size. The ECM's four electrodes are topentering, 5.08-cm-dia, Inconel-690 rods. Two electrodes are located at each end of the melting cavity. Discharge of the glass product is through an overflow system. This can be controlled, if necessary, by adjusting leveling jacks at the four corners of the melter support frame (see flowsheet--Figure 11). Pouring or draining of the melt cavity can also be achieved by use of a platinum airlift tube in the riser section of the melter.

The objectives of the ECM scoping test were to: 1) verify the batch formulation determined in the laboratory-scale experiments, 2) demonstrate processing of the defined batch formulation in a joule-heated ceramic melter, 3 ) determine processing rates, and 4) characterize the offgas for comparison with full-scale tests.

The experimental ceramic-melter scoping test had a duration of $14 \mathrm{~h}$. The average feedrate was $4 \mathrm{~L} / \mathrm{h}$, with the maximum sustained rate of $5-1 / 2 \mathrm{~L} / \mathrm{h}$ maintained for the final $3 \mathrm{~h}$ of the run. This feedrate is equivalent to $2100 \mathrm{~L} / \mathrm{h}$ in the liquid-fed melter used for the full-scale testing that follows. The feed composition for the run was that defined as the most favorable formulation (see Table 2) by the lab scoping tests. The particle size of the premelted frit used is shown in Table 3.

The run was completed with only minor difficulties. Control of the feedrate was difficult because the feed system was inadequate for this type of slurry. To avoid settling in the feed line, it was necessary to operate the slurry feed pump at a high rate, greater than the melter's capacity. This made it difficult to establish a steady feed rate. Foaming did not occur during periods of normal feeding; however, foam was observed after overfeeding had occurred. It is believed that the foam was caused by the low glass temperature caused by overfeeding. 


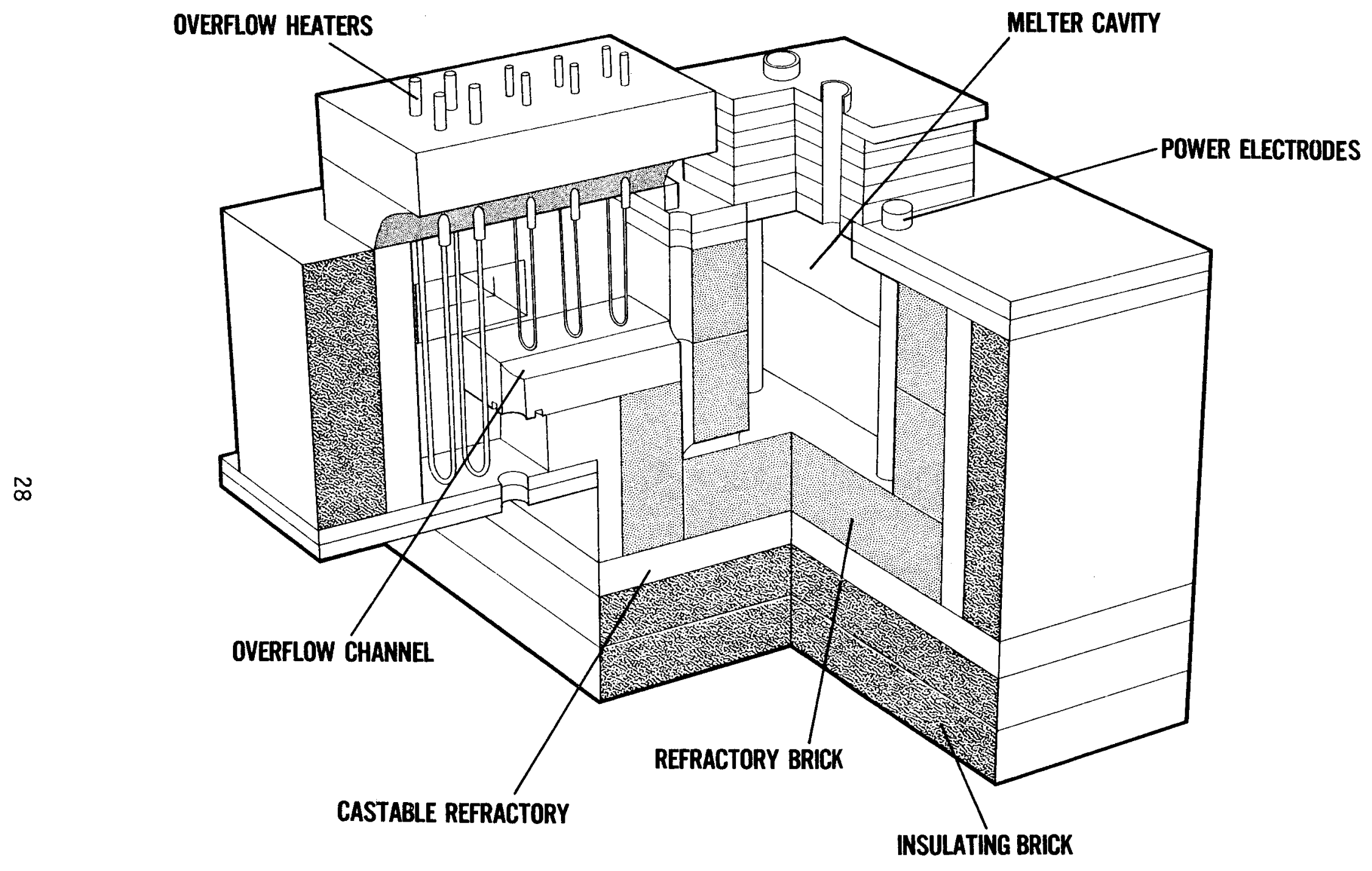

FIGURE 10. Experimental Ceramic Melter 


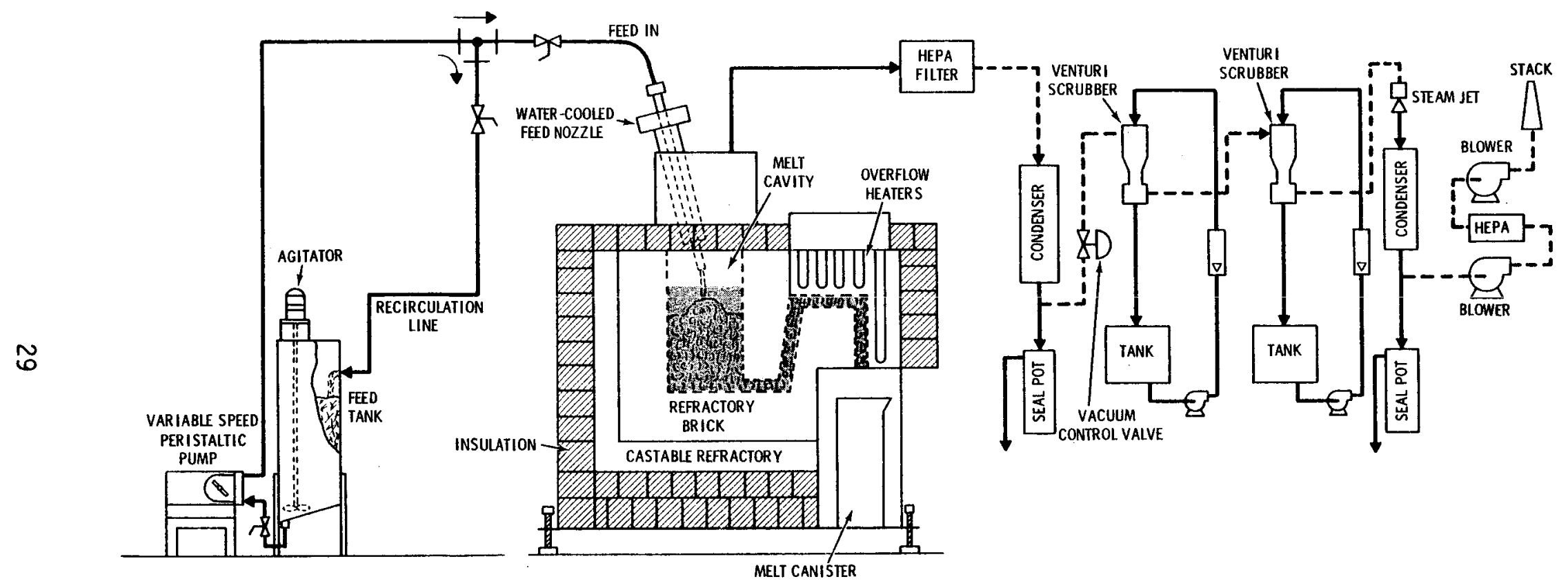

FIGURE 11. Liquid-Feed Control Loop 
TABLE 2. Feed and Product Makeup for ECM Liquid-Fed Run

\begin{tabular}{|c|c|c|c|c|}
\hline \multicolumn{2}{|c|}{ Composition of Feed } & \multicolumn{3}{|c|}{ Composition of Product } \\
\hline \multirow[b]{2}{*}{ Compound } & \multirow{2}{*}{$\begin{array}{c}\text { Concentration, } \\
\mathrm{g} / \mathrm{L} \\
\end{array}$} & \multirow{3}{*}{ Compound } & \multirow{3}{*}{$\begin{array}{l}\text { Conce } \\
\mathrm{g} / \mathrm{L} \\
\end{array}$} & \multirow{3}{*}{ wt\% } \\
\hline & & & & \\
\hline \multicolumn{2}{|l|}{ Waste } & & & \\
\hline $\mathrm{Fe}(\mathrm{OH})_{3}$ & 70.0 & $\mathrm{Fe}_{2} \mathrm{O}_{3}$ & 52.3 & 14.4 \\
\hline $\mathrm{A} 1(\mathrm{OH})_{3}$ & 17.6 & $\mathrm{Al}_{2} \mathrm{O}_{3}$ & 11.5 & 3.17 \\
\hline $\mathrm{MnO}_{2}$ & 14.0 & $\mathrm{MnO}_{2}$ & 14.0 & 3.86 \\
\hline $\mathrm{Ni}(\mathrm{OH})_{2}$ & 7.6 & $\mathrm{NiO}$ & 6.12 & 1.69 \\
\hline $\mathrm{CaCO}_{3}{ }^{2}$ & 6.4 & $\mathrm{CaO}$ & 3.59 & 0.99 \\
\hline $\mathrm{NaNO}_{3}$ & 3.0 & $\mathrm{Na}_{2} \mathrm{O}$ & 1.09 & 0.30 \\
\hline $\mathrm{Na}_{2} \mathrm{SO}_{4}$ & 1.4 & $\mathrm{Na}_{2} \mathrm{SO}_{4}$ & 1.40 & 0.39 \\
\hline Zeolite $(a)$ & 10.4 & $\mathrm{SiO}_{2}$ & 4.99 & 1.37 \\
\hline & & $\mathrm{Al}_{2} \mathrm{O}_{3}$ & 1.93 & 0.53 \\
\hline & & $\mathrm{CaO}$ & 1.06 & 0.29 \\
\hline & & $\mathrm{Na}_{2} \mathrm{O}$ & 0.43 & 0.12 \\
\hline
\end{tabular}

Additives

wt\%

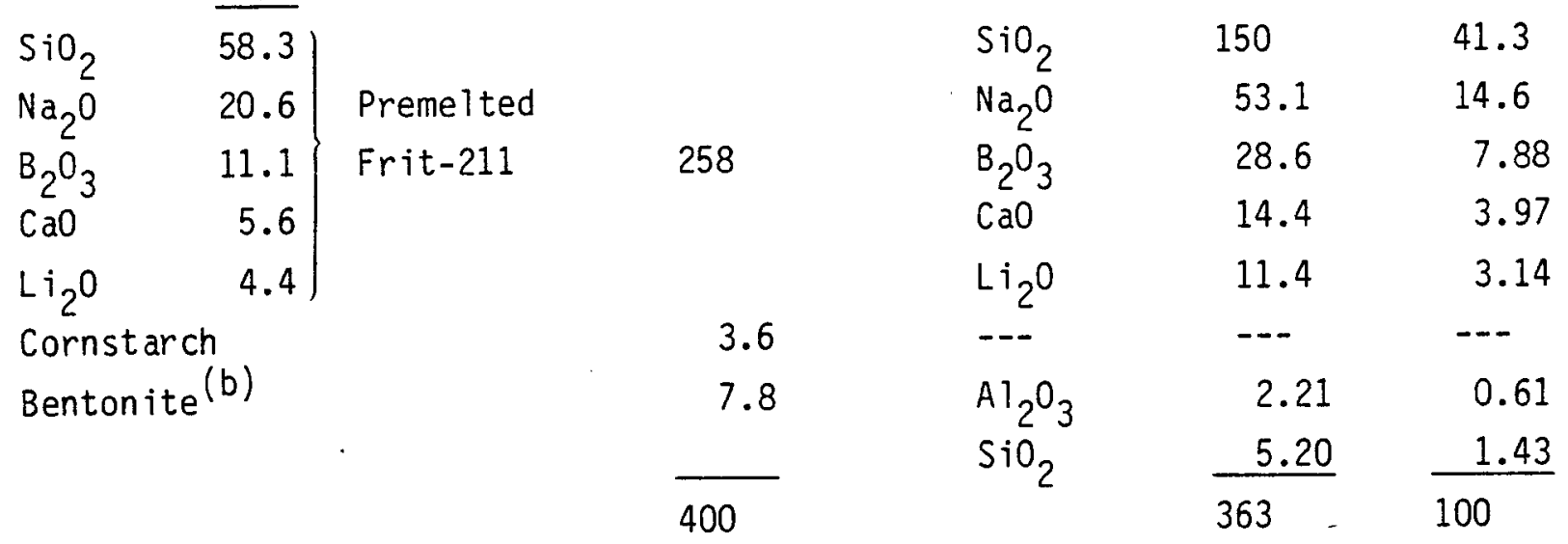

(a) Linde Ion Siv IE- $95,80 \% \mathrm{CaAl}_{2} \mathrm{Si}_{4} \mathrm{O}_{12} \cdot 6 \mathrm{H}_{2} \mathrm{O}, 20 \% \mathrm{Na}_{4} \mathrm{Ca}_{1} \cdot{ }_{5} \mathrm{Al}_{3} \mathrm{Si}_{8} \mathrm{O}_{24} \cdot 7 \mathrm{H}_{2} \mathrm{O}$

(b) Alumino-silicate clay assumed to be $\mathrm{Al}_{2} \mathrm{O}_{3} \cdot 4 \mathrm{SiO}_{2} \cdot \mathrm{H}_{2} \mathrm{O}$. 
TABLE 3. Particle Size of Frit-211 for ECM LiquidFeeding Tests

$\begin{array}{rrrr}\frac{\text { Mesh Size }}{\leq 28} & & \text { wt\% } \\ 32 & & 0.43 \\ 48 & & 8.96 \\ 65 & & 45.8 \\ 100 & & 20.5 \\ \geq 100 & & 13.9 \\ & & 10.4 \\ & & & 100\end{array}$

Figure 12A shows three feeding periods during the run. Feed Period 1 ended due to overfeeding as a result of insufficient electrode power. Period 2 was interrupted to allow the excess liquid, caused by overfeeding, to evaporate. This period was terminated due to higher-than-desired melter temperatures. Venting through the "cold cap" was present during Period 2 when a flooded condition existed. The last period was a stable one with a well-formed "cold cap." The average feedrate during Period 3 was $5-1 / 2 \mathrm{~L} / \mathrm{h}$ at $7-1 / 2$ to $8 \mathrm{~kW}$. No sign of venting from below the "cold cap" was noted during this period.

The measured temperature of the electrodes was maintained between $850^{\circ}$ and $950^{\circ} \mathrm{C}$ (Figure $12 \mathrm{~B}$ ). This temperature does not indicate the maximum temperature of the electrode due to the location of the thermocouple. Tests have shown the maximum electrode temperature $2100^{\circ} \mathrm{C}$ higher. At this setting, glass temperatures, as shown in Figure 13 , ranged from $1050^{\circ}$ to $1150^{\circ} \mathrm{C}$.

Chemical analyses of the glass samples taken during the run are shown in Table 4. Twenty and four-tenths kilograms of glass was collected during the run. All of the glass had very close to the desired composition. No evidence of metallic precipitation was seen. Metallic precipitation is caused by excessive levels of reducing agents in the feed and may be detected by substantially lowered NiO levels in the glass as seen in previous tests when glasses were melted with excessive reducing agents. 

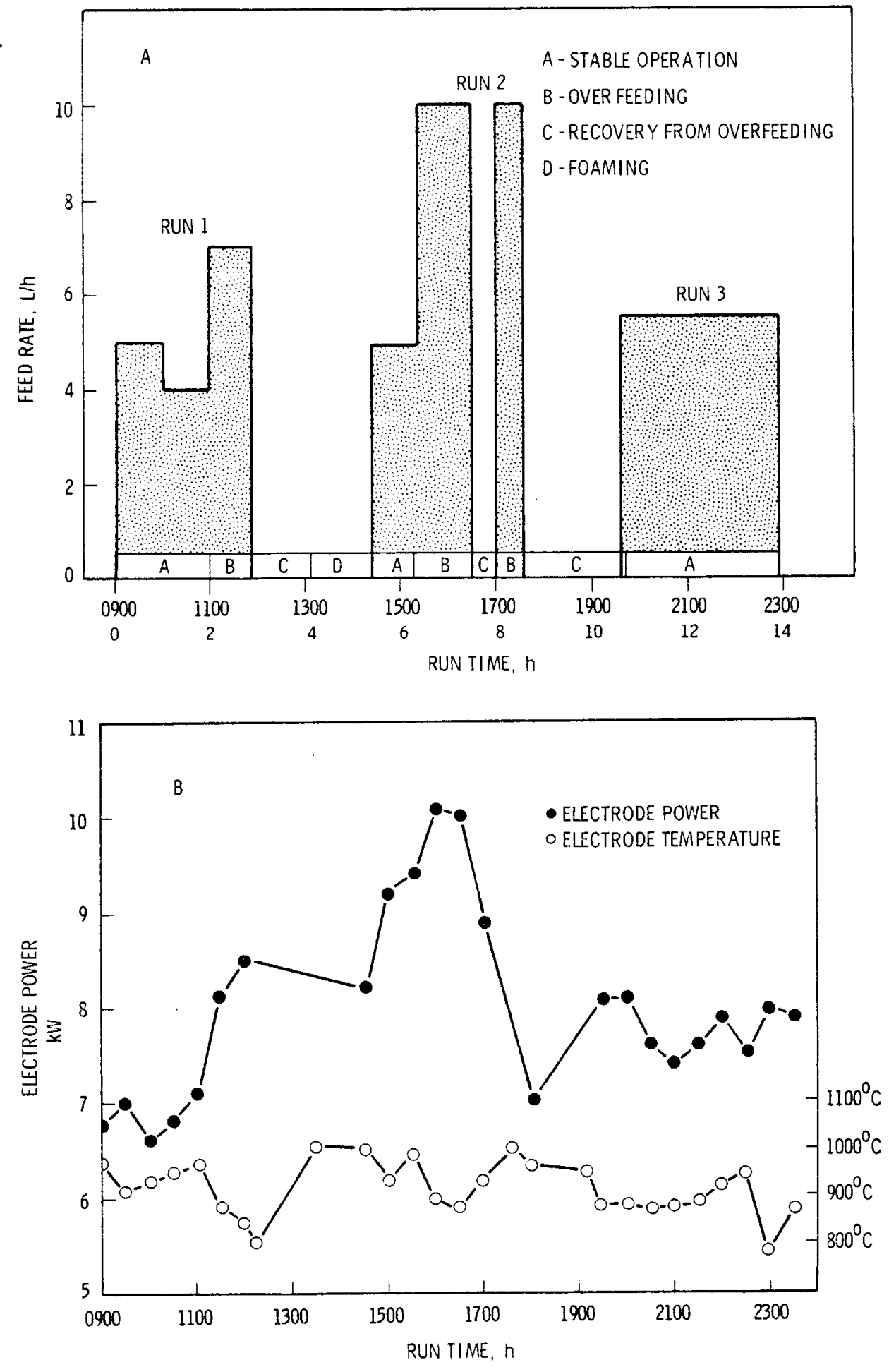

FIGURE 12A,B. ECM-79-2 Liquid-Fed Run Feed Schedule 


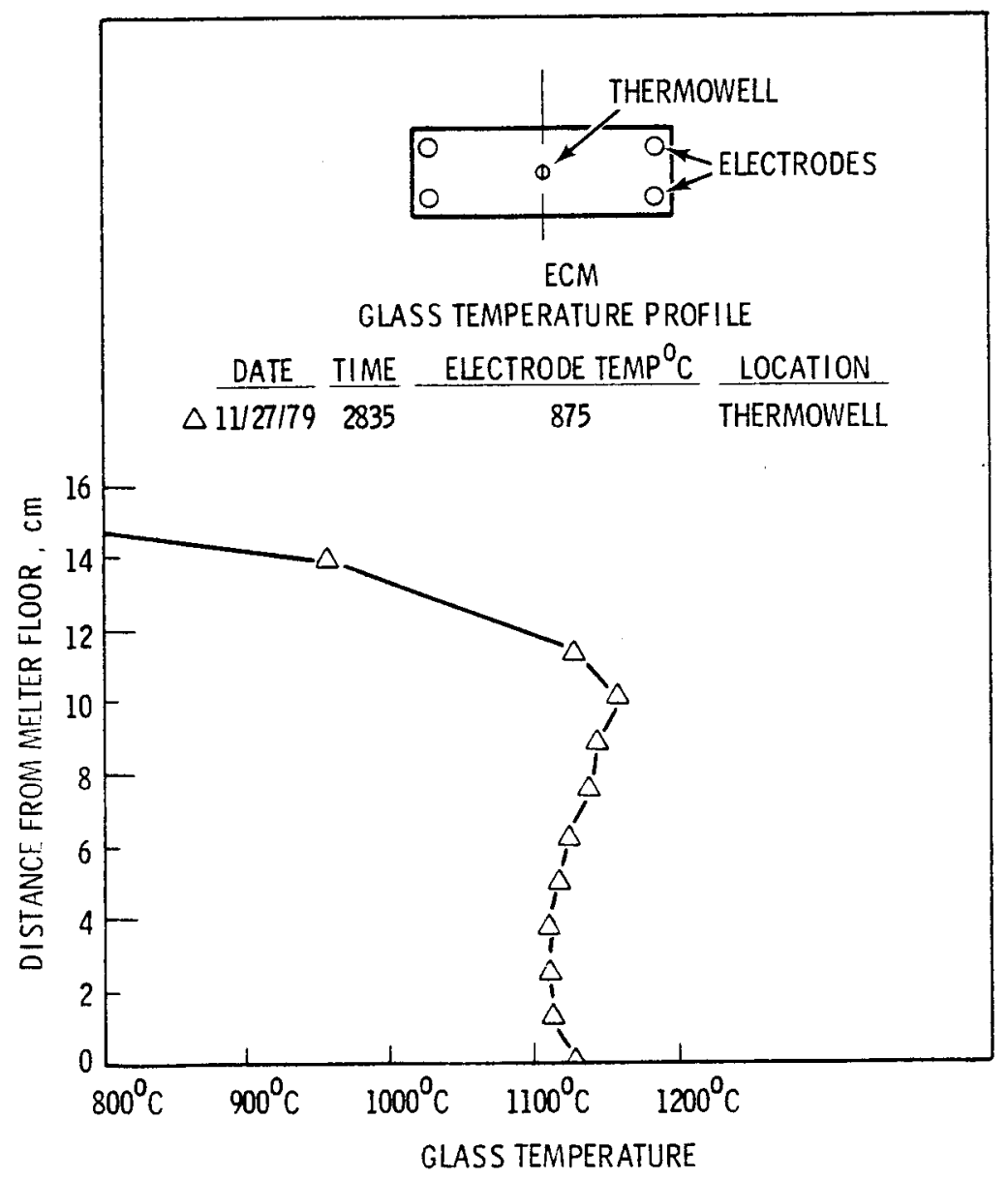

FIGURE 13. ECM-79-2 Temperature Profiles 
TABLE 4. ECM Glass Samples

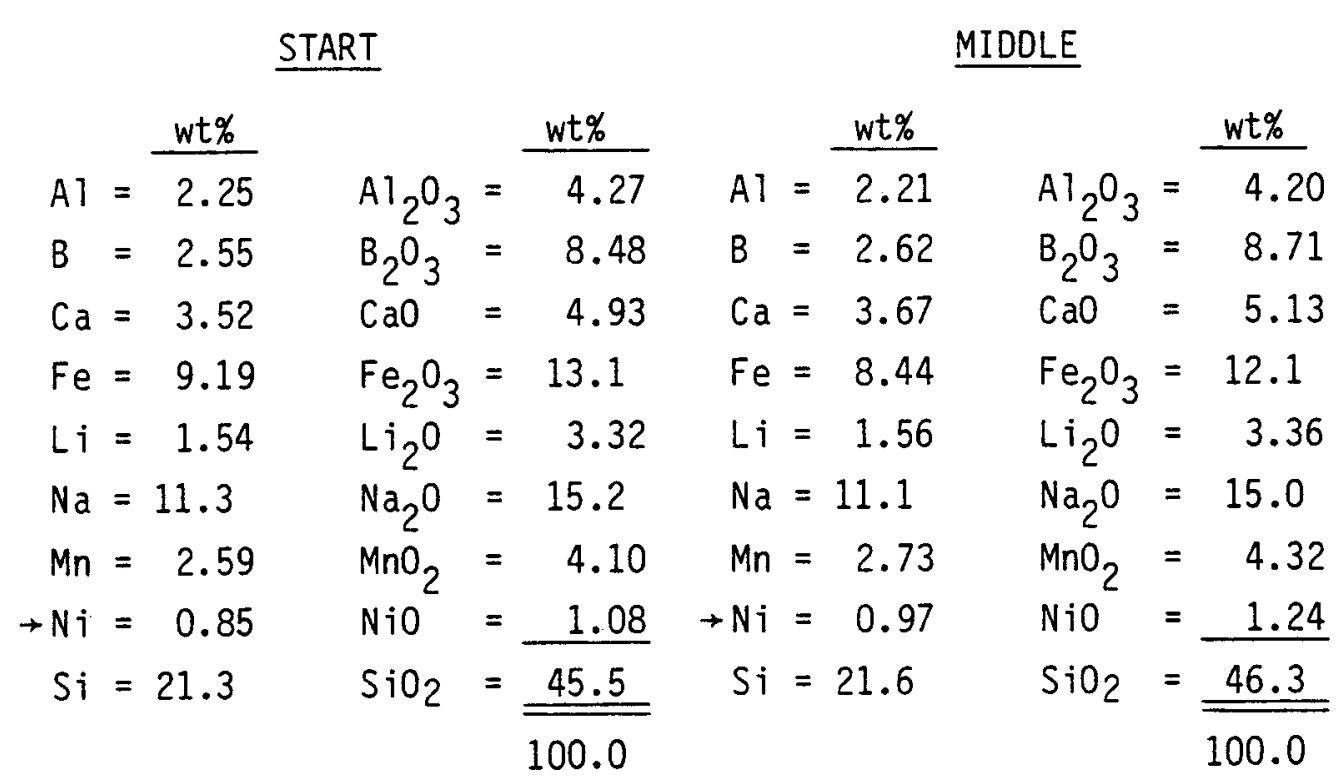

END

$$
\begin{aligned}
& A 1=\frac{w t \%}{2.20} \quad \mathrm{Al}_{2} \mathrm{O}_{3}=\frac{w t \%}{4.16} \\
& B=2.65 \quad B_{2} O_{3}=8.80 \\
& \mathrm{Ca}=3.72 \quad \mathrm{CaO}=5.20 \\
& \mathrm{Fe}=8.20 \quad \mathrm{Fe}_{2} \mathrm{O}_{3}=11.7 \\
& \mathrm{Li}=1.53 \quad \mathrm{Li}_{2}{ }^{\mathrm{O}}=3.30 \\
& \mathrm{Na}=10.9 \quad \mathrm{Na}_{2} \mathrm{O}=14.7 \\
& \mathrm{Mn}=2.65 \quad \mathrm{MnO}_{2}=4.20 \\
& \rightarrow \mathrm{Ni}=1.05 \quad \mathrm{Ni0}=1.34 \\
& \mathrm{Si}=21.5 \quad \mathrm{SiO}_{2}=\frac{46.0}{\overline{99.4}}
\end{aligned}
$$




\section{FULL-SCALE CERAMIC-MELTER TESTS}

The LFCM system shown in Figure 14 provides a near full-scale test facility. This equipment is described in detail in another report (Buelt and Chapman 1978).

Simulated waste sludge and glass formers are combined in a feed makeup tank. Batches of feed are periodically transferred to a heated feed holding tank and then pumped to an airlift system for metering, followed by gravity feeding to the melter. The drying and melting of the feed slurry that occurs in the melter releases steam and decomposition gases that are treated in an offgas system. Aerosols and particulates are filtered, and gases are condensed and scrubbed. Noncondensables are exhausted to the atmosphere. The waste glass flows continuously into a receiving canister.

The objectives of the full-scale scoping test were to: 1) evaluate and characterize the direct liquid-feed processing of a defense-waste glass, 2) evaluate product quality, 3) characterize and quantify the offgas, 4) determine modification required in the equipment for continuous long-term operation, and 5) identify any further laboratory work needed to improve the feed formulation.

\section{EQUIPMENT OPERATION}

The test was completed during January 1980. It iasted $65.5 \mathrm{~h}$ and consisted of seven periods of continuous feeding. The actual feeding time totaled 44-1/4 h. A summary of the test is shown in Table 5. The feedrates and glass temperatures, tank resistance and power, and electrode temperatures for the test are plotted in Figures 15,16 and 17 , respectively. The average feedrate for the seven feed periods was $66 \mathrm{~L} / \mathrm{h}$, and the overall average for the run was $45 \mathrm{~L} / \mathrm{h}$. Approximately $2900 \mathrm{~L}$ of simulated waste slurry was processed, generating $>1050 \mathrm{~kg}$ of glass.

The feed material was a mixture of -200 mesh premelted frit and simulated defense-waste sludge in a ratio of $72-w t \%$ frit to $28-w t \%$ waste oxides. Two 


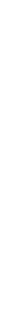




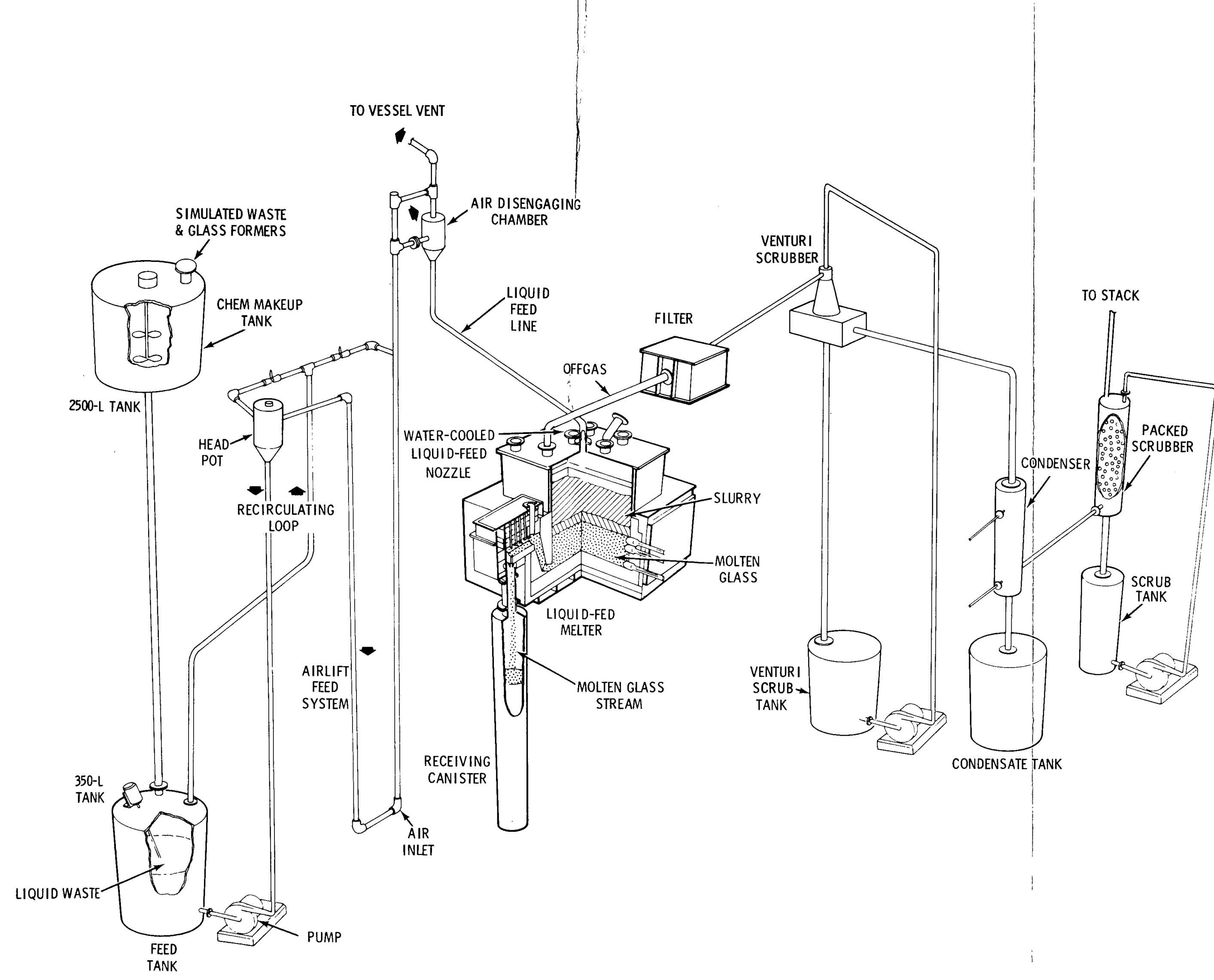

FIGURE 14. Liquid-Fed Process 

TABLE 5. Continuous LFCM Feed Periods

\begin{tabular}{|c|c|c|c|c|c|c|}
\hline Period & Time & Date & $\begin{array}{l}\text { Total } \\
\text { Feed ing } \\
\text { Time, } h \\
\end{array}$ & $\begin{array}{l}\text { Total } \\
\text { Liters } \\
\text { Fed, L } \\
\end{array}$ & $\begin{array}{l}\text { Average } \\
\text { Feedrate, } \\
L / h\end{array}$ & $\begin{array}{l}\text { Reason for } \\
\text { Termination }\end{array}$ \\
\hline 1 & $2130-0539$ & $1 / 14,15 / 80$ & 8.15 & 371.2 & 45.5 & Feed-Line Plug \\
\hline 2 & $0557-1345$ & $1 / 15 / 80$ & 7.8 & 459 & 58.8 & Foaming \\
\hline 3 & $2130-0516$ & $1 / 15,16 / 80$ & 7.76 & 568.7 & 73.3 & Foaming \\
\hline 4 & $1254-1435$ & $1 / 16 / 80$ & 1.68 & 62.4 & 37.1 & Feed-Line Plug \\
\hline 5 & $1602-1720$ & $1 / 16 / 80$ & 1.3 & 64 & 49.2 & $\begin{array}{l}\text { Feed Nozzle } \\
\text { Plug }\end{array}$ \\
\hline 6 & $2000-1030$ & $1 / 16,17 / 80$ & 14.55 & 1197 & 82.3 & Overfeeding \\
\hline 7 & $1200-1500$ & $1 / 17 / 80$ & 3.0 & 216 & 71.9 & End of Run \\
\hline FOTAL & & & 44.24 & 2940 & 66 & \\
\hline
\end{tabular}

weight-percent bentonite was added as a suspending agent. The feed makeup, presented in Table 6 , was the same as that used in the ECM tests, except that the frit size was finer. Also, tracer elements were added for volatility studies. These included $\mathrm{Ru}, \mathrm{Sb}, \mathrm{Te}, \mathrm{CS}$ and $\mathrm{S}$, which were present in the amounts expected to be in the actual waste; Sb was added to 100 times the expected amount for detection purposes. Two different cornstarch levels were used in the slurry. In the first three feed periods, 1-wt\% cornstarch was added. During the last four, 2 wt\% was present. Each of the feed periods is described below.

Feed Periods 1 and 2

Periods 1 and 2 are discussed together as the downtime between them amounted to only $18 \mathrm{~min}$ during which much of the "cold cap" remained. Glass foaming was a major problem during both Periods 1 and 2 .

Foaming began shortly after the feeding started. The feedrate was reduced and the foaming stopped within $1 \mathrm{~h}$. This foaming very likely resulted from precombustion of the cornstarch due to high temperatures at startup. Combustion would have reduced the amount of cornstarch available for foaming control. When, later in the run, the cornstarch loading of the feed was doubled, no foaming occurred. 


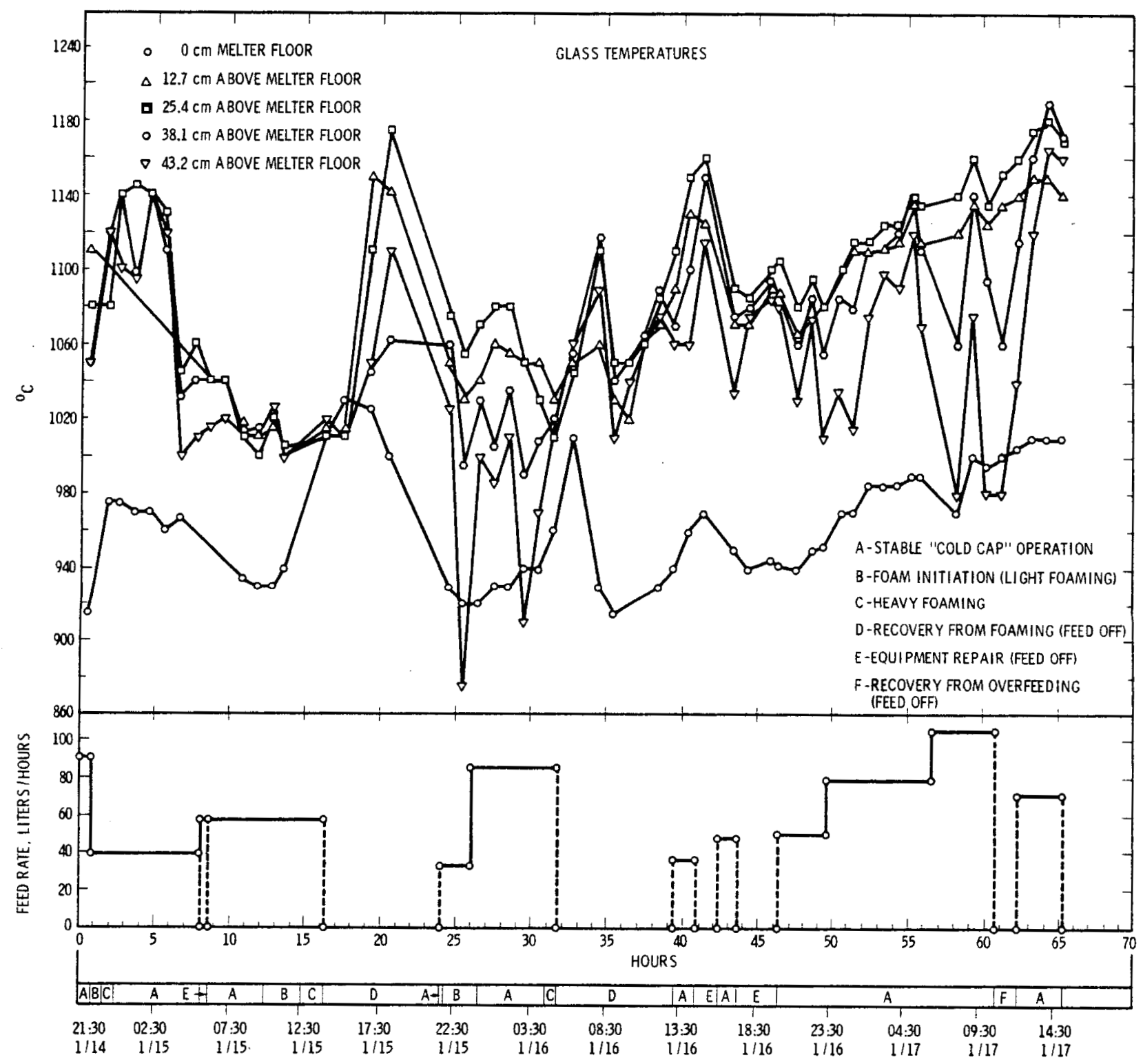

FIGURE 15. LFCM Glass Temperatures and Feed Schedule

This foaming was unlikely caused by the release of oxygen (reboil) from the melt during the initial heatup since prior to the test, steps to reduce reboil potential were taken. These included rapid heatup of the melt to release the gases that come off during reboil. Also, a nitrogen purge was used in the vapor space above the melt to reduce the readsorption of the oxygen when the melt was returned to the idling temperature. 


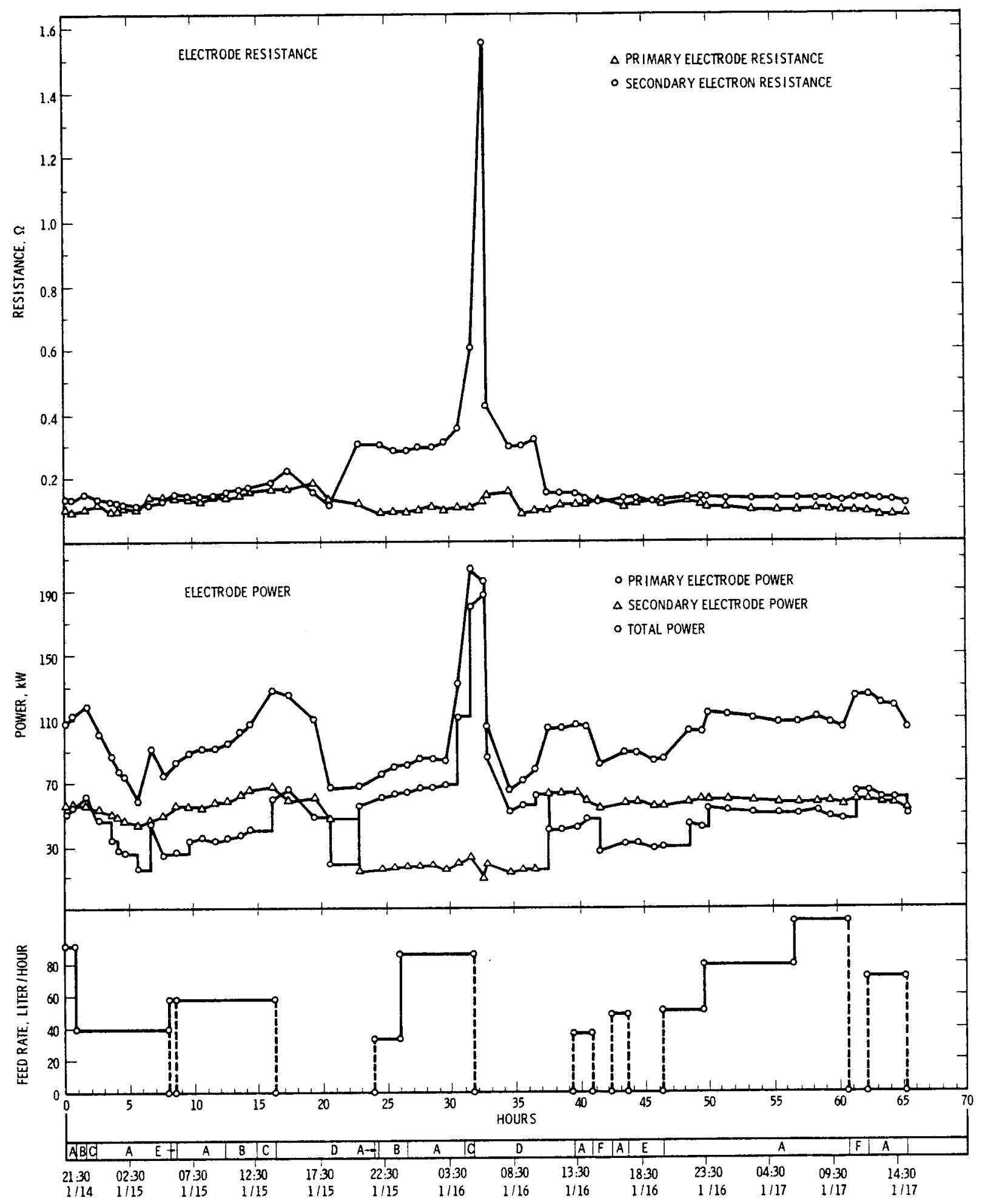

FIGURE 16. Electrode Power and Resistance 


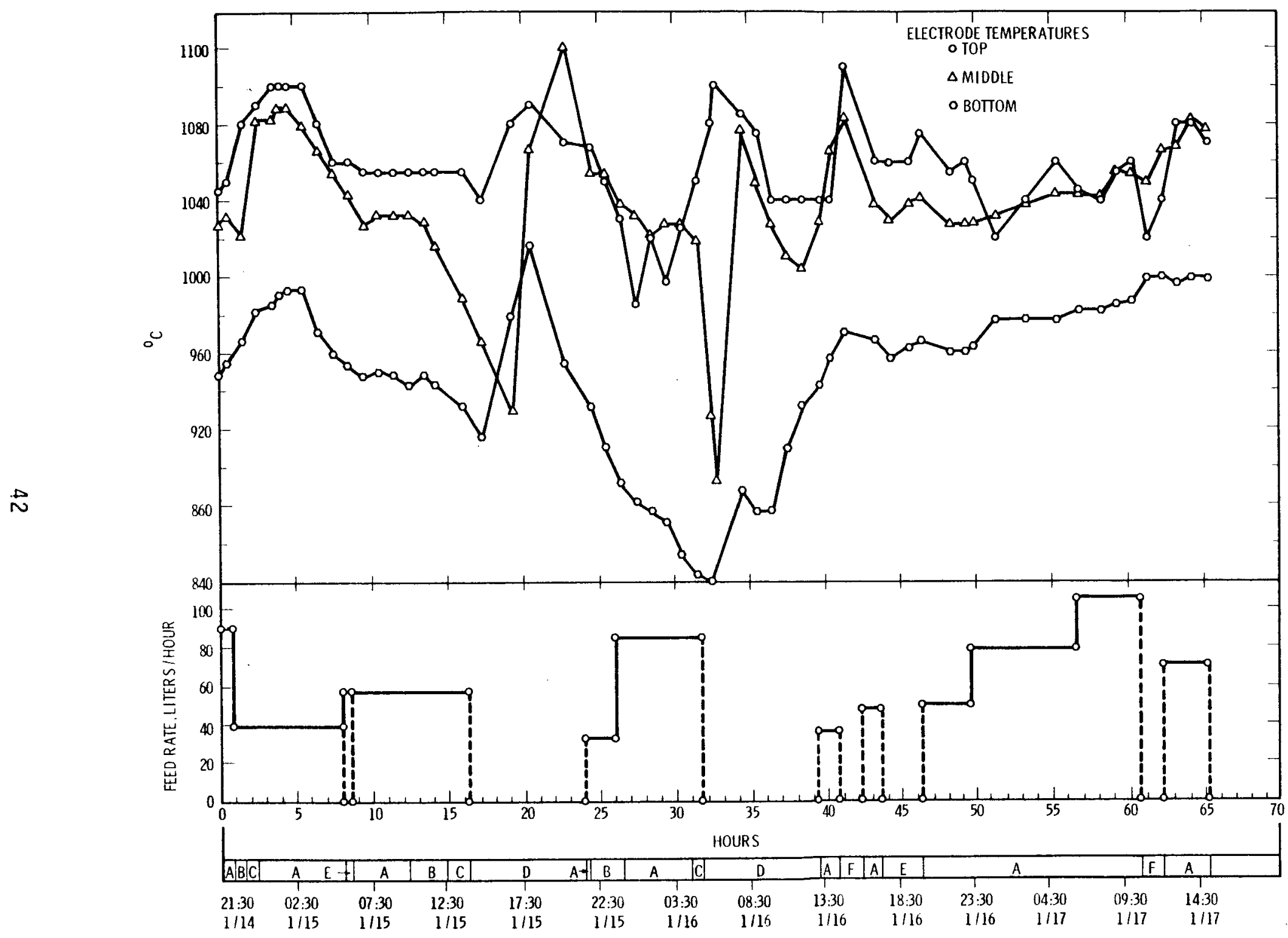

FIGURE 17. LFCM Electrode Temperatures 
TABLE 6. Feed and Product Makeup for LFCM Liquid-Fed Run

\section{Composition of Feed}

Compound
Concentration, $\mathrm{g} / \mathrm{L}$

70.0

17.5

14.0

7.5

6.4

2.9

1.4

10.4

Zeolite $\mathrm{Na}_{2} \mathrm{SO}_{4}$
Composition of Product

Compound $\frac{\text { Concentration }}{\mathrm{g} / \mathrm{L} \quad \text { wt\% }}$

$\mathrm{Fe}_{2} \mathrm{O}_{3}$

$\mathrm{Al}_{2} \mathrm{O}_{3}$

$\mathrm{MnO}_{2}$

$\mathrm{NiO}$

$\mathrm{CaO}$

$\mathrm{Na}_{2} \mathrm{O}$

$\mathrm{Na}_{2} \mathrm{SO}_{4}$

$\mathrm{SiO}_{2}$

$\mathrm{Al}_{2} \mathrm{O}_{3}$

$\mathrm{CaO}$

$\mathrm{Na}_{2} \mathrm{O}$

0.204

0.0791

0.0241

0.237

0.166
$\mathrm{RuO}_{2}$

$\mathrm{Sb}_{2} \mathrm{O}_{3}$

$\mathrm{TeO}_{2}$

$\mathrm{Cs}_{2} \mathrm{O}$

Sro
52.30

11.44

14.0

6.04

3.59

1.06

1.4

4.99

1.93

1.06

0.43

0.0856

0.0791

0.0241

0.205

0.0813
14.4

3.15

3.85

1.66

0.99

0.29

0.39

1.37

0.53

0.29

0.12

0.024

0.022

0.007

0.056

0.022

Additives

$w t \%$

$\left.\begin{array}{lr}\mathrm{SiO}_{2} & 58.3 \\ \mathrm{Na}_{2} \mathrm{O} & 20.6 \\ \mathrm{~B}_{2} \mathrm{O}_{3} & 11.1 \\ \mathrm{CaO} & 5.6 \\ \mathrm{Li}_{2} \mathrm{O} & 4.4\end{array}\right\} \begin{aligned} & \text { Premelted Frit } \\ & (-200 \text { mesh })\end{aligned}$

Cornstarch" $\left(\mathrm{C}_{6} \mathrm{H}_{10} \mathrm{O}_{5}\right)_{n}$

3.6

7.8
$\mathrm{SiO}_{2}$
$\mathrm{Na}_{2} \mathrm{O}$
$\mathrm{B}_{2} \mathrm{O}_{3}$
$\mathrm{CaO}$
$\mathrm{Li}_{2} \mathrm{O}$

$\mathrm{Al}_{2} \mathrm{O}_{3}$
$\mathrm{SiO}_{2}$
150

53.1

28.6

14.4

11.4

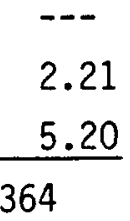

41.3

14.6

7.87

3.96

3.14

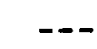

0.61

1.43

400

(a) Linde Ion SiV IE-95, $80 \% \mathrm{CaAl}_{2} \mathrm{Si}_{4} \mathrm{O}_{12} \cdot 6 \mathrm{H}_{2} \mathrm{O}, 20 \% \mathrm{Na}_{4} \mathrm{Ca}_{1} \cdot{ }_{5} \mathrm{Al}_{3} \mathrm{Si}_{8} \mathrm{O}_{24} \cdot 7 \mathrm{H}_{2} \mathrm{O}$.

(b) Alumino-silicate clay assumed to be $\mathrm{Al}_{2} \mathrm{O}_{3} \cdot 4 \mathrm{SiO}_{2} \cdot \mathrm{H}_{2} \mathrm{O}$. 
The second major occurrence of foaming during Periods 1 and 2 was that which resulted in termination of the feeding. This foaming was detected by observing the glass in vent holes which form in the "cold cap" to release decomposition gases. Low melt temperatures may have caused foaming to begin as the increased viscosity of the glass would restrict the release of decomposition gases. The low glass temperatures would indicate insufficient power input to the electrodes.

The foaming at this time was associated with an increase in floor temperatures. This can be seen in Figures 18 and 15. Figure 18 shows the glass temperature profiles taken three times during Periods 1 and 2. Profile $A$ was taken $1 / 2 \mathrm{~h}$ after the initiation of feeding for Period 1 . Profile $B$ was taken near the time when foaming was first observed, and Profile $C$ was taken immediately following the termination of feeding for Period 2. This sharp increase in the floor temperatures may have been the result of a compression in the conduction path between the electrodes due to the conversion of the upper-level glass to a higher resistance foam. This would have caused a greater concentration of power-generation near the floor.

Foaming during this time was not associated with a significant decrease in the temperature of the upper layer of glass. This type of behavior has, however, been apparent in demonstrations with calcine-fed melters (McElroy et a1. 1979). These decreases during foaming have been attributed to the sinking of the "cold cap" through the less dense foam. No such sinking occurred during the foaming in Feed Period 1. Instead, the crust floated on top until the foam dissolved. This effect could explain why a large decrease in the temperatures near the "cold cap" did not occur.

Interesting glass temperature effects were noted during the initial two feeding periods. Glass temperatures are normally 100 to $150^{\circ} \mathrm{C}$ above those of the electrodes. During this time, however, the measured glass temperature remained below the $1050^{\circ} \mathrm{C}$ temperature of the electrodes. This was probably due to the location of the thermowell near the feed-entry port. At this position a liquid pool would always exist on the "cold cap" during feeding, regardless of feed rate. The boiling liquid pool would act as a heat sink, lowering 


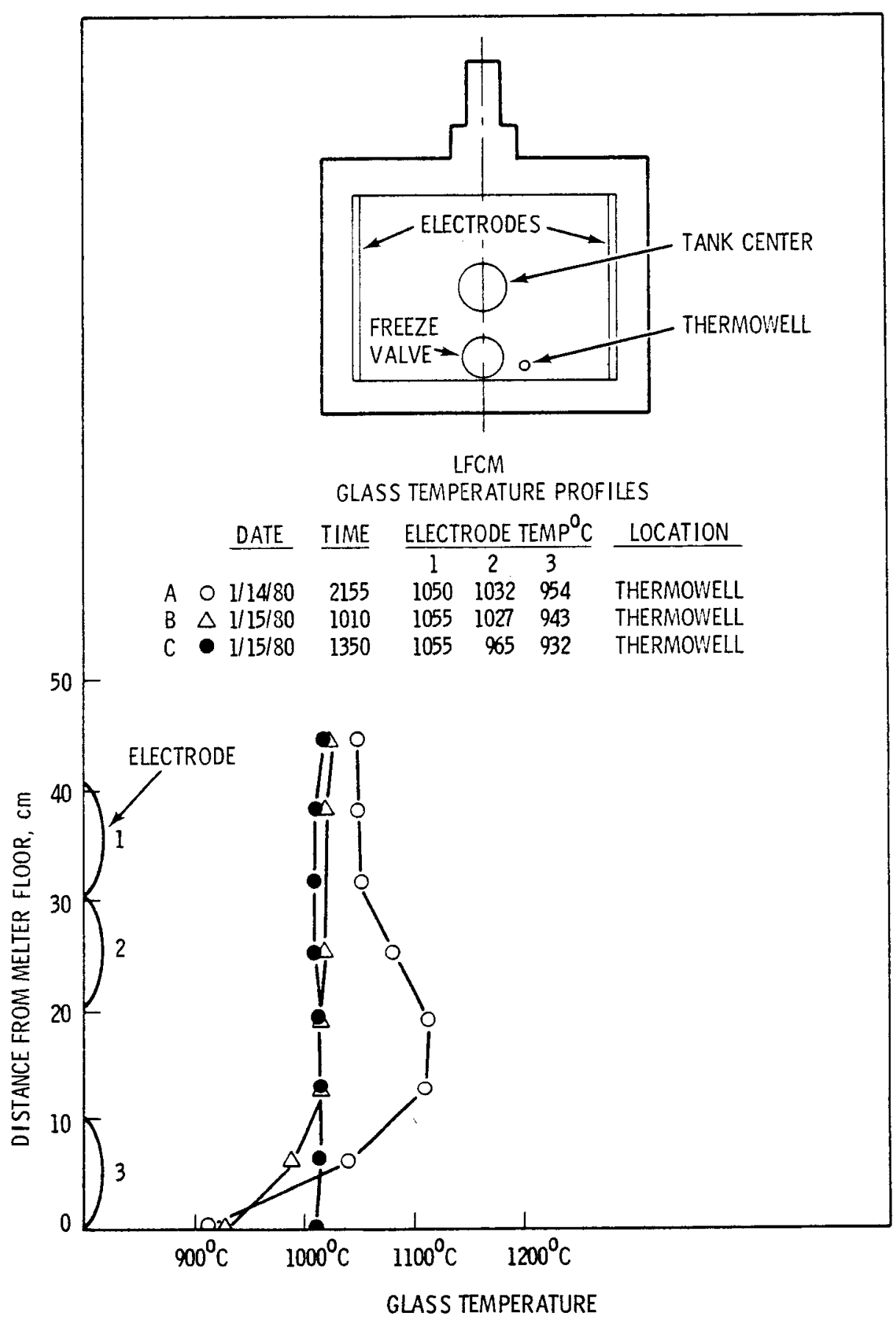

FIGURE 18. LFCM Glass-Temperature Profiles

the glass temperature. Also, temporary temperature drops were recorded as much as $12.7 \mathrm{~cm}$ below the "cold cap" when feeding was initiated or increased. 
Temperatures returned to normal as the waste dried and formed or increased the existing insulating crust between the liquid feed and glass.

\section{Feed Period 3}

Feed Period 3 was an attempt to operate the melter primarily on the power from the upper electrodes. This method of operation assumes greater heat generation will occur immediately below the "cold cap," causing enhanced heat transfer through the crust. By operating with a cool floor, the current flow in the warmer upper level of the glass should be greater because its resistance is lower. The disadvantage of this method of operation is that cooler floor temperatures promote crystalline precipitation and decrease convective mixing in the tank. Tank temperature profiles were not, however, as anticipated. Floor temperatures did not run noticeably lower during this period than the previous two, nor were temperatures near the surface significantly hotter. The temperatures in the mid-section, however, were slightly higher during Period 3, indicating a minor effect. Glass temperatures during Feed Period 3 are shown in Figure 15. Because the change in the temperature profile was insignificant, the power to the lower electrodes was increased after Period 3 and left at a constant current setting for the remainder of the run.

The foaming which terminated this feeding period resulted from a sudden increase in glass temperatures caused by a large increase in electrode power. These increases occurred at $30 \mathrm{~h}$ into the run and can be seen in Figures 15 and 16. Prior to this time, no foaming had been observed during this period. Less than 30 min after the increase, considerable foam was present. This release of oxygen from the melt, which causes foaming, is known as "reboil." "Reboil" and other mechanisms of foam generation are discussed in Appendix $D$. The increase was needed to stop a decline in electrode temperature caused by insufficient power for the feedrate. Earlier in the period, moderate increases had been effected but had not been sufficient.

\section{Feed Periods 4 and 5}

Feed Periods 4 and 5 were short due to plugging of the feed line and nozzle. Therefore, no data are reported. 


\section{Feed Period 6}

Period 6 totaled $14.5 \mathrm{~h}$, consisting of $3.2 \mathrm{~h}$ at an average feedrate of $49 \mathrm{~L} / \mathrm{h}, 7.1 \mathrm{~h}$ at an average feedrate of $80 \mathrm{~L} / \mathrm{h}$ and $4.2 \mathrm{~h}$ of feeding at an average feedrate of $105 \mathrm{~L} / \mathrm{h}$. Operation was stable through the first $10.3 \mathrm{~h}$ of feeding. During this period several interesting and important observations were made regarding direct liquid feeding of the simulated defense-waste glass.

Steady-state operation was achieved during approximately the last $2 \mathrm{~h}$ of feeding at $80 \mathrm{~L} / \mathrm{h}$. Steady-state operation was considered to be when the electrode, glass and plenum temperatures, as well as the power input, were as nearconstant as could be expected. Fluctuations in the feedrate, melter temperatures and power levels are inherent in the system, but these fluctuations were at a minimum during the steady-state operation as can be seen in Figures 15 , 16, and 17. Verification that steady-state conditions were present was made through an energy balance on the melter. Figure 19 is a summary of the energy balance made. The data for Balance 1 was taken during the last $2 \mathrm{~h}$ of feeding at $80 \mathrm{~L} / \mathrm{h}$, and Balance 2 was taken $\sim 3 \mathrm{~h}$ after the increase to $105 \mathrm{~L} / \mathrm{h}$ was made.

The energy losses in the offgas were a combination of the measured noncondensables and the calculated steam based on the feedrate. The energy lost by glass discharge or accumulation was also a calculated value based on the feedrate. The net heat input is the difference between the steady-state heat losses and the heat input.

Balance 1 confirms that the heat input was sufficient to operate the melter at steady state. Since the melter temperatures showed no net change during the $2 \mathrm{~h}$ the melter was considered to be at steady state, the output must have equaled the input and no feed accumulation in the melter occurred. However, Balance 2 showed insufficient power input during the $4-1 / 2 \mathrm{~h}$ at $105 \mathrm{~L} / \mathrm{h}$. During this period, the melter temperatures did not drop. Instead, they appeared to be increasing slightly or at least remaining constant, which indicates the feed slurry was accumulating. This conclusion reflects the overfeeding that occurred and resulted in an excessive buildup of liquid over the entire "cold cap." 
OFFGAS

BALANCE $1-60.6 \mathrm{~kW}$ ISTEAM PLUS DECOMPOSITION GASES AND IN-LEAKAGE AT $150^{\circ} \mathrm{C}$

LIQUID WASTE

BALANCE $2-68.9 \mathrm{~kW}$ ISTEAM PLUS DECOMPOSITION GASES AND IN-LEAKAGE AT $150^{\circ} \mathrm{C}$ )

BALANCE $1+0.4 \mathrm{~kW}\left(80 \mathrm{U} / \mathrm{h}\right.$ w/0. $36 \mathrm{~kg}$ OXIDES/L AT $\left.30^{\circ} \mathrm{C}\right)$

BALANCE $2+2 \mathrm{~kW}\left(105 \mathrm{Uh}\right.$ w/0. $36 \mathrm{~kg}$ OXIDES/L AT $\left.42^{\circ} \mathrm{C}\right)$

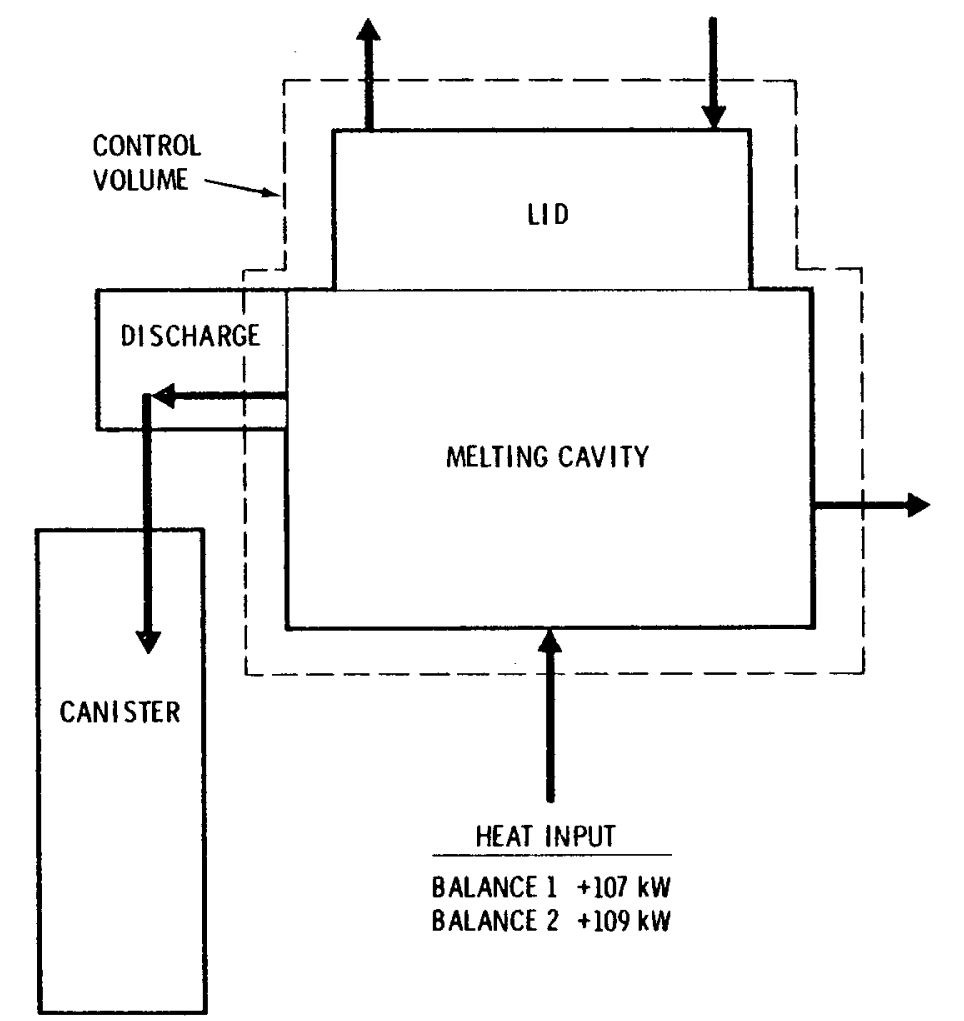

HEAT LOSSES

CHARGE AND GLASS

$\stackrel{\infty}{\infty}$

ACCUMULAIION

$\left(29 \mathrm{~kg} / \mathrm{h}\right.$ AT $\left.1010^{\circ} \mathrm{C}\right)$

BALANCE $2 \quad-8.7 \mathrm{~kW}$

$\left(38 \mathrm{~kg} / \mathrm{h}\right.$ AT $\left.1010^{\circ} \mathrm{C}\right)$

FIGURE 19. LFCM Heat Balance

\section{BALANCE $1=0.4 \mathrm{~kW}$}

BALANCE $2=-10.3 \mathrm{~kW}$
ELECTRODE COOLING:

FREEZE VALVE COOLING:

ALL OTHER:

TOTAL:
BALANC

$-16.3 \mathrm{~kW}$

$-7.8 \mathrm{~kW}$

$-15.7 \mathrm{~kW}$

$-39.8 \mathrm{~kW}$

BALANCE 2

$-15.6 \mathrm{~kW}$

$-7.8 \mathrm{~kW}$

$-20.3 \mathrm{~kW}$

$-43.7 \mathrm{~kW}$ 
Bridging of the "cold cap" occurred during the $105 \mathrm{~L} / \mathrm{h}$ period. Bridging, defined as the binding of the dried crust portion of the "cold cap" with the refractory walls of the melter, can result in 1) reduced melting rates due to the formation of a vapor gap between the melt and the crust, and 2) pressurization below the "cold cap" as a result of trapping decomposition gases. When not detected, bridging may result in a large accumulation of liquid on top of the crust which collapses the bridged crust and cause high offgas generation rates. During Period 3, pressurization below the "cold cap" resulted from the bridge that formed. This caused both a temporary high-glass pour rate and a large 20 -cm-dia vent hole to open in the crust. Fluctuations in the glass pouring rate were noticed as early as 10 min before the feedrate was increased to $105 \mathrm{~L} / \mathrm{h}$. These fluctuations, although minor, indicate that the bridge may have formed at $80 \mathrm{~L} / \mathrm{h}$ as well.

Samples of the "cold cap" taken during the run found the dried slurry zone to be a hard, dense, claylike material that would not easily crush contrasted to the loose powder-type of crust found in the lab studies with premelted frit (see Figure 8). From the standpoint of permeability and bridging potential, this form of "cold cap" is less desirable than the powder type. Bridging would be more likely since the dried slurry forms a strong crust that would likely bond to the walls. Also, the higher density of the crust would make it less permeable to decomposition gases. The bridging that occurred during this run was not predicted by either the lab studies or lab-scale ceramic-melter tests. The frit size used for the lab studies with premelted frit was $-20+80$ mesh, and the 1ab-scale ceramic-melter tests used approximately $-30+100$ mesh (see Table 3). The full-scale tests used a -200 mesh frit. This difference in frit size may be the reason for the observed difference in "cold cap" permeability.

Venting of the decomposition gases from below the crust occurred during the run by way of vents through the crust. These vents were present during all periods of operation except for the initial formation of the "cold cap" that occurs over the first 2 to $4 \mathrm{~h}$ of a feed period. Venting during the "cold cap" formation period occurred around the edges of the "cold cap." A normal vent during Feed Period 4 was $\sim 8 \mathrm{~cm}$ in dia with two to three vents present at any one time. 
The release of gases from the vents created a boiling cavity of molten glass that continually threw or spat molten glass from the cavity. Some of the molten glass was thrown from the cavity with enough force that a sphere of molten glass would travel in a parabolic projectile reaching as much as $0.6 \mathrm{~m}$ above the "cold cap" and leaving a thin thread of molten glass behind it. The threads hung from the walls and gas sampling tubes suspended above the center of the melt, creating the appearance of cobwebs. These threads of glass did not create operational problems other than obstructing visibility. The feed slurry occasionally poured into the vents and either partially or completely sealed off the hole.

Detectable pressure surges, caused by momentarily high offgas rates, were experienced during portions of the feeding period when flooding of the melter occurred. These surges resulted when a large $(220 \mathrm{~cm}$ dia) vent hole was present with both slurry from the flooded surface and the feed nozzle pouring into the vent hole. The surges were not high enough however, to cause a pressurization of the melter.

A steady-state temperature profile for this period is shown in Figure 20. For comparison, a profile during idling is presented. The thermowell is located near a wal1; therefore, the temperatures are lower than in the center of the tank. This difference can be seen in Figure 20 for the two profiles taken at nearly the same time (Profiles $B$ and $C$ ).

\section{Feed Period 7}

Feed Period 7 was a $3-h$ period at $75 \mathrm{~L} / \mathrm{h}$ to demonstrate recovery from overfeeding and bridging.

\section{Feed System Performance}

The liquid-feed system was a high maintenance portion of the process. During the early periods of the run both plugging of the feed lines and erratic flow were problems. The line plugging was caused by solids settling (primarily $\mathrm{MnO}_{2}$ ) in a low spot of the feed line between the air disengaging chamber and the feed nozzle (see Figure 14). Rerouting of the feed line to eliminate the low spot reduced the frequency of plugging. Several partial pluggages occurred 


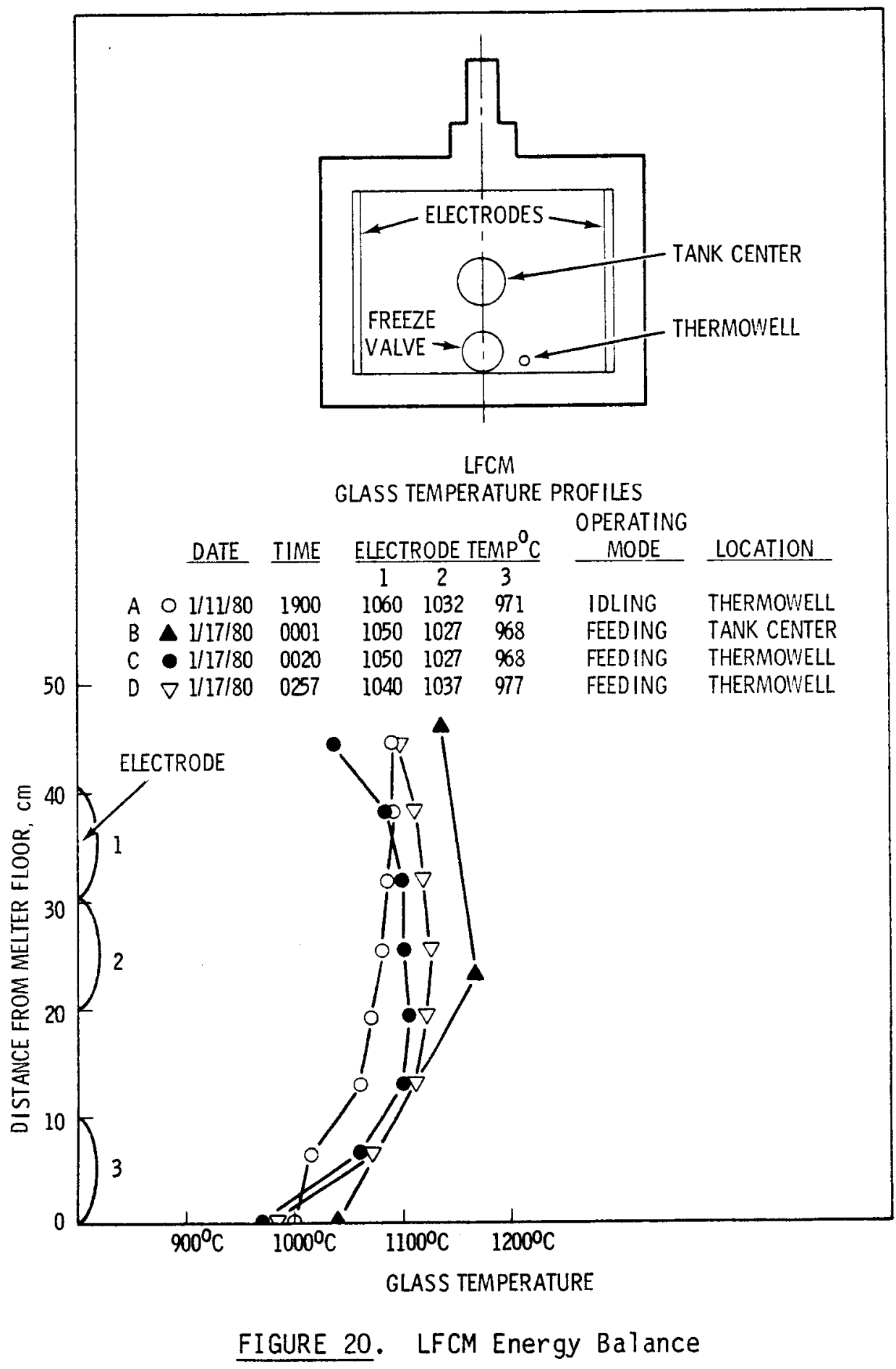

prior to the line rerouting. These pluggages are not noted in Figure 15 because they were detected early and a simple flush with water was sufficient to remove the blockage rather than a feed shutdown. The erratic feedrate was 
caused by a failure of the feed pump in maintaining a constant head of feed slurry in the airlift feed system. Replacement of the feed pump improved the system performance; however, refilling of the feed tank, when the liquid level reached $1 / 2$ full, was necessary to maintain the desired minimum recycle rate of $100 \mathrm{~L} / \mathrm{h}$.

The water-cooled feed nozzle plugged with dried solids once during the run. Redesign of the nozzle to increase the cooling should eliminate this problem in future tests. Feed-line and nozzle plugging were nonexistent during the final $19 \mathrm{~h}$ of the run. This success was attributed to the higher feedrates maintained during this period. At higher flowrates, solids settling is less likely, and an increase in the cooling effect on the nozzle by the feed slurry occurs. 


\section{PRODUCT CHARACTERIZATION}

Samples of the melter feed, batch cover and glass poured from the LFCM were taken periodically during the run. Feed samples were analyzed for solids settling rate, water content, density, and chemical composition. The batch cover and glass product were analyzed for chemical composition alone.

\section{LIQUID FEED}

Table 7 shows the target composition used during the LFCM run. Zeolite, which is present in this defense composition, supplied small amounts of $\mathrm{Al}_{2} \mathrm{O}_{3}$, $\mathrm{Na}_{2} \mathrm{O}$ and $\mathrm{SiO}_{2}$. Bentonite, a clay mineral added as a suspending agent, supplied additional $\mathrm{Al}_{2} \mathrm{O}_{3}$ and $\mathrm{SiO}_{2}$. The total $\mathrm{kg}$ of oxide/L of feed was 0.3629 . Also shown in the table are the weight percents of each oxide in the feed, if the feed were dried and entirely oxidized.

TABLE 7. Oxide Makeup of Liquid Feed

\begin{tabular}{|c|c|c|c|c|c|c|}
\hline \multirow[b]{2}{*}{ Compound } & \multirow{2}{*}{$\begin{array}{c}\text { Simulated } \\
\text { Defense } \\
\text { Waste } \\
\end{array}$} & \multicolumn{5}{|c|}{$\mathrm{kg} \mathrm{Oxide/L}$ of Feed } \\
\hline & & Zeolite(a) & Bentonite (a) & Glass Frit & Total & $\begin{array}{c}\text { Total, } \\
\text { wt\% }\end{array}$ \\
\hline & & $(0.0104)$ & $(0.0078)$ & & & \\
\hline $\mathrm{Al}_{2} \mathrm{O}_{3}$ & 0.0114 & 0.0012 & 0.0027 & & 0.0153 & 4.22 \\
\hline $\mathrm{B}_{2} \mathrm{O}_{3}$ & & & & 0.0286 & 0.0286 & 7.88 \\
\hline $\mathrm{CaO}$ & 0.0036 & & & 0.0144 & 0.0180 & 4.96 \\
\hline $\mathrm{Fe}_{2} \mathrm{O}_{3}$ & 0.0523 & & & & 0.0523 & 14.41 \\
\hline $\mathrm{Li}_{2} \mathrm{O}$ & & & & 0.0114 & 0.0114 & 3.14 \\
\hline $\mathrm{Na}_{2} \mathrm{O}$ & 0.0017 & 0.0007 & & 0.0531 & 0.0555 & 15.29 \\
\hline $\mathrm{MnO}_{2}$ & 0.0140 & & & & 0.0140 & 3.86 \\
\hline $\mathrm{NiO}$ & 0.0060 & & & & 0.0060 & 1.65 \\
\hline $\mathrm{SiO}_{2}$ & & 0.0072 & 0.0042 & 0.1504 & $\underline{0.1616}$ & 44.59 \\
\hline & & & & & 0.3629 & 100 \\
\hline
\end{tabular}

(a) A portion of these components is water. Thus, the sum of the oxides contributed by them is less than the amount of their addition. 
In Figures 21, 22 and 23, the oxide compositions of the feed samples are plotted as a function of time. The data are plotted as percentage of target value. The target value wt\% for each oxide is the value from Table 7 . For example, the design loading for $\mathrm{Al}_{2} \mathrm{C}_{3}$ is 4.22 wt\%.

The figures show that the majority of the components were present at near to the desired level, relative to one another. The major exception to this was $\mathrm{Li}_{2} \mathrm{O}$, which was on $7 y$ present at 80 to $85 \%$ of the design loading during most of the run. Also, $\mathrm{MnO}_{2}$ appears to have had very erratic behavior probably due to a sampling error. This error would have resulted from settling out of the dense $\mathrm{MnO}_{2}$ powder used to supply this material to the feed. The $\mathrm{MnO}_{2}$ level in the glass was found to be very close to its design value. This same behavior has been previously noted when comparing samples of spray-calciner liquid feed and the glass produced during a spray/calciner ceramic-melter run. Its solution will require a different means of sampling the feed, or method of $\mathrm{Mn}$ addition to the slurry.

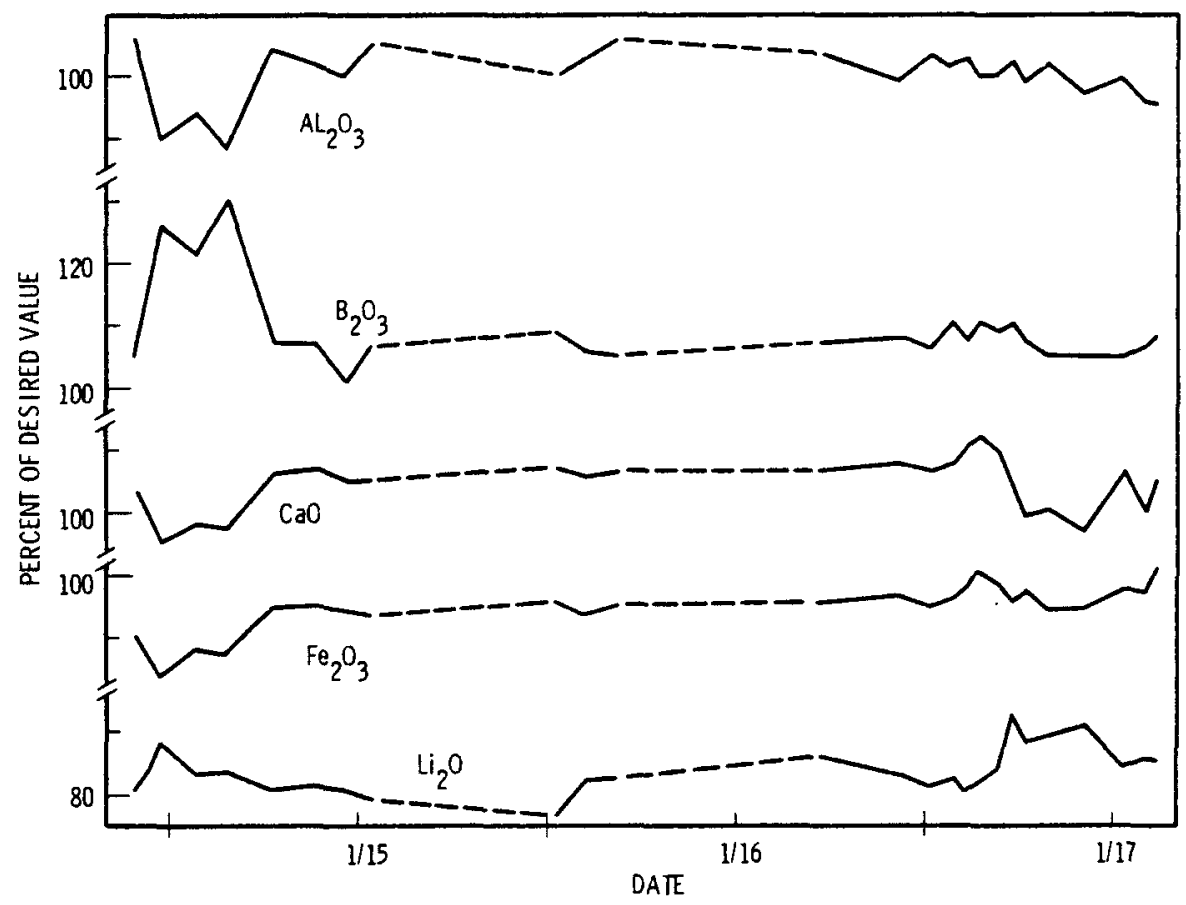

FIGURE 21. Oxide Composition of Liquid Feed, Percentage of Target Value 


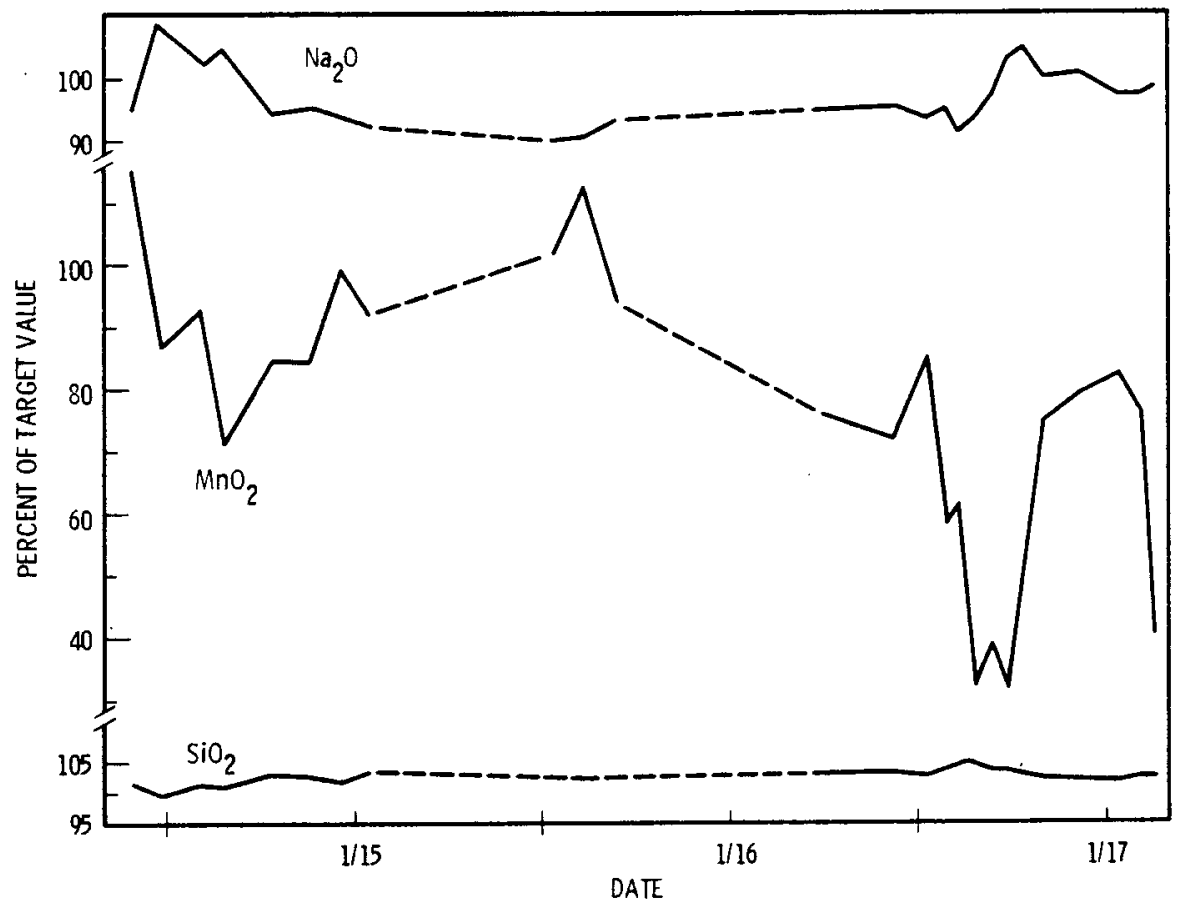

FIGURE 22. Oxide Composition of Liquid Feed, Percentage of Target Value

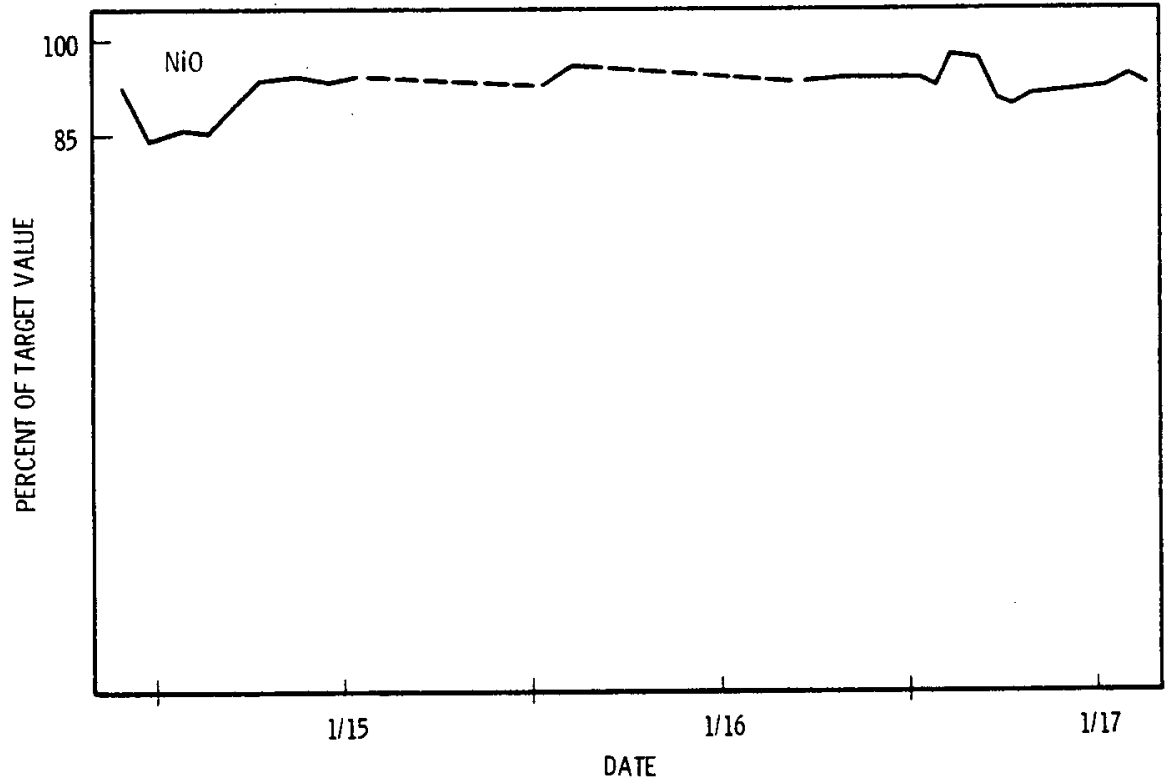

FIGURE 23. Oxide Composition of Liquid Feed, Percentage of Target value 
Figures 21,22 and 23 show that the feed composition remained fairly constant throughout the run, except at the very beginning. The oxide compositions of the feed samples are found in Appendix.C.

Figure 24 shows the total oxide content of the feed in $\mathrm{g} / \mathrm{L}$. Again, the values are plotted as percentage of target value. During the run, the oxide content remained stable at $\sim 85$ to $95 \%$ of the design leve1. Early on January 16, 1980, however, there was a sample taken with a very high solids content--almost $25 \%$ higher than called for. This high content may have been due to settling of the feed in the mixing or transfer tanks when feeding was stopped during the last half of January 15, 1980.

Figures 25,26 and 27 show the oxide loadings of the individual components. With the exception of $\mathrm{B}_{2} \mathrm{O}_{3}$, all of the oxides were present at lower than design values. The only component to be significantly low during the entire run was $L i_{2} \mathrm{O}$. The values of the individual oxide loadings are tabulated in Appendix C.

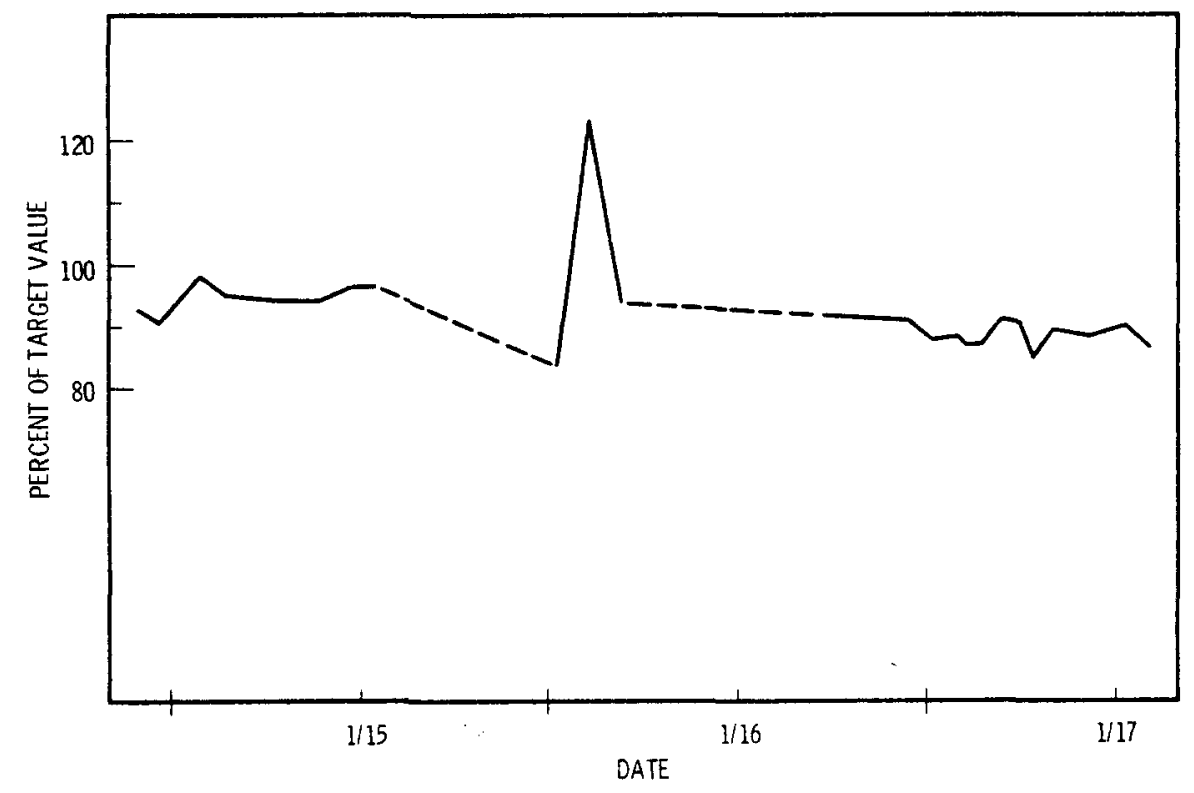

FIGURE 24. Total Oxide Loading of Liquid Feed, Percentage of Target, $g$ of $0 x i d e / L$ of Feed 


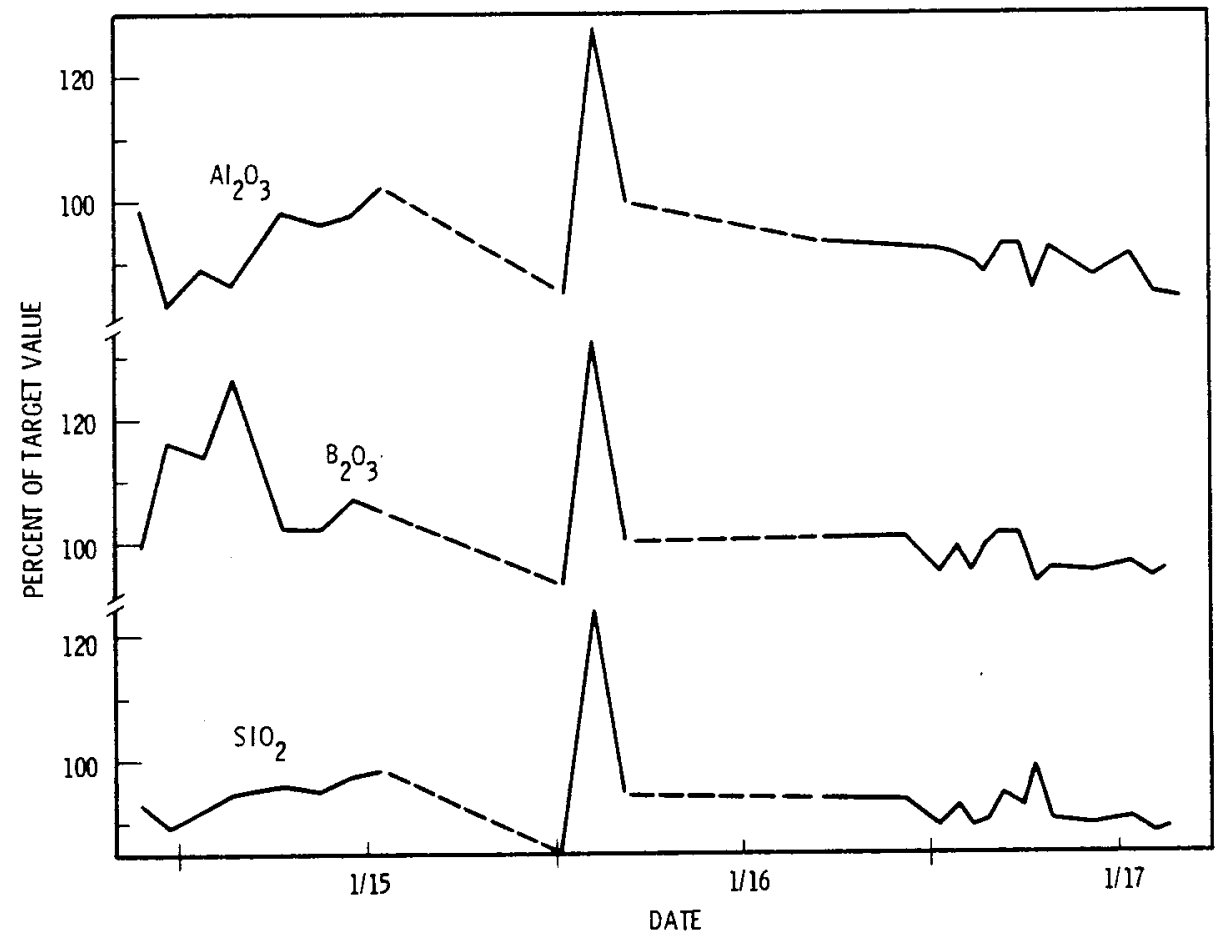

FIGURE 25. Composition of Liquid Feed, Percentage of Target, $g$ of Oxide/L of Feed

Figure 28 shows the density of the liquid feed as a function of time. During the majority of the run, the density remained stable at 21.5 to $1.29 \mathrm{~g} /$ $\mathrm{cm}^{3}$. Values were not measured during the first part of the run, but based on the solids content shown in Figure 24 , it is reasonable to assume that these would have been $\sim 1.25$ to $1.3 \mathrm{~g} / \mathrm{cm}^{3}$.

Settling of the feed was determined after feed samples were allowed to sit for $2 \mathrm{~d}$. The amount of settling was 220 to $25 \%$, most of which occurred during the first day.

\section{BATCH COVER}

Table 8 shows the chemical compositions of the batch cover samples taken during the run. As indicated, there was a significant amount of variation among these samples. Since these analyses do not correspond to those found 


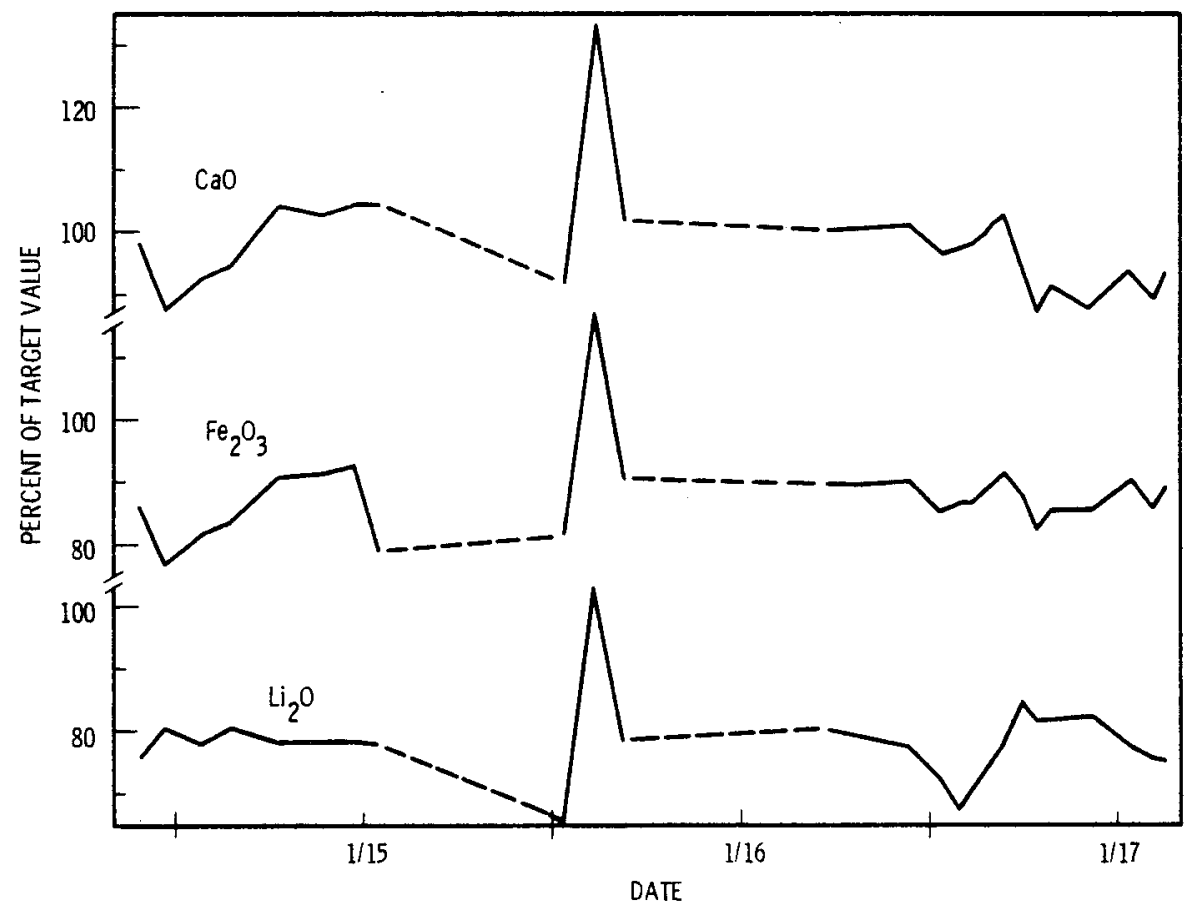

FIGURE 26. Composition of Liquid Feed, Percentage of Target, $g$ of Oxide/L of Feed

for the feed or resulting glass, it appears that chemical segregation probably occurred in the batch cover.

Table 9 shows the compositions of glass samples taken from the melt-batch cover interface. These samples are essentially identical in composition to the glass obtained during pouring of the canister. Thus, although some segregation of components occurs in the batch cover, once the material melts this segregation disappears and a we1l-mixed glass results. This glass is very close to the target composition.

\section{GLASS POUR SAMPLES}

Figure 29 shows the oxide composition of the glass samples obtained during the pouring of canisters. The data are plotted as percentage of target value. The majority of the components are present at very close to the desired level; the major exceptions, $\mathrm{Fe}_{2} \mathrm{O}_{3}, \mathrm{NiO}, \mathrm{Li}_{2} \mathrm{O}$ and $\mathrm{MnO}_{2}$, were also low in the 


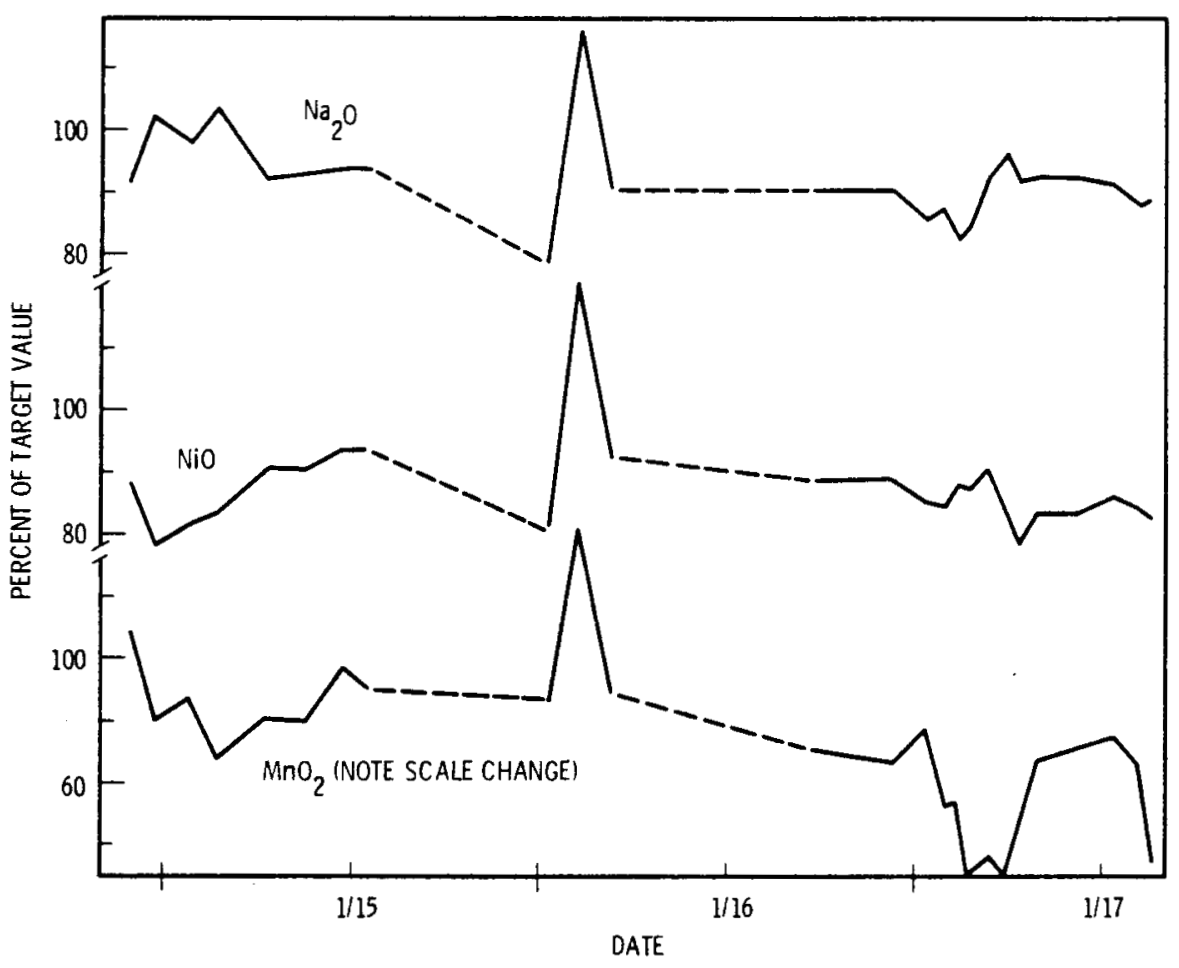

FIGURE 27. Composition of Liquid Feed, Percentage of Target, $g$ of Oxide/L of Feed

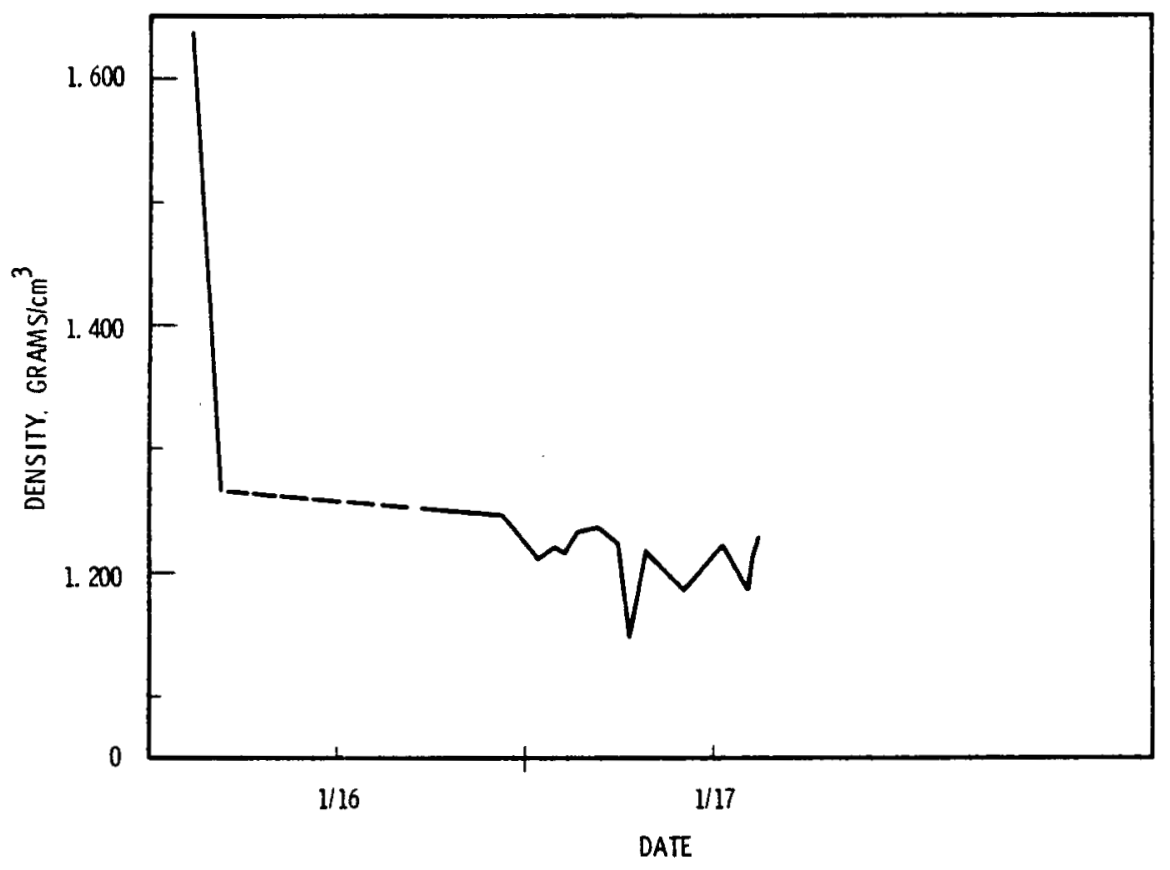

FIGURE 28. Density of Liquid Feed as a Function of Time 
TABLE 8. Compositions of Samples from Batch Cover

\begin{tabular}{|c|c|c|c|c|c|}
\hline \multirow[b]{2}{*}{ Compound } & \multicolumn{5}{|c|}{ Batch Cover Samples, wt\% } \\
\hline & $\begin{array}{c}\text { Target } \\
\text { Composition } \\
\end{array}$ & $\begin{array}{c}1-17 \mathrm{~d} \\
1140 \mathrm{~h} \\
\mathrm{~A} \\
\end{array}$ & $\begin{array}{c}1-170 \\
1140 \mathrm{~h} \\
\mathrm{~B} \\
\end{array}$ & $\begin{array}{c}1-170 \\
1530 \mathrm{~h} \\
\mathrm{~A} \\
\end{array}$ & 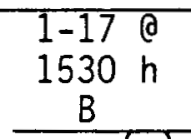 \\
\hline$\overline{\mathrm{Al}_{2} \mathrm{O}_{3}}$ & 4.22 & $2.26^{(2)}$ & $4.29^{(a)}$ & $3.62^{(a)}$ & $4.13^{(a)}$ \\
\hline $\mathrm{B}_{2} \mathrm{O}_{3}$ & 7.88 & 3.58 & 5.04 & 10.29 & 8.68 \\
\hline $\mathrm{CaO}$ & 4.96 & 7.37 & 6.52 & 4.62 & 5.38 \\
\hline $\mathrm{Fe}_{2} \mathrm{O}_{3}$ & 14.41 & 24.13 & 19.27 & 12.88 & 15.03 \\
\hline $\mathrm{Li}_{2} \mathrm{O}$ & 3.14 & 1.77 & 2.05 & 2.43 & 2.71 \\
\hline $\mathrm{Na}_{2} \mathrm{O}$ & 15.29 & 8.76 & 10.86 & 17.25 & 14.89 \\
\hline $\mathrm{MnO}_{2}$ & 3.86 & 0.89 & 2.75 & 2.41 & 2.88 \\
\hline $\mathrm{NiO}^{6}$ & 1.65 & 1.13 & 1.71 & 1.41 & 1.68 \\
\hline $\mathrm{SiO}_{2}$ & 44.59 & 50.12 & 4.75 & 44.57 & 45.08 \\
\hline
\end{tabular}

(a) All weight-percent values of batch cover samples were normalized to $100 \%$.

TABLE 9. Compositions of Glasses Taken from Melt-Batch Cover Interface

\begin{tabular}{|c|c|c|c|c|}
\hline \multirow[b]{2}{*}{ Compound } & \multicolumn{4}{|c|}{$\begin{array}{l}\text { Glass Samples from Melt-Batch } \\
\text { Cover Interface, wt\% }\end{array}$} \\
\hline & $\begin{array}{l}\text { Target } \\
\text { Composition }\end{array}$ & $\begin{array}{c}1-170 \\
1140 \mathrm{~h} \\
\mathrm{~A} \\
\end{array}$ & $\begin{array}{c}1-170 \\
1140 \mathrm{~h} \\
\mathrm{~B} \\
\end{array}$ & $\begin{array}{rr}1-17 & 0 \\
1530 & h \\
\mathrm{C}\end{array}$ \\
\hline $\mathrm{A}_{2} \mathrm{O}_{3}$ & 4.22 & 4.31 & 4.51 & 4.12 \\
\hline $\mathrm{B}_{2} \mathrm{O}_{3}$ & 7.88 & 8.38 & 8.48 & 8.48 \\
\hline CaO & 4.96 & 5.05 & 4.95 & 5.02 \\
\hline $\mathrm{Fe}_{2} \mathrm{O}_{3}$ & 14.41 & 13.3 & 13.0 & 13.4 \\
\hline $\mathrm{Li}_{2} \mathrm{O}$ & 3.14 & 2.80 & 3.13 & 2.90 \\
\hline $\mathrm{Na}_{2} \mathrm{O}$ & 15.29 & 14.5 & 16.4 & 15.1 \\
\hline $\mathrm{MnO}_{2}$ & 3.86 & 3.51 & 3.43 & 3.36 \\
\hline $\mathrm{NiO}$ & 1.65 & 1.33 & 1.33 & 1.37 \\
\hline $\mathrm{SiO}_{2}$ & 44.59 & 44.5 & 45.9 & 44.6 \\
\hline
\end{tabular}

feed. It is hard to say whether the low $\mathrm{MnO}_{2}$ values were due to the feed or not since it was impossible to determine the actual value of $\mathrm{MnO}_{2}$ in the feed. 


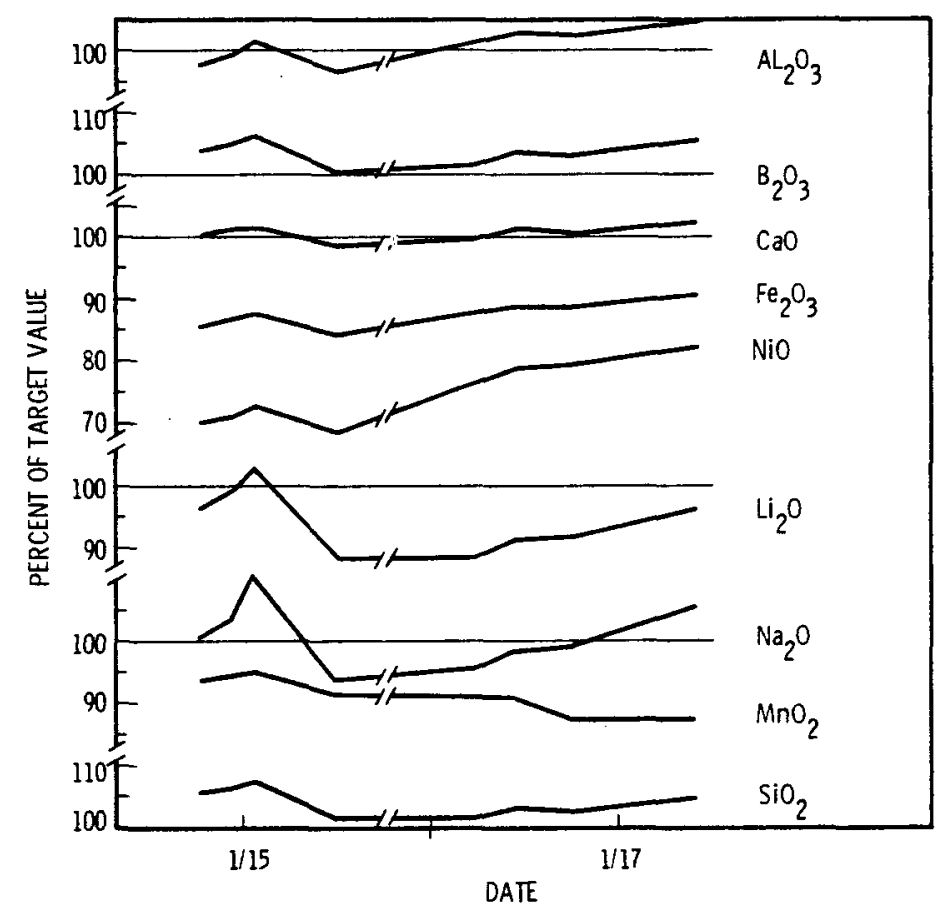

FIGURE 29. Oxide Composition of Pour Glass Samples, Percentage of Target Value

The low $\mathrm{Fe}_{2} \mathrm{O}_{3}$ and $\mathrm{NiO}$ values may have been due to spinel formation; however, due to the small quantity of glass processed during the run relative to the size of the melter, it is estimated that only a $50 \%$ change-out of the initial glass in the melter had occurred. Therefore, the final concentration of the glass components is not necessarily the same as the steady-state concentration. If one assumes the $\mathrm{Fe}_{2} \mathrm{O}_{3}$ and $\mathrm{NiO}$ levels in the final glass samples are the same as the steady-state levels (a worst-case assumption), then the spinel formation is $1 / 2$ as high in this liquid-fed test than in calcine-fed tests at PNL.

This effect can be seen by comparing the amounts of iron and nickel lost during this run with that seen during tests using a feed composed of frit and calcine. In this liquid-fed run, the glass contained about $10 \%$ less $\mathrm{Fe}_{2} \mathrm{O}_{3}$ and $20 \%$ less NiO than the feed samples. During a recent test of glass-making with frit and calcine, 20 to $30 \%$ of the iron oxide and 20 to $40 \%$ of the nickel oxide were lost. Cornstarch was present during both runs, and no evidence of 
metals reduction and precipitation to account for the lost $\mathrm{Fe}_{2} \mathrm{O}_{3}$ and $\mathrm{NiO}$ were found in the calcine-fed run when samples from the bottom of the melter were examined. It is reasonable to assume that no metal formation occurred during this LFCM test either. 


\section{EFFLUENT ANALYSIS}

\section{EFFLUENT SAMPLING SYSTEM}

The effluent sampling system designed for characterizing LFCM offgases and entrained particles consists of four main components (see Figure 30):

- volatile plating sampler

- gas scrubbing system

- gas sample ports and an inline sample cylinder

- classical-scattering aerosol spectrometer (CSAS).

Plating behavior of volatilized glass components was studied using a plating sampler which consisted of two $25-\mathrm{mm}$-dia by $147-\mathrm{mm}-1$ ong quartz glass tubes supported end-to-end above the melt. The tube surfaces were roughened by sandblasting. Scale and spatterings on the tubes were analyzed by an inductioncoupled plasma (ICP) spectrometer. The plenum temperature profile was monitored and recorded during the experiment.

Waste-glass components, as well as radionuclide substitutes leaving the melter due to volatilization and entrainment, were recovered using a gas scrubbing system. The system consisted of:

- a 15.4-mm (1/4-in.) heat-traced stainless steel sample tube attached to the top of a water-cooled condenser

- a trap to collect condensate

- a 500-mL scrubber containing $0.2 \mathrm{M}$ nitric acid $\left(\mathrm{HNO}_{3}\right)$

- a second $500-\mathrm{mL}$ scrubber containing $1.0 \mathrm{M}$ sodium hydroxide $(\mathrm{NaOH})$

- a liquid trap

- a rotameter

- a vacuum pump

- a flow totalizer.

The condensate and scrub solutions were analyzed by ICP for all elements except cesium, which was by atomic adsorption, and $\mathrm{Cl}^{-}, \mathrm{NO}_{3}{ }^{-}$and $\mathrm{SO}_{4}{ }^{2-}$, which were by ion chromatographic and specific-ion electrode techniques. 


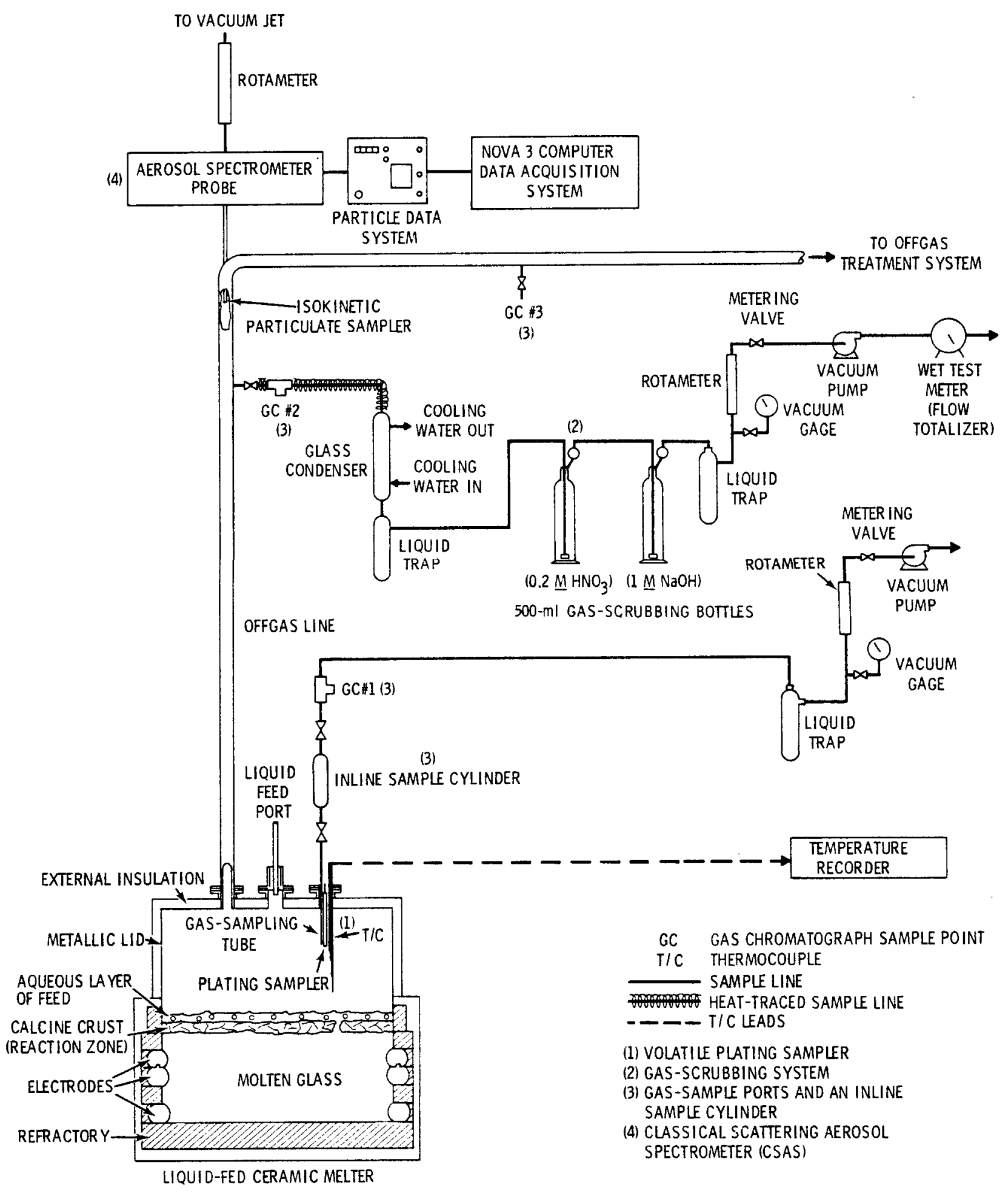

FIGURE 30. LFCM Effluent Sampling System 
Noncondensable effluents were analyzed using a gas chromatograph (GC) and a mass spectrometer for carbon dioxide, carbon monoxide, oxygen and nitrogen. Gas chromatograph samples were taken with a 20-cc syringe injected through Teflon discs at sample points \#1, \#2, and \#3 (see Figure 30). Mass spectrometry samples were taken with a 75-cc stainless steel in-line sample cylinder placed in the gas sample line below GC sample point \#1.

The mass loadings and size distributions of entrained particulate were studied using a CSAS. These parameters are important for design of a process offgas system.

The CSAS system is composed of:

- an isokinetic sample port

- a Particle Measuring Systems Inc. (PMSI) Model CSASP-100 He-Ne laser probe

- a PMSI model PDS-200 particle data system

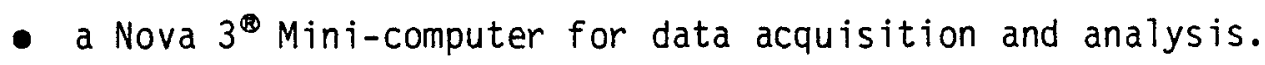

The isokinetic sample port is a $2.54-\mathrm{cm}\left(1-\mathrm{in}_{\text {. }}\right)$-dia stainless steel tube centered in the offgas line (refer to Figure 30 ).

The PMSI model CSASP-100 He-Ne laser probe is designed to detect up to 30 size channels simultaneously in a $0.3-$ to $20-\mu \mathrm{m}$ particle-size range using a high-resolution, element-refraction imaging system in its collecting optics.

The probe is calibrated using monodispersed latex spheres; therefore, the particles counted during sampling are assumed to be spheres. The size of the particle is determined by the pulse height (intensity) of the scattered light. This differs from that of other size distribution measuring devices, such as cascade impactors, that separate particles based on their aerodynamic size.

The PMSI particle data system model PDS-200 is a data acquisition and recording system designed for use with the standard PMS particle spectrometer

Data General Corporation, Kirkland, Washington. 
probe. The PDS-200 allows for on-line monitoring of particle characterization and ease of CSASP-100 probe calibration and has capabilities to output data to the Data General Nova 3 computer for data acquisition and graphic interpretation.

The Data General Nova 3 computer is used to process data from the PSD-200 through data conversion and data analys is programs. During spectrometer operation, data automatically are transfered to the Nova 3 for disc storage. The data-acquisition system outputs sets of data which are stored on the disc. Data analysis programs are used to normalize and average the data sets. Then, the gas sample flow rates are input and the program calculates particle count, masses and mass percentages as a function of particle size. The program then plots all the particle count and mass distribution data.

A gas sample was drawn through the CSAS at a mean rate of $9.84 \mathrm{~m} / \mathrm{sec}$ by a steam jet with the flow controlled by a metering valve on a rotameter. The sample flow was started 30 min prior to collecting data, thus allowing the system temperature to reach an equilibrium. The CSAS was operated for 60 to $120 \mathrm{sec}$ per data set.

\section{MELTER AND SAMPLING SYSTEM OPERATING SUMMARY}

The liquid-feed target composition (elemental basis) and actual composition is shown in Table 10 . The feed was a mixture of $72 \mathrm{wt} \% \mathrm{glass}$ former and 28 wt\% generic defense-waste sludge as the anticipated waste oxides. Nonradioactive trace isotopes of $\mathrm{Sr}, \mathrm{Ru}, \mathrm{Sb}, \mathrm{Te}$, and $\mathrm{Cs}$ were added to the feed. All trace elements except $\mathrm{Sr}$ are considered to be semivolatile. Two weight-percent bentonite was added as a suspending agent along with 1- to 2-wt\% cornstarch.

Table 11 gives a summary of run conditions during time periods which the gas scrubbing system was operated. The scrub system was operated at three different times during steady state and once during startup and once during foaming. During steady state, the percent of melt surface flooded ranged from 80 to $100 \%$, and the plenum temperature ranged from 94 to $273^{\circ} \mathrm{C}$. The plenum 
TABLE 10. Liquid-Feed Composition

\begin{tabular}{|c|c|c|c|}
\hline Component (a) & $\begin{array}{c}\text { Target } \\
\text { Composition, } \\
\text { g/L }\end{array}$ & $\begin{array}{c}\text { Average } \\
\text { Composition, } \\
\mathrm{g} / \mathrm{L}\end{array}$ & Deviation (b) \\
\hline $\begin{array}{l}\mathrm{Li} \\
\mathrm{B} \\
\mathrm{Na} \\
\mathrm{Al} \\
\mathrm{Si} \\
\mathrm{Ca} \\
\mathrm{Mn} \\
\mathrm{Fe} \\
\mathrm{Ni}\end{array}$ & $\begin{array}{r}5.30 \\
8.88 \\
40.95 \\
8.25 \\
74.76 \\
13.61 \\
8.85 \\
36.58 \\
4.75\end{array}$ & $\begin{array}{r}4.14 \\
9.10 \\
38.01 \\
8.94 \\
70.92 \\
12.64 \\
6.31 \\
32.15 \\
3.40\end{array}$ & $\begin{array}{l}0.36 \\
0.89 \\
3.04 \\
0.85 \\
5.48 \\
1.19 \\
2.29 \\
2.68 \\
0.32\end{array}$ \\
\hline $\mathrm{Cl}^{-}$ & 0 & 4.58 & 0.37 \\
\hline $\begin{array}{l}\mathrm{Sr} \\
\mathrm{Ru} \\
\mathrm{Sb} \\
\mathrm{Te} \\
\mathrm{CS}\end{array}$ & $\begin{array}{l}0.0687 \\
0.0650 \\
0.0661 \\
0.0193 \\
0.1934\end{array}$ & $\begin{array}{l}0.110 \\
0.816 \\
0.234 \\
0.206 \\
0.169\end{array}$ & $\begin{array}{l}0.012 \\
0.079 \\
0.023 \\
0.022 \\
0.021\end{array}$ \\
\hline
\end{tabular}

(a) The compositions are given in elemental form but are present as hydroxides, oxides carbonates, nitrates and sulfates.

(b) Standard deviation for 25 samples taken during liquid feeding.

temperature was lowest during periods of complete flooding. Melter in-leakage was quite high due to leaks in the lid and was typically greater than $80 \%$ of the total flow.

\section{RESULTS}

Noncondensable Offgas

The average noncondensable offgas analysis from the three gas chromatograph sample ports and the in-line sample cylinder is shown in Table 12. Average concentrations of all gas samples taken during steady-state liquid feeding, foaming, and idling are shown. No concentration trends were observed between the different sample locations or between the gas chromatograph and mass spectrometer sample analysis. The $\mathrm{CO}_{2}$ concentration is the highest during foaming, and the $\mathrm{O}_{2}$ concentration is higher than the air reference during 
TABLE 11. Run Conditions During Scrubbing System Sampling

\begin{tabular}{|c|c|c|c|c|c|}
\hline $\begin{array}{c}\text { Melter } \\
\text { Operational } \\
\text { Mode } \\
\end{array}$ & $\begin{array}{c}\text { Average LFCM } \\
\text { Feedrate, } \\
L / h \\
\end{array}$ & $\begin{array}{c}\text { LFCM Melt } \\
\text { Surf ace } \\
\text { Flooded, (a) (\%) }\end{array}$ & $\begin{array}{l}\text { Average } \\
\text { Plenum Tem- } \\
\text { perature, }{ }^{\circ} \mathrm{C}\end{array}$ & $\begin{array}{l}\text { Melter Air } \\
\text { In-Leak age, (b) } \\
\text { sec/m (scfm) }\end{array}$ & $\begin{array}{c}\text { Total Offgas } \\
\text { Flow, (B) } \\
\mathrm{L} / \mathrm{m}(\mathrm{scfm}) \\
\end{array}$ \\
\hline Startup & 60 & 0 & $100-920$ & $9,450 \quad(334)$ & $10,530(372)$ \\
\hline Steady State & $\begin{array}{l}67 \\
60 \\
60\end{array}$ & $\begin{array}{r}90 \\
100 \\
80\end{array}$ & $\begin{array}{r}273 \\
94 \\
149\end{array}$ & $\begin{array}{r}12,030(434) \\
4,300(152) \\
6,100(215)\end{array}$ & $\begin{array}{r}13,230(467) \\
5,370(190) \\
7,170(253)\end{array}$ \\
\hline Foaming & -- & 0 & $100-970$ & -- & -- \\
\hline Average & 62 & & $7,470 \quad(281)$ & $9,075(320)$ & \\
\hline
\end{tabular}

(a) Melt surface flooded describes the percentage of the melt surface covered by liquid.

(b) Calculated flow based on condensate volume and liquid-feed rate. Assumes $862 \mathrm{~g} \mathrm{H} 2 \mathrm{O} / \mathrm{L}$ feed and scrub-sample dew-point of $25^{\circ} \mathrm{C}$.

foaming. This indicates that $\mathrm{CO}_{2}$ and $\mathrm{O}_{2}$ are being evolved from the melt during foaming. During idling both the $\mathrm{O}_{2}$ and $\mathrm{CO}_{2}$ levels are lower than the reference air, indicating the melt is absorbing or somehow reacting with these components. This supports a current theory of foaming by pye (1979), which is discussed in Appendix D.

Volatilized and Entrained Constituents

Volatilized and entrained glass components, including radionuclide substitutes, were recovered using the gas scrubbing system previously described and shown in Figure 30.

Scrub solutions were analyzed for all elements; then, the results were corrected by subtracting out the initial elemental concentrations present in the fresh scrub solutions. Elemental quantities present in the trap and both scrubbing bottles were totaled and converted to an offgas concentration basis ( $\mathrm{\mu g} / \mathrm{std} \mathrm{L}$ offgas). Offgas concentrations of major glass components and radionuclide substitutes as well as steady-state decontamination factors are presented in Table 13. Concentrations of ion species are presented in Table 14. The most prominent glass component present is sodium with lesser quantities of silicon and boron. Sodium metal has the lowest boiling point $\left(883^{\circ} \mathrm{C}\right)$ followed by lithium $\left(1317^{\circ} \mathrm{C}\right)$ and both elements have relatively low boiling chlorides and hydroxides $\left(<1400^{\circ} \mathrm{C}\right)$; thus, higher volatilities for these elements would be 
TABLE 12. Average Noncondensable Offgas Composition During Liquid Feeding (a)

\begin{tabular}{|c|c|c|c|c|c|}
\hline & & Gaseo & ompon & vol\% & \\
\hline & $\mathrm{CO}_{2-}$ & $\underline{0}_{2-}$ & $\mathrm{N}_{2}$ & $\mathrm{CO}$ & Ar \\
\hline $\begin{array}{l}\text { Steady-State Liquid Feeding } \\
\text { (no foam) }\end{array}$ & 0.104 & 23.6 & 75.4 & 0.001 & 0.96 \\
\hline Foaming & 0.222 & 23.1 & 75.7 & $\cdots$ & 0.96 \\
\hline Idling & 0.021 & 19.5 & 79.5 & --- & 0.96 \\
\hline Air, vol\% & 0.061 & 21.0 & 78.1 & -- & 0.96 \\
\hline Average Standard Deviation(b) & 0.07 & 2.1 & 2.1 & 0.01 & --- \\
\hline
\end{tabular}

(a) Dry basis
(b) Up to seven samples taken during each condition

expected. Elemental $B$ is not volatile (melting point $2300^{\circ} \mathrm{C}$ ); however, boric oxide, the form used in the feed makeup, and boric acid are more volatile. In a water vapor atmosphere, $\mathrm{B}_{2} \mathrm{O}_{3}$ is known to be unstable and loses weight when heated above $250^{\circ} \mathrm{C}$ (Williams 1978). The higher the airflow and the more vigorous the boiling (typical of the LFCM during operation), the greater is the $\mathrm{B}_{2} \mathrm{O}_{3}$ vaporization. The highest offgas concentration of most elements was during steady-state operation with lesser amounts evident during foaming and startup.

Of the trace elements, $C s$ has the lowest average decontamination factor (DF) (Table 13). The cesium volatility ranged from 4.2 to 110 and appeared to be dependent upon run parameters; however, a mechanism has not been identified. Cesium, being in the same alkali metal family as $\mathrm{Na}$ and Li, has the lowest boiling point $\left(690^{\circ} \mathrm{C}\right)$, and in turn was observed to have the lowest $\mathrm{DF}$. Sodium and $L i$ have higher boiling points and show higher DFs, respectively. The cesium DF ranged from 4.2 to 110 , which corresponds to weight losses of 0.91 to $24 \%$ (a) The average loss to the offgas system of the semivolatile trace

(a) This volatility is substantially higher than previously observed by J. L. Buelt, Research Scientist, PNL. He observed Cs volatility losses of 0.4 to 1.4 wt\% when feeding simulated power-reactor waste. 
TABLE 13. Elemental Offgas Concentrations and Steady-State Decontamination Factors $(a)$

Element

Major Glass Elements

Li

B

$\mathrm{Na}$

A1

$\mathrm{Si}$

$\mathrm{Ca}$

$\mathrm{Mn}$

$\mathrm{Fe}$

$\mathrm{Ni}$

TOTAL
0.12

2.80

5.97

0.17

0.41

0.72

0.06

0.58

0.12

10.95
Offgas Concentration, (b) $\mu \mathrm{g} / \mathrm{std}$ L Offgas Melter Operation Mode
Steady State (c) Foaming
Average Decont amination Factor (DF) During Steady State

Radionuclide Substitutes

$\begin{array}{lcccr}\text { Sr } & 0.138 & 0.010 & 0.004 & 7,400 \\ \text { Ru } & 0.023 & 0.160 & 0.049 & 810 \\ \text { Sb } & 0.002 & 0.031 & 0.039 & 1,700 \\ \text { Te } & <0.06 & 0.110 & <0.06 & 3,000 \\ \text { Cs } & \underline{0.257} & \underline{2.734} & \underline{0.420} & 44 \\ \text { TOTAL } & 0.257 & 3.045 & 0.512 & -.-\end{array}$

(a) The decontamination factor (DF) is the ratio of mass entering the melter with the feed to the mass leaving with the offgas.

(b) Combined quantity from trap, $0.2 \mathrm{M} \mathrm{HNO}_{3}$ scrubber, and $1.0 \mathrm{M} \mathrm{NaOH}$ scrubber except for $\mathrm{Na}$ and Si which are combined quantities from trap and $0.2 \mathrm{M}$ $\mathrm{HNO}_{3}$ scrubber only. Caustic scrub solution invalidates $\mathrm{Na}$ analysis and tends to leach $\mathrm{Si}$ from the glass scrubber. Elemental concentrations of reference samples are subtracted from the scrub analysis.

(c) Average of three sample periods.

elements during steady state is as follows: Ru, $0.16 \%$; Sb, $0.11 \%$; Te, $0.44 \%$; and Cs, 13\%. These losses do not correspond to the average DFs reported in 
TABLE 14. Chloride, Nitrate and Sulfate Offgas Concentrations

\begin{tabular}{|c|c|c|c|c|c|c|c|}
\hline \multirow[b]{3}{*}{ Operational Mode } & \multirow{3}{*}{$\begin{array}{l}\text { Number of } \\
\text { Samples }\end{array}$} & \multicolumn{6}{|c|}{ Ion Concentrations, (a) $\mu q / s t d L$ Offaas } \\
\hline & & \multicolumn{2}{|c|}{$\mathrm{Cl}^{-}$} & \multicolumn{2}{|c|}{$\mathrm{NO}_{2}^{-}$} & \multicolumn{2}{|c|}{ SO $2-$} \\
\hline & & Trap & Total & Trap & Total & Trap & Total \\
\hline Startup & 1 & 6.55 & 14.9 & 18.6 & (b) & 0.81 & (b) \\
\hline Steady State & 2 & 94.8 & 282 & 2.79 & (b) & 10.2 & (b) \\
\hline Foaming & 1 & 58.76 & (c) & 50.28 & (b) & 0.76 & (b) \\
\hline
\end{tabular}

(a) Total concentrations are sum of concentration trap and $0.2 \mathrm{M} \mathrm{HNO}_{3}$ scrubber.

(b) $\mathrm{NO}_{3}^{-}$analys is of $\mathrm{HNO}_{3}$ scrub not performed. High $\mathrm{NO}_{3}^{-}$concentration in the scrub interfered with $\mathrm{SO}_{4}{ }^{2-}$ analysis.

(c) $\mathrm{HNO}_{3}$ scrub not analyzed.

Table 13. They are based on average elemental loss during the three steadystate sample periods as opposed to the averaged DF of those sample periods. There were periods during the run when all species exhibited higher DFs. No mechanism for this behavior has been identified. The ruthenium DF was high, ranging from 530 to 1000 and averaging 810 . Ruthenium tetraoxide is a liquid at $25.5^{\circ} \mathrm{C}$ and has been the cause of high Ru volatility under oxidizing conditions. The defense waste is neutralized, thus minimizing the Ru oxidation potential.

The most prominent ion species collected by the scrub system are $\mathrm{Cl}^{-}$followed by $\mathrm{NO}_{3}{ }^{-}$, then $\mathrm{SO}_{4}{ }^{2-}$. The $\mathrm{Na}$ to $\mathrm{Cl}$ mole ratio during steady-state operation was 1.0 to 3.1, which indicates that most of the $\mathrm{Cl}^{-}$exists in some form besides $\mathrm{NaCl}$. In a LFCM production unit, the melter lid and offgas components must be fabricated from materials resistant to $\mathrm{Cl}^{-}$, and $\mathrm{NO}_{3}{ }^{-}-$and $\mathrm{SO}_{4}{ }^{2-}$-induced corrosion.

\section{Plating and Particulate Constituents}

Plating behavior of volatilized glass components was studied using a plating sampler previously described and shown in Figure 30 . The sampler was suspended from the melter lid for $15.75 \mathrm{~h}$ during steady-state melter operation.

Due to a period of melter foaming and continual spattering of the liquid feed, the plating samplers collected feed and glass along with volatilized 
species. Since one is unable to differentiate between the two effects, the data are not reported.

Table 15 presents the analysis results of a particulate sample taken from the offgas line. The particulate sample composition ratios do not resemble those of the feed because each oxide has a different volatility. All the

TABLE 15. Particulate Sample Compositions

\begin{tabular}{|c|c|c|c|}
\hline \multirow[b]{2}{*}{ Oxide Forms } & \multirow{2}{*}{$\begin{array}{c}\text { Feed Component } \\
\text { Composition, (a) } \\
\text { wt\% }\end{array}$} & \multicolumn{2}{|c|}{$\begin{array}{l}\text { Offgas Line } \\
\text { Particulate Sample(b) }\end{array}$} \\
\hline & & $\begin{array}{l}\text { Composition, } \\
\text { wt\% } \\
\end{array}$ & $\begin{array}{c}\text { Fraction of Glass } \\
\text { Composition }\end{array}$ \\
\hline \multicolumn{4}{|c|}{ Major Glass Components } \\
\hline $\mathrm{Li}_{2} \mathrm{O}$ & 2.66 & 1.45 & 0.67 \\
\hline $\mathrm{B}_{2} \mathrm{O}_{3}$ & 8.75 & 2.41 & 0.28 \\
\hline $\mathrm{Na}_{2} \mathrm{O}$ & 15.30 & - & $-\cdots$ \\
\hline $\mathrm{Al}_{2} \mathrm{O}_{3}$ & 4.26 & 0.71 & 0.17 \\
\hline $\mathrm{SiO}_{2}$ & 45.32 & 12.30 & 0.27 \\
\hline $\mathrm{CaO}$ & 5.28 & 1.83 & 0.35 \\
\hline $\mathrm{MnO}_{2}$ & 2.98 & 0.10 & 0.03 \\
\hline $\mathrm{Fe}_{2} \mathrm{O}_{3}$ & 13.73 & 4.94 & 0.36 \\
\hline $\mathrm{NiO}$ & 1.57 & 0.39 & 0.25 \\
\hline
\end{tabular}

Radionuclide Substitutes

Sro

$\mathrm{RuO}_{2}$

$\mathrm{Sb}_{2} \mathrm{O}_{3}$

$\mathrm{TeO}_{2}$

$\mathrm{Cs}_{2} \mathrm{O}$

TOTAL

\begin{tabular}{c}
0.0098 \\
0.0809 \\
0.0215 \\
$<0.025$ \\
0.135 \\
\hline
\end{tabular}

$100 \%$
0.0158

1.6

2.5

0.90

$<0.025$

50

(a) Based on actual elemental analysis and assumes oxide form as shown (normalized to $100 \%$ )

(b) Sodium analysis not valid since sample was fused in Na for ICP analysis. Solid sample taken from sample system 1 ine contained $27.6 \% \mathrm{Na}$ and $44 \% \mathrm{Cl}$. 
major glass components are less abundant, especially the oxides of aluminum and manganese. Approximately 75 wt\% of the sample was not accounted for and is believed to be $\mathrm{Na}$ and $\mathrm{Cl}$. Neither a $\mathrm{Na}$ nor $\mathrm{Cl}$ analysis was performed on the sample due to the small quantity collected. A second particulate sample taken from the plenum sample system line was analyzed and found to contain $27.6 \% \mathrm{Na}$ and $44 \% \mathrm{Cl}$ (a $1: 1.03$ mole ratio). Of the trace elements, Ru and Cs are the most abundant, having 2.5 and 50 times, respectively, the concentration of the feed oxides. The Sb and $S r$ remained relatively constant in all the samples, and no Te was detected in any of the samples.

Particle Loading and Size Distribution

Entrained particles in the offgas line were analyzed by using a CSAS. A sample stream was drawn isokinetically from the offgas line and passed through the CSAS probe. The CSAS measures, analyzes and reports particle-size distribution data in four overlapping size ranges which cover the total particle diameter range of 0.32 to $20 \mu \mathrm{m}$. The mini-computer removes overlap during data reduction and integration.

Figures 31 and 32 are graphs of the average data from four particle sample periods during idling, normalized to $900-\mathrm{sec}$ sample intervals. Figure 31 shows the particle count versus particle size. The graph shows that $95 \%$ of the particles are less than $1.5 \mathrm{\mu m}$ in dia and the count peaks at a size range smaller than the instrument limitation of $0.32 \mu \mathrm{m}$. There are, however, particles up to the size of $5.5 \mathrm{\mu m}$. Figure 32 shows the mass distribution for the same runs as in Figure 31. The maximum mass loading occurs between 0.6 to $0.7 \mu \mathrm{m}$.

Figures 33 and 34 are graphs made from the averaged data of two sample periods during liquid feeding, normalized to $60 \mathrm{sec}$. More than $99.9 \%$ of the particle count and mass, respectively, are below the 0.7-um range. As was the case in idling, the liquid-feeding data also shows that the particle count peaks below the $0.32-\mu \mathrm{m}$-size range. The maximum mass-loading for liquid feeding occurs at $0.4 \mu \mathrm{m}$, and particles were detected up to $3.2 \mu \mathrm{m}$.

The particulate loadings in the offgas line are based on the CSAS particle counts. The particles are assumed to be spherical and to have a particle 


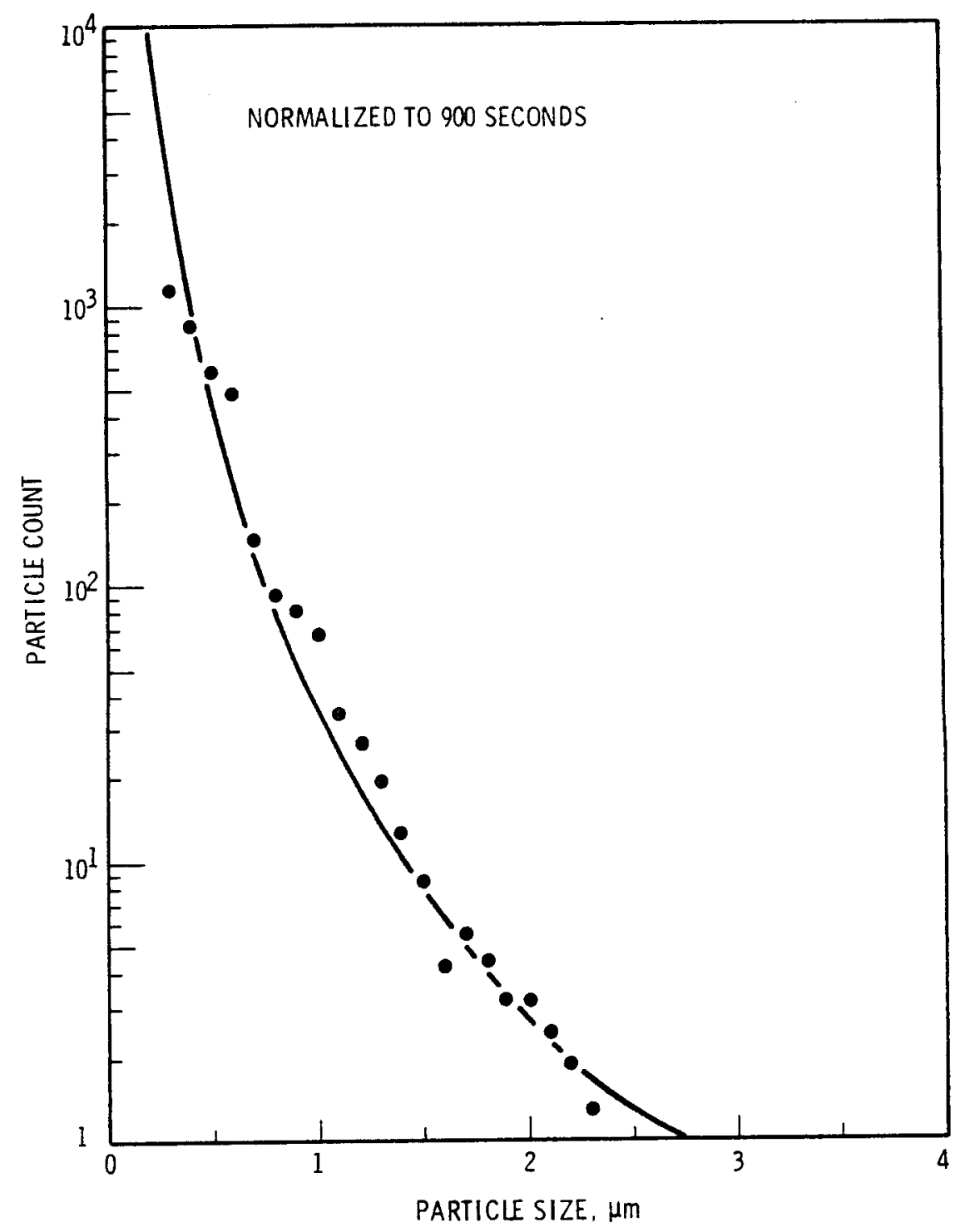

FIGURE 31. Particle Count Versus Particle Size Liquid-Fed Ceramic Melter: Idling

density of $4.0 \mathrm{~g} / \mathrm{cm}^{3}$. Particle concentrations ranged between 12.8 and $14.1 \mathrm{\mu g} / \mathrm{L}$ gas. Using the average steady-state feed rate of $62 \mathrm{~L} / \mathrm{h}$ and the average offgas flow of $8590 \mathrm{~L} / \mathrm{min}$, the average steady-state particulate DF was calculated to be 1700 . The aerosol spectrometer DF of 1700 is believed to be large because 1) a fraction of the particles were smaller than the detection 


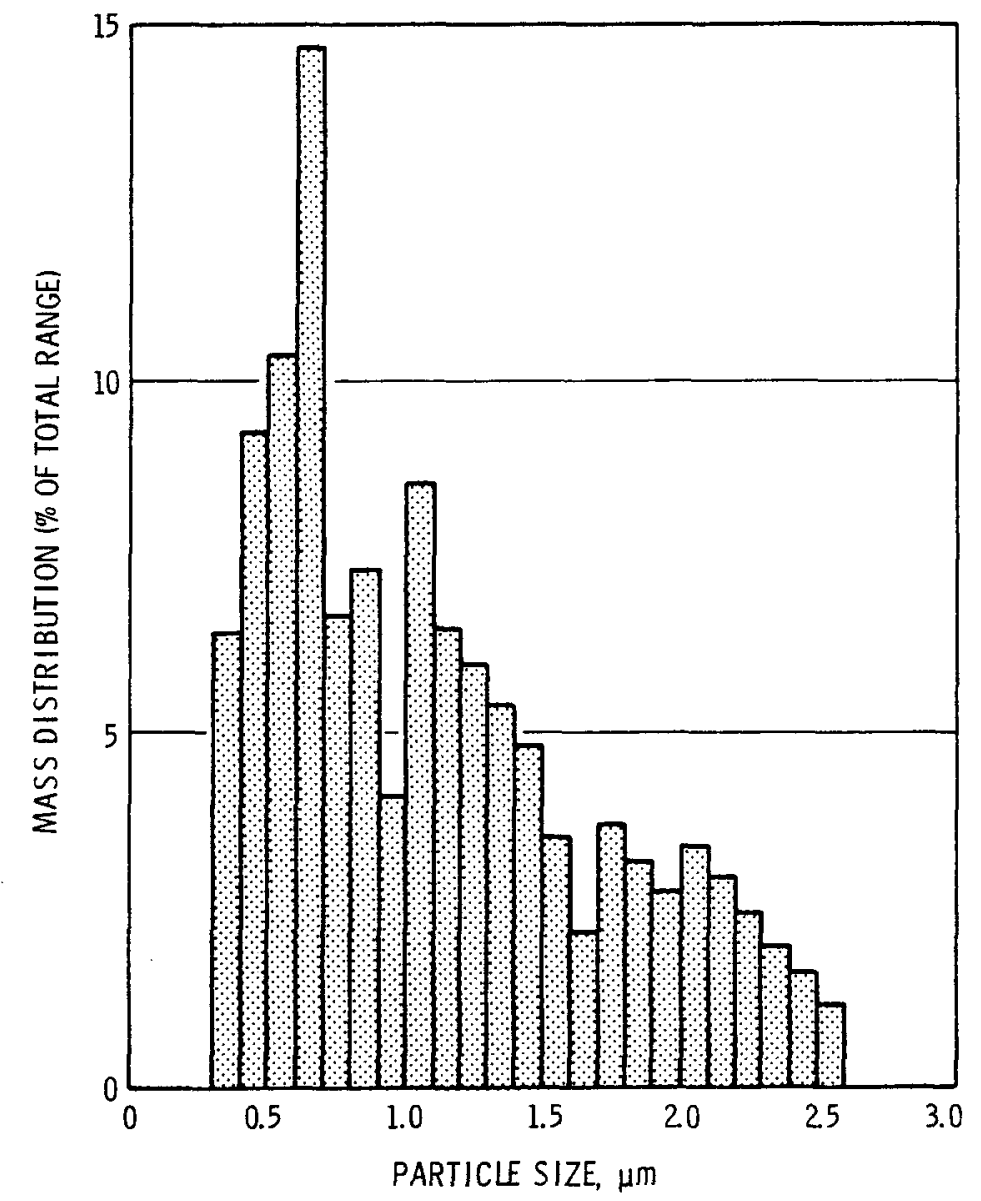

FIGURE 32. Mass Versus Particle Size Liquid-Fed Ceramic Melter: Idling

limit of the instrument, and 2) the sampling line to the spectrometer probe was not isothermal. It was insulated but not heat-traced, and cooling may have caused water condensation in the sample tube. It was thought that water condensation caused deposition of the particles in the sample tube, thus reducing the particle loading seen by the spectrometer probe.

Table 16 shows a steady-state liquid feeding DF comparison from the scrubbing system, the aerosol spectrometer, and previous DFs from HEPA-filter weight differences. (a) Elements with oxide boiling points much higher than the glass

(a) Data supplied by J. L. Buelt, Research Scientist, PNL. 


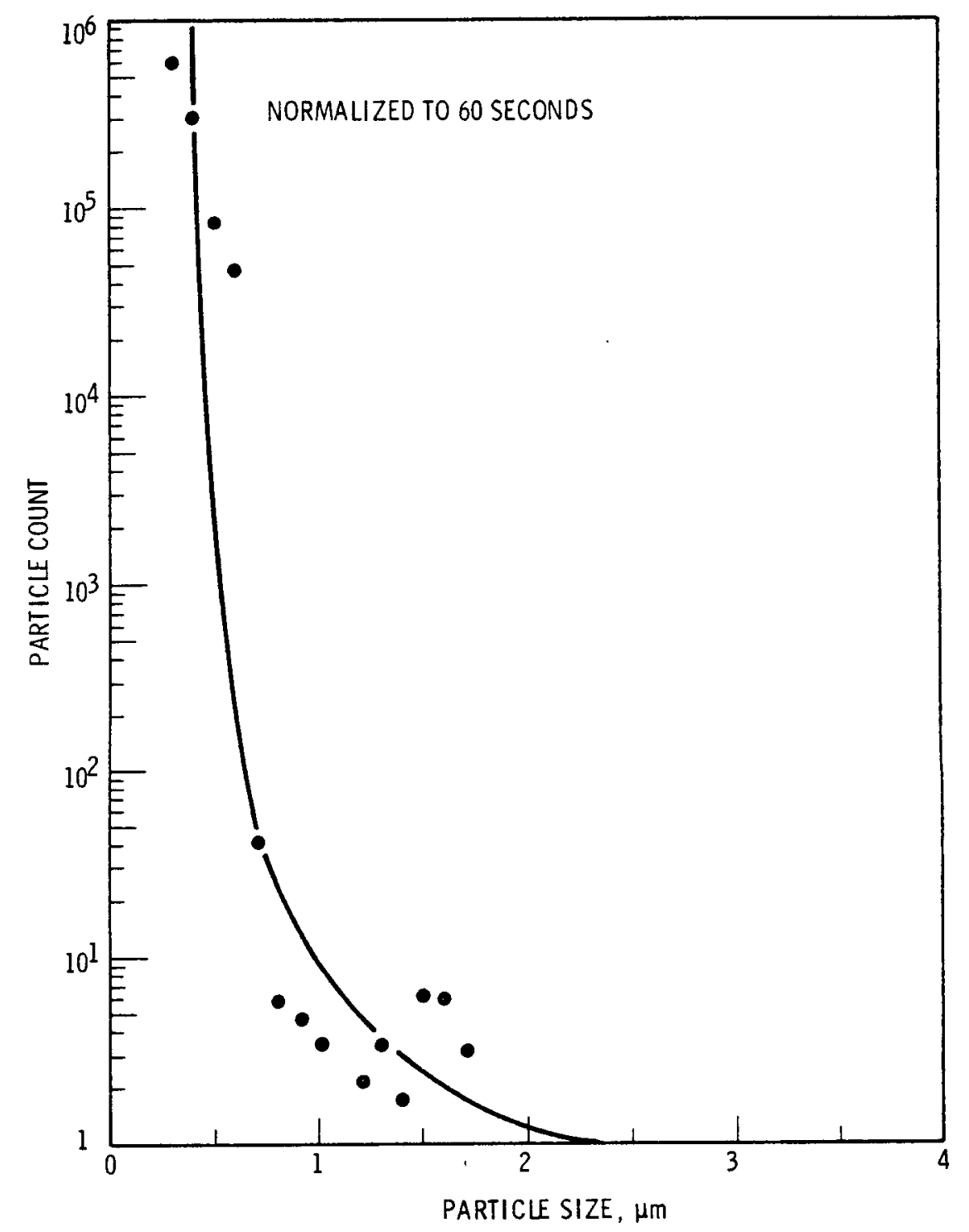

FIGURE 33. Particle Count Versus Particle Size Liquid-Fed Ceramic Melter: During Feeding

temperature were chosen to calculate a nonvolatile DF from the data in Table 13. The DF based on those numbers should indicate the actual particle carry-over into the offgas. The average nonvolatile DF obtained from the sampling system was 4500 , or 0.02 wt\% of the solids are leaving the melter by entrainment. The ratio of all of the elements into the melter and all of 


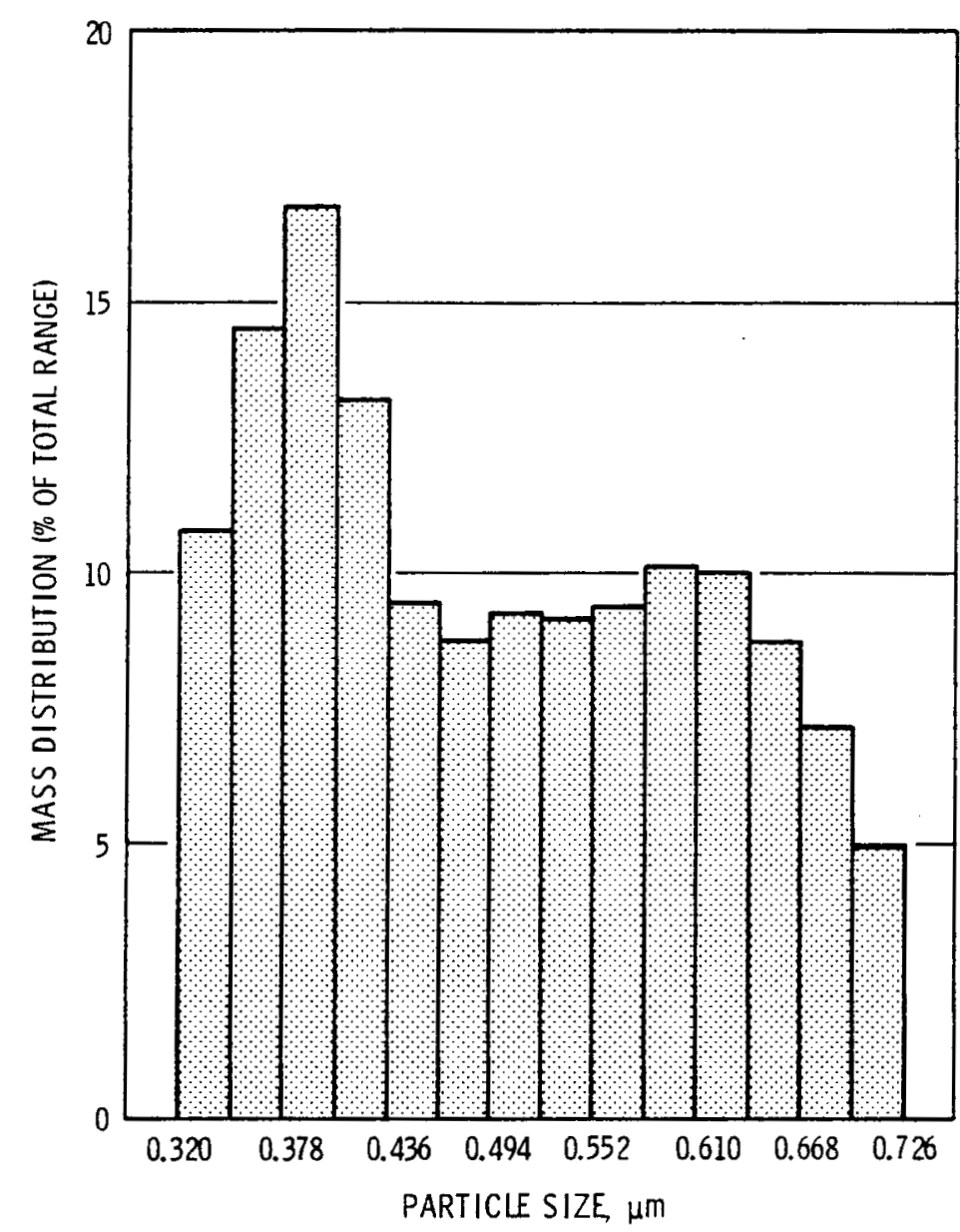

FIGURE 34. Mass Versus Particle Size Liquid-Fed Ceramic Melter: During Feeding

the elements collected in sampling system gives a much lower DF, 520. This number compares we 11 with the nominal DF of greater than 200 from previous data but is less than $1 / 3$ of the DF based on the aerosol spectrometer data, 1700. Elements with low DFs, such as Li, B, Na, Ru, Sb, Te and Cs, are leaving the melter by volatilization in addition to particulate entrainment. Previous LFCM CS loss-numbers for power-reactor (acid) wastes have indicated CS losses between 0.4 and 1.4 wt\% (Buelt, PNL), while this work shows higher losses of 0.91 to $24 \mathrm{wt} \%$.

Table 17 shows particulate loading in the offgas for idling, steady-state liquid feeding and previous work from spray calcination (Hanson 1980). The 
TABLE 16. Decontamination Factor(a) Comparison During Steady-State Liquid Feeding

\begin{tabular}{|c|c|c|c|}
\hline & $\begin{array}{l}\text { From Scrub } \\
\text { Analysis(a) }\end{array}$ & From CSAS & $\begin{array}{l}\text { From Previous } \\
\text { Data(b) }\end{array}$ \\
\hline Nonvolatiles $(c)$ & 4,500 & --- & --- \\
\hline Cs & 44 & --- & 71 to 250 \\
\hline Overall & 520 & $1,700^{(d)}$ & $>200$ \\
\hline
\end{tabular}

(a) DFs were calculated for each scrub sample period, then averaged.

(b) Data supplied by J. L. Buelt, Research Scientist, PNL (acid-waste feeding of LFCM).

(c) Al, $\mathrm{Si}, \mathrm{Ca}, \mathrm{Fe}, \mathrm{Ni}$ and $\mathrm{Sr}$ are considered nonvolatile.

(d) May be lower if volatiles are not condensed.

TABLE 17. Particulate Loadings and Diameter Range in the Offgas During Idling and Liquid Feeding

\begin{tabular}{|c|c|c|c|}
\hline & Idling (a) & Liquid Feeding (a) & $\begin{array}{c}\text { Spray } \\
\text { Calcination (b) } \\
\end{array}$ \\
\hline $\begin{array}{l}\text { Average Particulate Loading, } \\
\mu \mathrm{g} / \mathrm{std} \mathrm{L}\end{array}$ & 0.04 & 13.5 & 0.08 \\
\hline $\begin{array}{l}\text { Maximum Particulate Loading, } \\
\mu \mathrm{g} / \mathrm{std} \mathrm{L}\end{array}$ & 0.143 & --- & --- \\
\hline $\begin{array}{l}\text { Particulate Diameter Range, } \\
\mu \mathrm{m}\end{array}$ & 0.5 to 5.6 & $<0.3$ to 3.2 & 0.5 to 5 \\
\hline
\end{tabular}

(a) Based on aerosol spectrometer data.

(b) Hanson 1980.

particle-diameter ranges are similar for all three cases. The average particulate loadings for idling and spray calcination are roughly the same, while the particulate loading for liquid feeding without any filtration is only 100 times that of spray calcination with sintered metal filters. Offgas cleanup equipment operation was the same for liquid feeding as it was for spray calcination with no adverse affects in spite of the higher particulate loadings. 
The overa17 DF of 520 indicates that a total of $0.2 \mathrm{wt} \%$ of the solids are leaving the melter by volatilization and entrainment. As stated previously, the loss by entrainment alone is $0.02 \mathrm{wt} \%$ based on the nonvolatile average DF. The percentage of losses by volatilization based on these numbers is $90 \%$. If one chooses a single nonvolatile element instead of the six-element average (see Table 16) such as $\mathrm{Fe}$ or $\mathrm{Sr}$, the losses by entrainment are $0.05 \mathrm{wt} \%$, and the percentage of losses by volatilization is $70 \%$. Thus, one can conclude that between 70 and $90 \%$ of the melter losses were by volatilization with 10 to $30 \%$ by entrainment. 
0 $\theta$

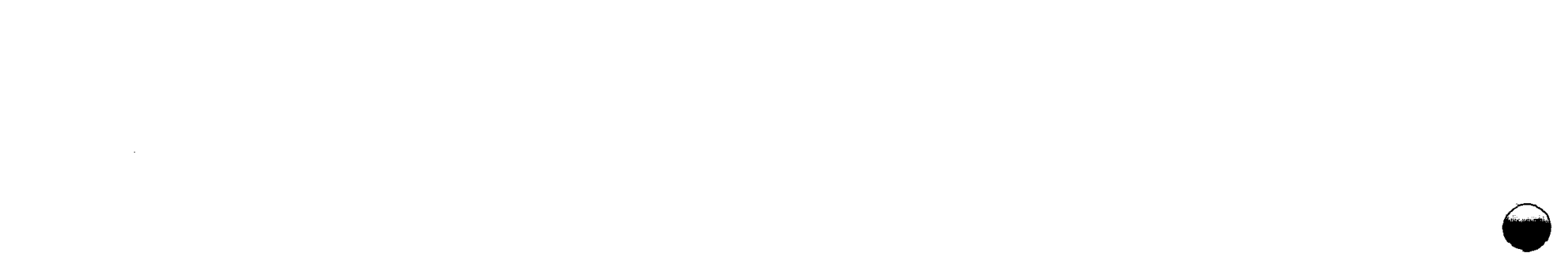




\section{REFERENCES}

Buelt, J. L., and C. C. Chapman. 1978. Liquid-Fed Ceramic Melter: A General Description Report. PNL-2735, Pacific Northwest Laboratory, Richland, WA 99352.

Bue1t, J. L., C. C. Chapman. 1979. "Slurry Feeding of Nuclear Waste to an Electric Glass Melter." Presented at the 50th Annual American Nuclear Society Meeting in Atlanta, Georgia. PNL-SA-7571, Pac if ic Northwest Laboratory, Richland, WA 99352.

Chapman, C. C. 1976. Experience with a Joule-Heated Ceramic Melter While Converting Simulated High-Level Waste to Glass. BNWL-2071, Pacific Northwest Laboratory, Richland, WA 99352.

Chapman, C. C. and J. L. Buelt. 1977. "Vitrification of High-Level Waste in a Joule-Heated Ceramic Melter." Presented at the 70th Annual AIChE Meeting in New York. PNL-SA-6375, Pacific Northwest Laboratory, Richland, WA 99352.

Hanson, M. S. 1980. Spray Calcination/In-Can Melting: Effluent Characterization and Treatment. PNL-3109, Pacific Northwest Laboratory, Richland, WA 99352.

McElroy, J. L. et al. 1979. Quarterly Progress Report - Research and Development Activities - High-Level Waste Immobilization Program: April Through June 1979. PNL-3050-2, Pacific Northwest Laboratory, Rich1and, WA 99352.

Postma, A. K., C. C. Chapman, and J. L. Buelt. 1980. An Assessment of Water/ Glass Interactions in Waste Glass Melter Operation. PNL-2622, Pacific Northwest Laboratory, Richland, WA. 99352.

Pye, L. D. 1979. Investigation of Controlling Mechanisms in Simulated Nuclear Waste Glass Melting and Gas Generation. Prepared for U.S. Department of Energy under Subcontract No. B-72814-A-F.

Wheelwright, E. J. et al. 1979. Technical Summary Nuclear Waste Vitrification Project. PNL-3038, Pacific Northwest Laboratory, Richland, WA 99352.

Williams, J. A. 1978. "Thermal Analys is of Glass Batch and the Effect of Water." Paper presented at the 39 th Annual Conference on Glass Problems at Ohio State University, Columbus, $\mathrm{OH}$.

Witte, L. C. and J. E. Cox. 1978. "The Vapor Explosion - A Second Look." Journal of Metals. Oct:29-35. 
$\bullet$

i 
APPENDIX A

MELTER COMPARISON TABLE 
$\bullet$ $\theta$ 


\section{TABLE A.1. Operating History of Ceramic Melters at PNL}

1. Engineering-Scale Ceramic Melter (ESCM) - Long-lived pilot-scale unit for testing candidate materials and remote operating features such as offgas containment and glass drainage.

2. Liquid-Fed Ceramic Melter (LFCM) - Full-scale unit for calcine and liquid feeding of simulated wastes.

3. Pilot-Scale Ceramic Melter (PSCM) - Pilot-scale unit for direct coupling to spray calcination equipment.

4. High-Temperature Ceramic Melter (HTCM) - Pilot-scale design for $1400^{\circ} \mathrm{C}$ glass temperatures using tin-oxide electrodes.

5. Experimental Ceramic Melter (ECM) - Laboratory-scale unit for batch formulation studies with both calcine or liquid feeds.

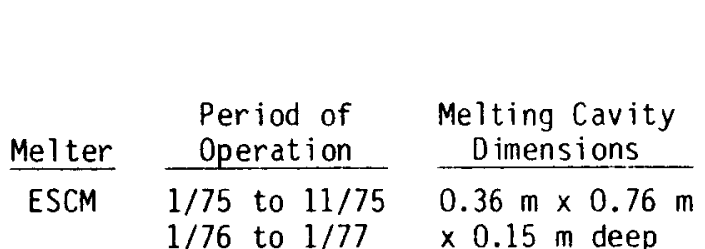

LFCM

$2 / 77$ to $2 / 80$

\section{$0.86 \mathrm{~m} \times 1.22 \mathrm{~m}$ $x 0.48 \mathrm{~m}$ deep}

PSCM

HTCM

Present

ECM $3 / 79$ to Present

$\times 0.22 \mathrm{~m}$ deep

$0.15 \mathrm{~m} \times 0.36 \mathrm{~m}$

$\times 0.15 \mathrm{~m}$ deep

\begin{tabular}{|c|c|}
\hline $\begin{array}{r}\text { Demonstrated } \\
\text { Calc ine/Frit } \\
\text { Feeding }(\mathrm{kg} / \mathrm{h}) \\
\end{array}$ & $\begin{array}{l}\text { Liquid } \\
\text { Feeding }(\mathrm{L} / \mathrm{I} \\
\end{array}$ \\
\hline \multirow[t]{2}{*}{60} & $\begin{array}{l}29 \text { Without } \\
\text { Boosting }\end{array}$ \\
\hline & $\begin{array}{l}44 \text { with } \\
\text { Boosting }\end{array}$ \\
\hline \multirow[t]{2}{*}{160} & $\begin{array}{l}100 \text { Without } \\
\text { Boosting }\end{array}$ \\
\hline & $\begin{array}{l}150 \text { (b) With } \\
\text { Boosting }\end{array}$ \\
\hline \multicolumn{2}{|l|}{85} \\
\hline \multicolumn{2}{|l|}{20} \\
\hline 10 & $\begin{array}{l}6.3 \text { without } \\
\text { Boost ing }\end{array}$ \\
\hline
\end{tabular}

Boosting

\section{Equivalent}

Waste Glass

Throughput a

10

$220 \mathrm{~kg} / \mathrm{h} / \mathrm{m}^{2}$

$106 \mathrm{~L} / \mathrm{h} / \mathrm{m}^{2}$

15

$161 \mathrm{~L} / \mathrm{h} / \mathrm{m}^{2}$

$152 \mathrm{~kg} / \mathrm{h} / \mathrm{m}^{2}$

$95 \mathrm{~L} / \mathrm{h} / \mathrm{m}^{2}$

$143 \mathrm{~L} / \mathrm{h} / \mathrm{m}^{2}$

$112 \mathrm{~kg} / \mathrm{h} / \mathrm{m}^{2}$

$164 \mathrm{~kg} / \mathrm{h} / \mathrm{m}^{2}$

2.2

$185 \mathrm{~kg} / \mathrm{h} / \mathrm{m}^{2}$

$117 \mathrm{~L} / \mathrm{h} / \mathrm{m}^{2}$

(a) Based on $0.35 \mathrm{~kg} / \mathrm{L}$ oxides; typical concentration for tests.

(b) Anticipated to be higher in future tests. 
0

0 
APPENDIX B

ACID FEEDING DATA 
$\bullet$

$\bullet$

A.2 
TABLE B.1. LFCM Liquid-Feeding Log

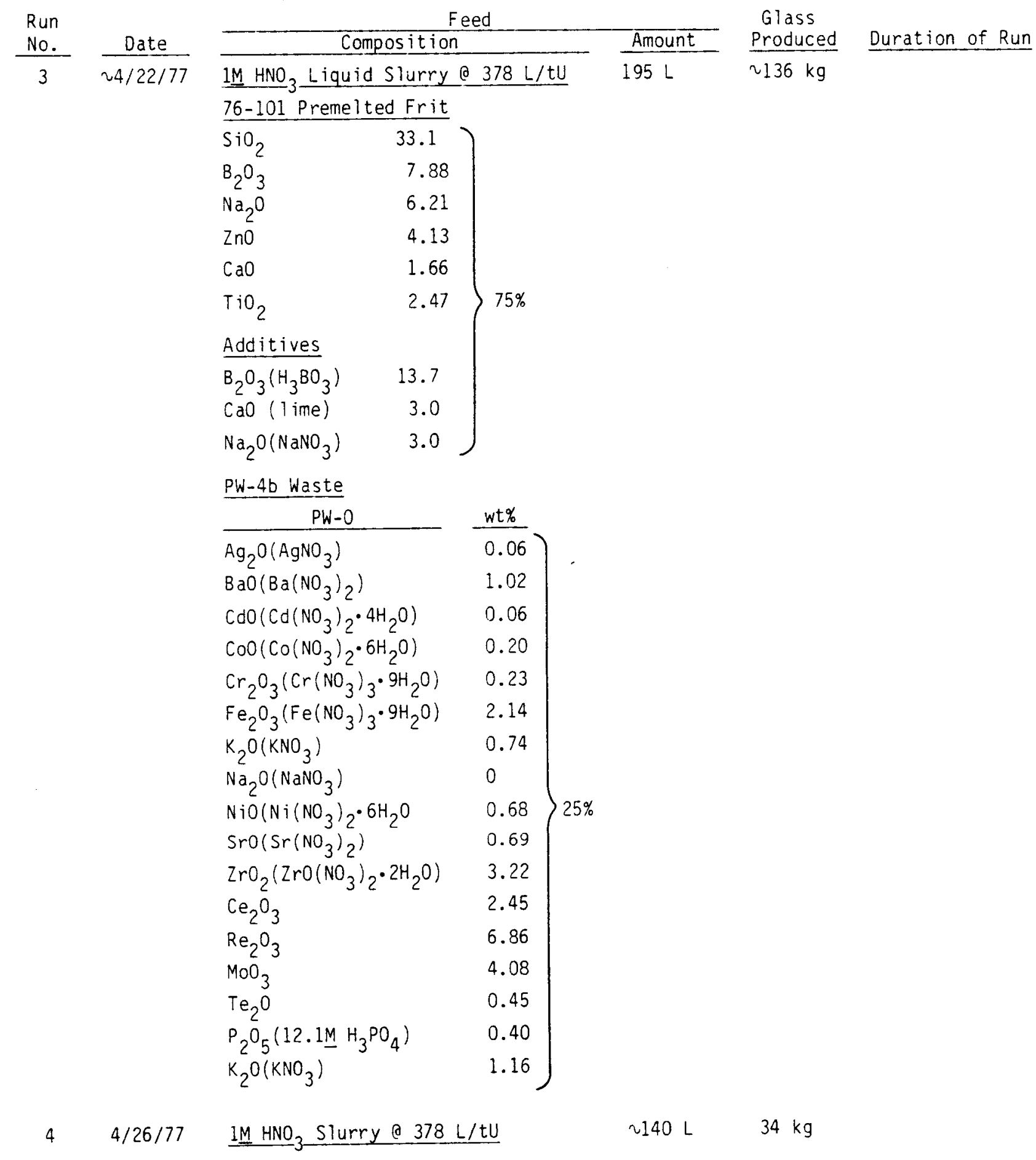


TABLE B.1. (contd)

\begin{tabular}{|c|c|c|c|c|c|c|c|}
\hline Run & & & eed & & & Glass & \\
\hline No. & Date & Composition & & & Amount & Produced & Duration of Run \\
\hline 4 & & 76-101 Premelted Frit & $-58.1)$ & & & & \\
\hline (contd) & & $\mathrm{B}_{2} \mathrm{O}_{3}\left(\mathrm{H}_{3} \mathrm{BO}_{3}\right)$ & 14.4 & & & & \\
\hline & & CaO (lime) & 3.14 & $79 \%$ & & & \\
\hline & & $\mathrm{Na}_{2} \mathrm{O}\left(\mathrm{NaNO}_{3}\right)$ & 3.14 & & & & \\
\hline & & $\mathrm{PW}-0$ & 20.6 & & & & \\
\hline & & $\mathrm{TeO}_{2}$ & 0.43 & $21 \%$ & & & \\
\hline & & $\mathrm{P}_{2} \mathrm{O}_{5}\left(12.1 \mathrm{M} \mathrm{H}_{3} \mathrm{PO}_{4}\right)$ & 0.38 & & & & \\
\hline 6 & $5 / 18 / 77$ & $1 \underline{M} \mathrm{HNO}_{3}$ Slurry & & & $500 \mathrm{~L}$ & $200 \mathrm{~kg}$ & \\
\hline & & Frit & $w t \%$ & & & & \\
\hline & & $\mathrm{SiO}_{2}$ & 32.37 & & & & \\
\hline & & $\mathrm{Na}_{2} \mathrm{O}\left(\mathrm{NaNO}_{3}\right)$ & 11.8 & & & & \\
\hline & & $\mathrm{B}_{2} \mathrm{O}_{3}\left(\mathrm{H}_{3} \mathrm{BO}_{3}\right)$ & 21.1 & $76 \%$ & & & \\
\hline & & $\begin{array}{l}\mathrm{ZnO} \\
\mathrm{TiO}_{2}\end{array}$ & $\begin{array}{l}4.03 \\
2.41\end{array}$ & & & & \\
\hline & & Waste & & & & & \\
\hline & & $P W-0$ & 22.9 & & & & \\
\hline & & $\mathrm{TeO}_{2}$ & 0.48 & $24 \%$ & & & \\
\hline & & $\mathrm{P}_{2} \mathrm{O}_{5}\left(12.1 \mathrm{M} \mathrm{H}_{3} \mathrm{PO}_{4}\right)$ & 0.42 & & & & \\
\hline 7 & $6 / 08 / 77$ & 1 M $\mathrm{HNO}_{3}$ Liquid Slurry & (see Run & 26) & $420 \mathrm{~L}$ & $2136 \mathrm{~kg}$ & \\
\hline DLF -8 & $8 / 15 / 77$ & 1 M $\mathrm{HNO}_{3}$ Liquid Slurry & (see Run & 6) & $\begin{array}{rl}731 \mathrm{LO} & 0 \\
73 \mathrm{~L} / \mathrm{h}\end{array}$ & $183 \mathrm{~kg}$ & $10 \mathrm{~h}$ \\
\hline DLF-9 & $10 / 06 / 77$ & $\begin{array}{l}60 \mathrm{~kg} \text { of Savannah Rive } \\
(\mathrm{see} \text { SRL-1) }+18 \mathrm{~L} \text { of } \\
\mathrm{HNO}_{3}+\text { water for every } \\
\text { liquid feed }\end{array}$ & $\begin{array}{l}r \text { Waste } \\
55.5 \mathrm{wt} \\
100 \mathrm{~L}\end{array}$ & & $\begin{array}{l}190 \mathrm{~L} 0 \\
114 \mathrm{~L} / \mathrm{h}\end{array}$ & $67 \mathrm{~kg}$ & $1 \mathrm{~h}, 40 \mathrm{~min}$ \\
\hline$D L F-10$ & $10 / 10 / 77$ & $\begin{array}{l}\text { Composition of DLF-9, } \\
\text { last } 110 \mathrm{~L} \text { had } 9.1 \mathrm{~L} \\
\mathrm{HNO}_{3} \text { added to every } 10 \\
\text { for }^{3} \mathrm{IM} \mathrm{HNO} \\
\text { solutior }\end{array}$ & $\begin{array}{l}\text { except } t \\
\text { f } 55.5 \mathrm{w} \\
0 \mathrm{~L} \text { of } f\end{array}$ & $\begin{array}{l}\text { he } \\
\text { t\% } \\
\text { eed, }\end{array}$ & $\begin{array}{r}273 \mathrm{~L} \mathrm{O} \\
67 \mathrm{~L} / \mathrm{h}\end{array}$ & None & $4.1 \mathrm{~h}$ \\
\hline
\end{tabular}


TABLE B.1. (contd)

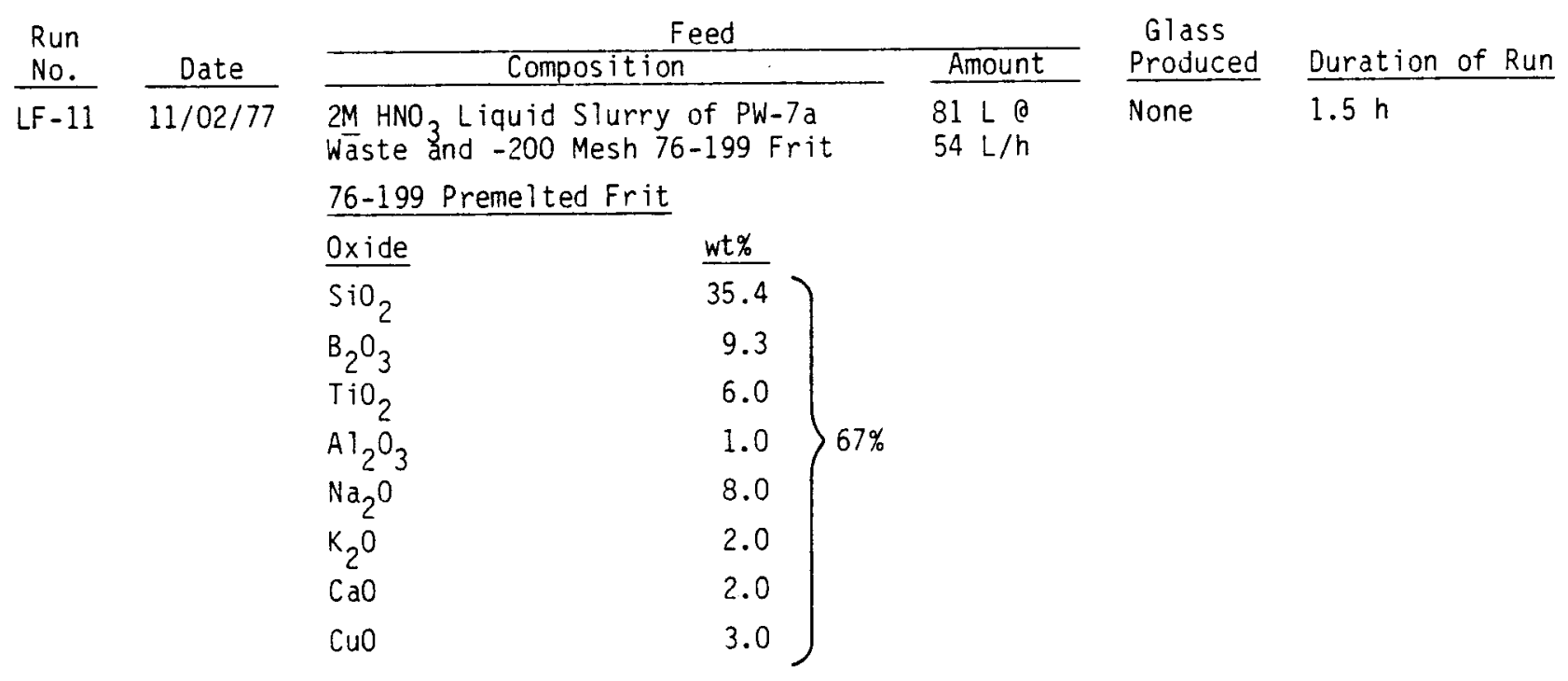

PW-7a Liquid Waste

\begin{tabular}{|c|c|}
\hline$P W-0+P W-7 a-2 m$ & wt\% \\
\hline $\mathrm{Ag}_{2} \mathrm{O}\left(\mathrm{AgNO}_{3}\right)$ & 0.04 \\
\hline $\mathrm{BaO}\left(\mathrm{Ba}\left(\mathrm{NO}_{3}\right)_{2}\right)$ & 0.76 \\
\hline $\mathrm{CdO}\left(\mathrm{Cd}\left(\mathrm{NO}_{3}\right)_{2} \cdot 4 \mathrm{H}_{2} \mathrm{O}\right)$ & 0.05 \\
\hline $\mathrm{COO}\left(\mathrm{Co}\left(\mathrm{NO}_{3}\right)_{2} \cdot 6 \mathrm{H}_{2} \mathrm{O}\right)$ & 0.14 \\
\hline $\mathrm{Cr}_{2} \mathrm{O}_{3}\left(\mathrm{Cr}\left(\mathrm{NO}_{3}\right)_{3} \cdot 9 \mathrm{H}_{2} \mathrm{O}\right)$ & 0.17 \\
\hline $\mathrm{Fe}_{2} \mathrm{O}_{3}\left(\mathrm{Fe}\left(\mathrm{NO}_{3}\right)_{3} \cdot 9 \mathrm{H}_{2} \mathrm{O}\right)$ & 2.38 \\
\hline $\mathrm{K}_{2} \mathrm{O}\left(\mathrm{KNO}_{3}\right)$ & 0.55 \\
\hline $\mathrm{Na}_{2} \mathrm{O}\left(\mathrm{NaNO}_{3}\right)$ & 3.33 \\
\hline $\mathrm{NiO}\left(\mathrm{Ni}\left(\mathrm{NO}_{3}\right)_{2} \cdot 6 \mathrm{H}_{2} \mathrm{O}\right)$ & 0.50 \\
\hline $\mathrm{SrO}\left(\mathrm{Sr}\left(\mathrm{NO}_{3}\right)_{2}\right)$ & 0.51 \\
\hline $\mathrm{ZrO}_{2}\left(\mathrm{ZrO}\left(\mathrm{NO}_{3}\right)_{2} \cdot 2 \mathrm{H}_{2} \mathrm{O}\right)$ & 3.01 \\
\hline $\mathrm{Ce}_{2} \mathrm{O}_{3}$ & 4.97 \\
\hline $\mathrm{Re}_{2} \mathrm{O}_{3}$ & 10.28 \\
\hline $\mathrm{MoO}_{3}$ & 3.07 \\
\hline $\mathrm{P}_{2} \mathrm{O}_{5}\left(12.1 \mathrm{M} \mathrm{H}_{3} \mathrm{PO}_{4}\right)$ & 3.15 \\
\hline & 0.36 \\
\hline
\end{tabular}

LF-12 11/04/77 See Run LF-11

$\begin{array}{rlll}460 \mathrm{~L} \mathrm{O} & 224 \mathrm{~kg} & 4.7 \mathrm{~h} \\ 98 \mathrm{~L} / \mathrm{h} & & \end{array}$ 
TABLE B.1. (contd)

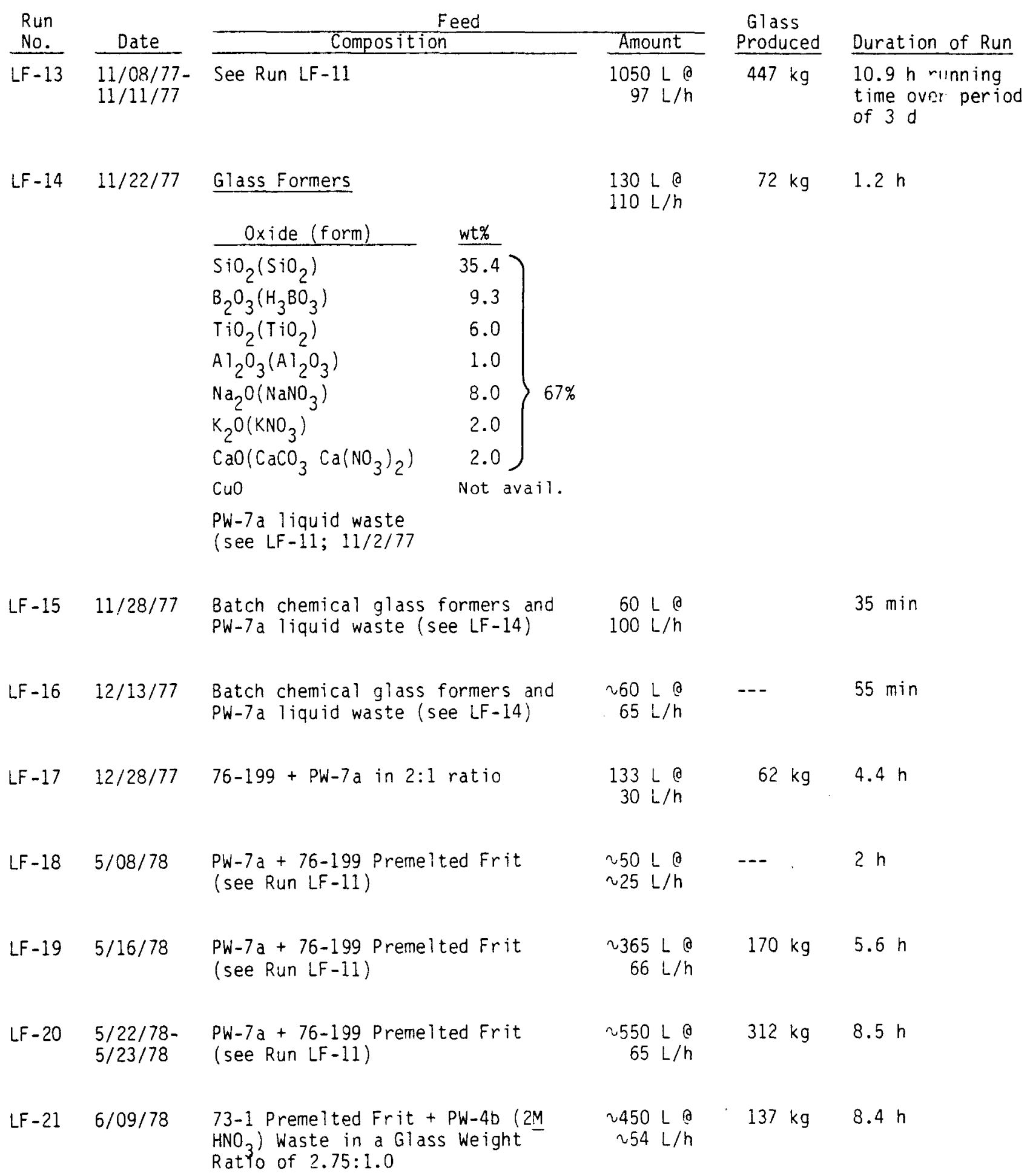


TABLE B.1. (contd)

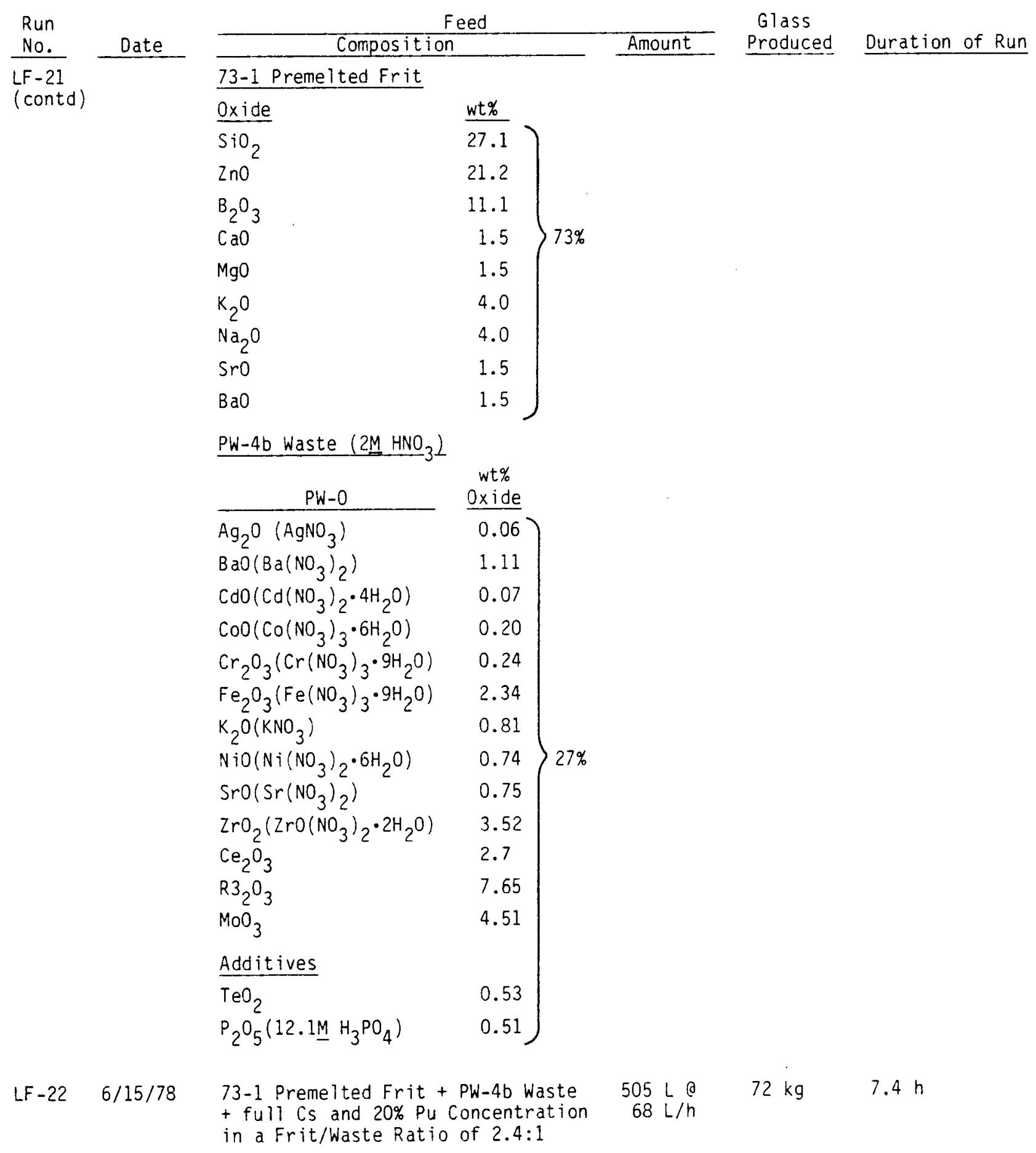

B. 5 
TABLE B.1. (contd)

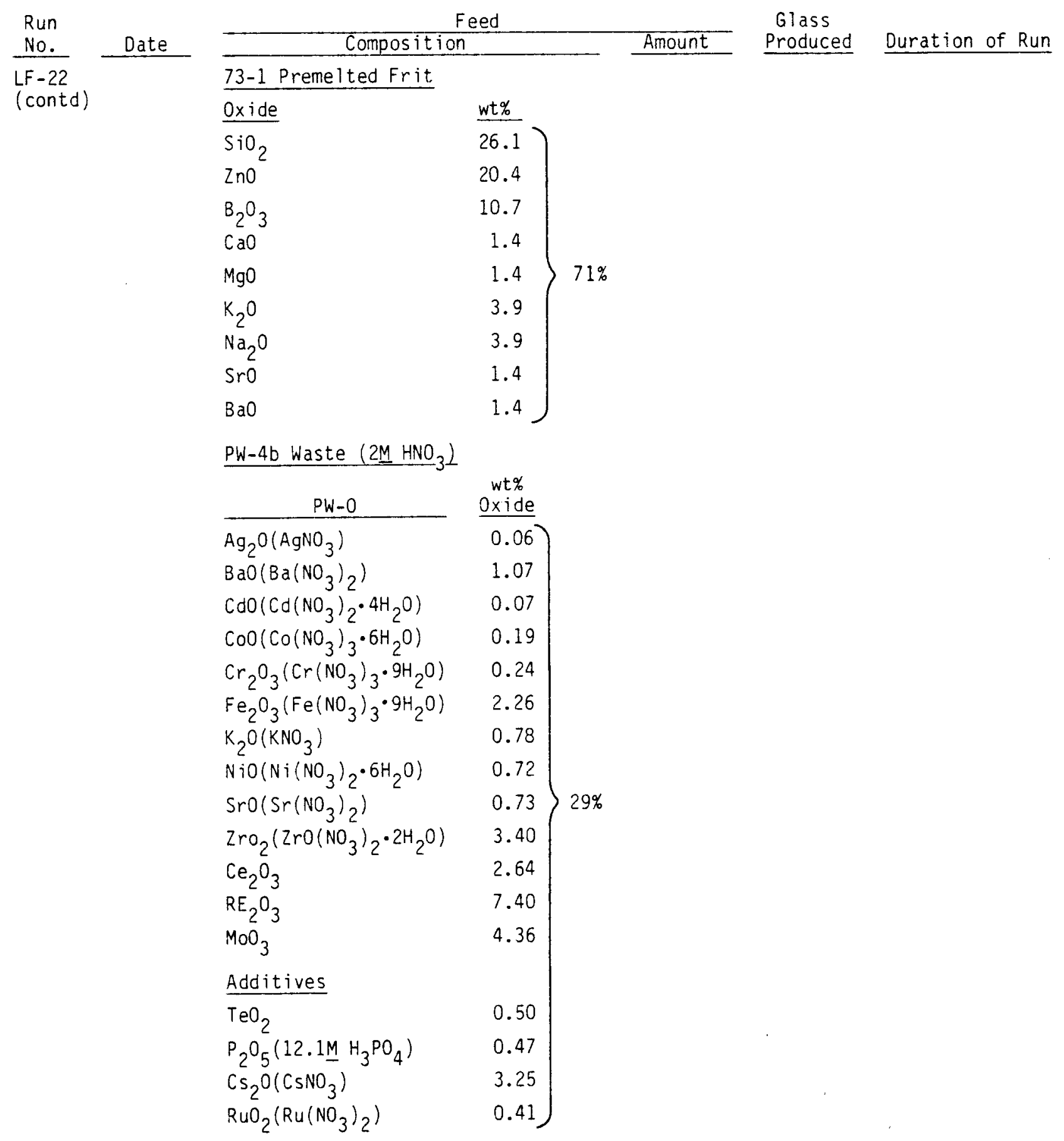


TABLE B.1. (contd)

\begin{tabular}{|c|c|c|c|c|c|}
\hline \multirow{2}{*}{$\begin{array}{l}\text { Run } \\
\text { No. }\end{array}$} & \multirow[b]{2}{*}{ Date } & \multicolumn{2}{|l|}{ Feed } & \multirow{2}{*}{$\begin{array}{l}\text { Glass } \\
\text { Produced }\end{array}$} & \multirow[b]{2}{*}{ Duration of Run } \\
\hline & & Composition & Amount & & \\
\hline$L F-23$ & $7 / 07 / 78$ & $\begin{array}{l}73-1 \text { Frit }+ \text { PW- } 4 b \text { Waste in a } 2: 1 \\
\text { Oxide Ratio }\end{array}$ & $\begin{array}{rl}703 \mathrm{~L} & 0 \\
81 \mathrm{~L} / \mathrm{h}\end{array}$ & $324 \mathrm{~kg}$ & $8.7 \mathrm{~h}$ \\
\hline$L F-24$ & $11 / 03 / 78$ & $\begin{array}{l}73-1 \text { Frit }+ \text { PW- } 4 \text { b waste in a } \\
2.5: 1 \text { Oxide Ratio, Including } 20 \% \\
\text { Ru and } 100 \% \text { Cs Loading }\end{array}$ & $415 \mathrm{~L}$ & $86 \mathrm{~kg}$ & $7.0 \mathrm{~h}$ \\
\hline \multirow[t]{6}{*}{$L F-25$} & \multirow[t]{6}{*}{$11 / 14 / 78$} & $\begin{array}{l}73-1 \text { Frit }+ \text { PW-4b Waste in } \sim 3.0: 1 \\
\text { Oxide Ratios. No Cs Added. }\end{array}$ & $\begin{array}{rl}840 \mathrm{~L} & 0 \\
68 \mathrm{~L} / \mathrm{h}\end{array}$ & $289 \mathrm{~kg}$ & $12.3 \mathrm{~h}$ \\
\hline & & Oxide & & & \\
\hline & & $P W-0)$ & & & \\
\hline & & $\left.\begin{array}{l}\mathrm{H}_{3} \mathrm{PO}_{4} \\
\mathrm{TeO}_{2}\end{array}\right\}$ & & & \\
\hline & & 73.1 Frit & & & \\
\hline & & $2 \mathrm{M} \mathrm{HNO}_{3}$ & & & \\
\hline$L F-26$ & $11 / 16 / 78$ & $\begin{array}{l}73-1 \text { Frit }+ \text { PW-4b Waste in } 23.0: 1 \\
\text { Oxide Ratio. No Cs. } 2 \mathrm{M}-\mathrm{HNO}_{3} \\
\text { Solution. }\end{array}$ & $\begin{array}{rl}430 \mathrm{LO} & 0 \\
65 \mathrm{~L} / \mathrm{h}\end{array}$ & $90 \mathrm{~kg}$ & $6.6 \mathrm{~h}$ \\
\hline$L F-27$ & $\begin{array}{l}1 / 15 / 79- \\
1 / 16 / 79\end{array}$ & $\begin{array}{l}\text { 73-1 Frit }+ \text { PW-4b Liquid Waste in } \\
\text { a 3:1 Ratio }\end{array}$ & $\begin{array}{rl}1090 \mathrm{~L} & 0 \\
51 \mathrm{~L} / \mathrm{h}\end{array}$ & $278 \mathrm{~kg}$ & $21.1 \mathrm{~h}$ \\
\hline$L F-28$ & $1 / 23 / 79$ & $\begin{array}{l}73-1 \text { Frit }+P W-4 b \text { Liquid Waste in } \\
\text { a 2.8:1 Ratio }\end{array}$ & $\begin{aligned} 430 \mathrm{~L} / 0 \\
46 \mathrm{~L} / \mathrm{h}\end{aligned}$ & $90 \mathrm{~kg}$ & $8.9 \mathrm{~h}$ \\
\hline
\end{tabular}


$\bullet$ $\theta$

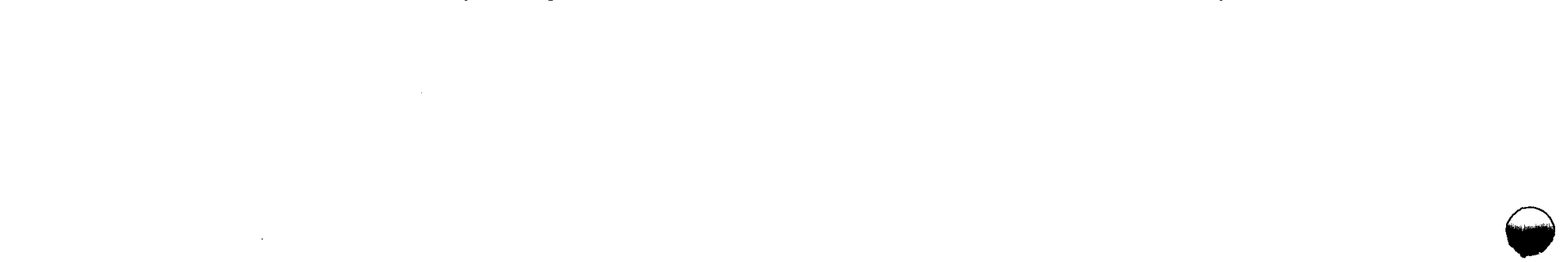


APPENDIX C

COMPOSITION OF FEED AND GLASS SAMPLES 
$\theta$ $\theta$ 


\section{TABLE C.1. Composition of Liquid Feed}

\begin{tabular}{|c|c|c|c|c|c|c|c|c|c|c|c|}
\hline \multirow[b]{2}{*}{ Date } & \multirow[b]{2}{*}{ Time } & \multicolumn{10}{|c|}{ wt\% Oxide } \\
\hline & & $\overline{\mathrm{SiO}_{2}}$ & $\underline{A I}_{2}{ }_{-3}$ & $\underline{B}_{2}-{ }_{3}$ & $\mathrm{CaO}$ & $\mathrm{Fe}_{2} \underline{O}_{3}$ & $\underline{L i}_{2} \underline{O}$ & $\mathrm{Na}_{2} \underline{0}$ & $\mathrm{MnO}_{2}$ & $\mathrm{NiO}$ & Sum \\
\hline $1 / 14 / 80$ & $\begin{array}{l}2140 \\
2330\end{array}$ & $\begin{array}{l}37.6 \\
36.9\end{array}$ & $\begin{array}{l}3.78 \\
3.28\end{array}$ & $\begin{array}{l}7.09 \\
8.50\end{array}$ & $\begin{array}{l}4.41 \\
4.04\end{array}$ & $\begin{array}{l}11.2 \\
10.3\end{array}$ & $\begin{array}{l}2.16 \\
2.36\end{array}$ & $\begin{array}{l}12.7 \\
14.5\end{array}$ & $\begin{array}{l}3.80 \\
2.85\end{array}$ & $\begin{array}{l}1.32 \\
1.20\end{array}$ & $\begin{array}{l}84.1 \\
83.9\end{array}$ \\
\hline $1 / 15 / 80$ & $\begin{array}{l}0145 \\
0330 \\
0630 \\
0908 \\
1105 \\
1250 \\
0030 \\
0230 \\
0430 \\
1710 \\
2222\end{array}$ & $\begin{array}{l}37.0 \\
36.5 \\
38.1 \\
38.1 \\
38.0 \\
38.1 \\
37.7 \\
38.1 \\
38.4 \\
38.8 \\
38.5\end{array}$ & $\begin{array}{l}3.38 \\
3.17 \\
3.70 \\
3.66 \\
3.62 \\
3.75 \\
3.57 \\
3.70 \\
3.82 \\
3.66 \\
3.61\end{array}$ & $\begin{array}{l}8.08 \\
8.60 \\
7.24 \\
7.25 \\
7.41 \\
7.18 \\
7.28 \\
7.19 \\
7.17 \\
7.37 \\
7.35\end{array}$ & $\begin{array}{l}4.14 \\
4.07 \\
4.55 \\
4.59 \\
4.54 \\
4.48 \\
4.53 \\
4.55 \\
4.61 \\
4.63 \\
4.04\end{array}$ & $\begin{array}{l}10.0 \\
10.4 \\
11.7 \\
11.8 \\
11.7 \\
11.5 \\
11.7 \\
11.6 \\
11.9 \\
12.0 \\
12.0\end{array}$ & $\begin{array}{l}2.20 \\
2.19 \\
2.20 \\
2.21 \\
2.17 \\
2.12 \\
2.05 \\
2.23 \\
2.24 \\
2.35 \\
2.25\end{array}$ & $\begin{array}{l}13.5 \\
13.7 \\
12.6 \\
12.8 \\
12.6 \\
12.3 \\
11.9 \\
12.2 \\
12.6 \\
12.2 \\
12.8\end{array}$ & $\begin{array}{l}3.02 \\
2.29 \\
2.79 \\
2.78 \\
3.28 \\
3.02 \\
3.33 \\
3.74 \\
3.11 \\
2.55 \\
2.39\end{array}$ & $\begin{array}{l}1.21 \\
1.19 \\
1.34 \\
1.35 \\
1.35 \\
1.34 \\
1.32 \\
1.37 \\
1.39 \\
1.36 \\
1.36\end{array}$ & $\begin{array}{l}83.1 \\
82.1 \\
84.2 \\
84.5 \\
84.7 \\
83.8 \\
83.4 \\
84.7 \\
85.2 \\
85.6 \\
84.9\end{array}$ \\
\hline $1 / 17 / 80$ & $\begin{array}{l}0020 \\
0125 \\
0230 \\
0335 \\
0425 \\
0525 \\
0630 \\
0755 \\
1015 \\
1245 \\
1400 \\
1500\end{array}$ & $\begin{array}{l}38.0 \\
38.2 \\
38.4 \\
38.4 \\
39.4 \\
39.6 \\
40.2 \\
39.0 \\
39.4 \\
38.3 \\
38.7 \\
38.3\end{array}$ & $\begin{array}{l}3.70 \\
3.63 \\
3.65 \\
3.54 \\
3.69 \\
3.78 \\
3.75 \\
3.77 \\
3.66 \\
3.65 \\
3.53 \\
3.44\end{array}$ & $\begin{array}{l}7.15 \\
7.40 \\
7.21 \\
7.38 \\
7.52 \\
7.67 \\
7.63 \\
7.32 \\
7.41 \\
7.21 \\
7.34 \\
7.27\end{array}$ & $\begin{array}{l}4.55 \\
4.57 \\
4.68 \\
4.72 \\
4.80 \\
4.59 \\
4.48 \\
4.40 \\
4.35 \\
4.65 \\
4.36 \\
4.48\end{array}$ & $\begin{array}{l}11.7 \\
11.8 \\
12.0 \\
12.2 \\
12.4 \\
12.2 \\
12.3 \\
12.0 \\
12.2 \\
12.3 \\
12.2 \\
12.4\end{array}$ & $\begin{array}{l}2.18 \\
2.20 \\
2.14 \\
2.18 \\
2.31 \\
2.56 \\
2.66 \\
2.48 \\
2.55 \\
2.32 \\
2.34 \\
2.28\end{array}$ & $\begin{array}{l}12.5 \\
12.6 \\
12.1 \\
12.3 \\
13.3 \\
14.2 \\
14.6 \\
13.7 \\
14.0 \\
13.2 \\
13.2 \\
13.1\end{array}$ & $\begin{array}{l}2.83 \\
1.91 \\
2.01 \\
1.02 \\
1.30 \\
1.08 \\
1.76 \\
2.54 \\
2.71 \\
2.74 \\
2.53 \\
1.32\end{array}$ & $\begin{array}{l}1.34 \\
1.32 \\
1.39 \\
1.37 \\
1.41 \\
1.34 \\
1.35 \\
1.34 \\
1.37 \\
1.35 \\
1.37 \\
1.32\end{array}$ & $\begin{array}{l}84.0 \\
83.6 \\
83.6 \\
83.1 \\
39.4 \\
86.8 \\
88.7 \\
86.6 \\
87.7 \\
85.7 \\
85.6 \\
83.8\end{array}$ \\
\hline
\end{tabular}


IABLE C.2. Composition of Liquid Feed

\begin{tabular}{|c|c|c|c|c|c|c|c|c|c|c|c|}
\hline \multirow[b]{2}{*}{ Date } & \multirow[b]{2}{*}{ Time } & \multicolumn{10}{|c|}{ g Oxide/L Feed } \\
\hline & & $\mathrm{SiO}_{2}$ & $\underline{A}_{2}{ }_{2}-{ }_{3}$ & $\underline{B}_{2} \underline{O}_{3}$ & $\mathrm{CaO}$ & $\mathrm{Fe}_{2} \mathrm{O}_{3}$ & $\underline{L i}_{2} \underline{O}$ & $\mathrm{Na}_{2} \mathrm{O}$ & $\mathrm{MnO}_{2}-$ & $\mathrm{NiO}_{2}$ & Sum \\
\hline $1,14 / 80$ & $\begin{array}{l}2140 \\
2330\end{array}$ & $\begin{array}{l}150.60 \\
144.42\end{array}$ & $\begin{array}{l}15.14 \\
12.81\end{array}$ & $\begin{array}{l}28.40 \\
33.21\end{array}$ & $\begin{array}{l}17.66 \\
15.78\end{array}$ & $\begin{array}{l}44.86 \\
40.24\end{array}$ & $\begin{array}{l}8.65 \\
9.22\end{array}$ & $\begin{array}{l}50.87 \\
56.65\end{array}$ & $\begin{array}{l}15.22 \\
11.13\end{array}$ & $\begin{array}{l}5.29 \\
4.69\end{array}$ & $\begin{array}{l}336.80 \\
328.38\end{array}$ \\
\hline $1 / 15 / 80$ & $\begin{array}{l}0145 \\
0330 \\
0630 \\
0908 \\
1105 \\
1250 \\
0030 \\
0230 \\
0430 \\
1710 \\
2222\end{array}$ & $\begin{array}{l}149.41 \\
153.30 \\
154.68 \\
153.53 \\
157.28 \\
159.59 \\
137.72 \\
201.30 \\
153.65 \\
151.70 \\
150.96\end{array}$ & $\begin{array}{l}13.65 \\
13.31 \\
15.02 \\
14.79 \\
14.98 \\
15.71 \\
13.04 \\
19.55 \\
15.28 \\
14.31 \\
14.15\end{array}$ & $\begin{array}{l}32.63 \\
36.12 \\
29.39 \\
29.29 \\
30.07 \\
30.07 \\
26.59 \\
37.98 \\
28.69 \\
28.82 \\
28.82\end{array}$ & $\begin{array}{l}16.27 \\
17.09 \\
18.74 \\
18.54 \\
18.79 \\
18.77 \\
16.55 \\
24.04 \\
18.45 \\
18.10 \\
18.19\end{array}$ & $\begin{array}{l}42.80 \\
43.68 \\
47.50 \\
47.67 \\
48.42 \\
41.17 \\
42.74 \\
61.28 \\
47.62 \\
46.92 \\
47.05\end{array}$ & $\begin{array}{r}8.88 \\
9.20 \\
8.93 \\
8.92 \\
8.98 \\
8.88 \\
7.49 \\
11.78 \\
8.96 \\
9.19 \\
8.82\end{array}$ & $\begin{array}{l}54.52 \\
57.54 \\
51.15 \\
51.71 \\
52.15 \\
51.52 \\
43.47 \\
64.45 \\
50.42 \\
50.44 \\
50.19\end{array}$ & $\begin{array}{r}12.20 \\
9.62 \\
11.33 \\
11.23 \\
13.58 \\
12.65 \\
12.16 \\
19.76 \\
12.44 \\
9.97 \\
9.37\end{array}$ & $\begin{array}{l}4.89 \\
5.00 \\
5.44 \\
5.45 \\
5.59 \\
5.61 \\
4.82 \\
7.24 \\
5.56 \\
5.32 \\
5.33\end{array}$ & $\begin{array}{l}335.57 \\
344.80 \\
341.84 \\
341.40 \\
350.56 \\
351.01 \\
304.67 \\
447.43 \\
340.91 \\
334.60 \\
332.89\end{array}$ \\
\hline $1 / 17 / 80$ & $\begin{array}{l}0020 \\
0125 \\
0230 \\
0335 \\
0425 \\
0525 \\
0630 \\
0755 \\
1015 \\
1245 \\
1400 \\
1500\end{array}$ & $\begin{array}{l}144 \\
150 \\
145 \\
146 \\
152 \\
149 \\
161 \\
146 \\
144 \\
146 \\
142 \\
144\end{array}$ & $\begin{array}{l}14.09 \\
13.96 \\
13.80 \\
13.50 \\
14.22 \\
14.26 \\
13.11 \\
14.11 \\
13.43 \\
13.98 \\
13.02 \\
12.94\end{array}$ & $\begin{array}{l}27.24 \\
28.46 \\
27.27 \\
28.15 \\
28.97 \\
28.94 \\
26.68 \\
27.40 \\
27.21 \\
27.61 \\
27.07 \\
27.34\end{array}$ & $\begin{array}{l}17.33 \\
17.57 \\
17.70 \\
18.00 \\
18.49 \\
17.32 \\
15.60 \\
16.47 \\
15.97 \\
17.81 \\
16.08 \\
16.85\end{array}$ & $\begin{array}{l}44.58 \\
45.37 \\
45.39 \\
46.53 \\
47.77 \\
46.04 \\
43.00 \\
44.92 \\
44.80 \\
47.10 \\
45.00 \\
46.64\end{array}$ & $\begin{array}{l}8.31 \\
7.69 \\
8.09 \\
8.31 \\
8.90 \\
9.66 \\
9.29 \\
9.28 \\
9.36 \\
8.88 \\
8.63 \\
8.57\end{array}$ & $\begin{array}{l}47.63 \\
48.45 \\
45.77 \\
46.91 \\
51.24 \\
53.59 \\
51.04 \\
51.29 \\
51.40 \\
50.54 \\
48.69 \\
49.27\end{array}$ & $\begin{array}{r}10.78 \\
7.35 \\
7.60 \\
3.89 \\
5.01 \\
4.07 \\
6.15 \\
9.51 \\
9.95 \\
10.49 \\
9.33 \\
4.96\end{array}$ & $\begin{array}{l}5.11 \\
5.08 \\
5.26 \\
5.23 \\
5.43 \\
5.06 \\
4.72 \\
5.02 \\
5.03 \\
5.17 \\
5.05 \\
4.96\end{array}$ & $\begin{array}{l}320.05 \\
321.49 \\
316.21 \\
316.95 \\
331.73 \\
327.46 \\
310.11 \\
324.19 \\
322.02 \\
328.14 \\
315.75 \\
144.04\end{array}$ \\
\hline
\end{tabular}


TABLE C.3. Compositions of Pour Glass Samples

\begin{tabular}{|c|c|c|c|c|c|c|c|c|c|c|}
\hline \multirow[b]{2}{*}{ Date } & \multirow[b]{2}{*}{ Time } & & \multicolumn{8}{|c|}{ wt\% 0xide } \\
\hline & & $\overline{\mathrm{SiO}_{2}}$ & $\underline{A l}_{2} \underline{-}_{3}$ & $\mathrm{~B}_{2} \mathrm{O}_{3}$ & $\mathrm{CaO}$ & $\mathrm{Fe}_{2}{ }_{-3}$ & $\underline{L i}_{2} \underline{O}$ & $\mathrm{Na}_{2} \underline{O}$ & $\mathrm{MnO}_{2}$ & $\mathrm{NiO}$ \\
\hline $1 / 15 / 80$ & $\begin{array}{l}0917 \\
1130 \\
1247 \\
1800\end{array}$ & $\begin{array}{l}46.3 \\
46.7 \\
47.3 \\
44.9\end{array}$ & $\begin{array}{l}4.12 \\
4.21 \\
4.28 \\
4.07\end{array}$ & $\begin{array}{l}8.32 \\
8.41 \\
8.50 \\
8.06\end{array}$ & $\begin{array}{l}5.08 \\
5.13 \\
5.14 \\
4.99\end{array}$ & $\begin{array}{l}12.5 \\
12.7 \\
12.8 \\
12.3\end{array}$ & $\begin{array}{l}3.07 \\
3.16 \\
3.28 \\
2.83\end{array}$ & $\begin{array}{l}16.0 \\
16.4 \\
17.6 \\
14.9\end{array}$ & $\begin{array}{l}3.66 \\
3.68 \\
3.71 \\
3.54\end{array}$ & $\begin{array}{l}1.19 \\
1.21 \\
1.23 \\
1.17\end{array}$ \\
\hline $1 / 17 / 80$ & $\begin{array}{l}0245 \\
0535 \\
0905 \\
1700\end{array}$ & $\begin{array}{l}44.6 \\
45.2 \\
45.0 \\
46.0\end{array}$ & $\begin{array}{l}4.28 \\
4.34 \\
4.33 \\
4.45\end{array}$ & $\begin{array}{l}8.13 \\
8.28 \\
8.26 \\
8.47\end{array}$ & $\begin{array}{l}5.04 \\
5.13 \\
5.10 \\
5.19\end{array}$ & $\begin{array}{l}12.8 \\
13.0 \\
13.0 \\
13.3\end{array}$ & $\begin{array}{l}2.82 \\
2.91 \\
2.93 \\
3.08\end{array}$ & $\begin{array}{l}15.2 \\
15.6 \\
15.7 \\
16.8\end{array}$ & $\begin{array}{l}3.56 \\
3.54 \\
3.42 \\
3.43\end{array}$ & \\
\hline
\end{tabular}


$\theta$

i

$\ominus$ 
APPENDIX D

PROPOSED MECHANISMS FOR FOAM GENERATION 


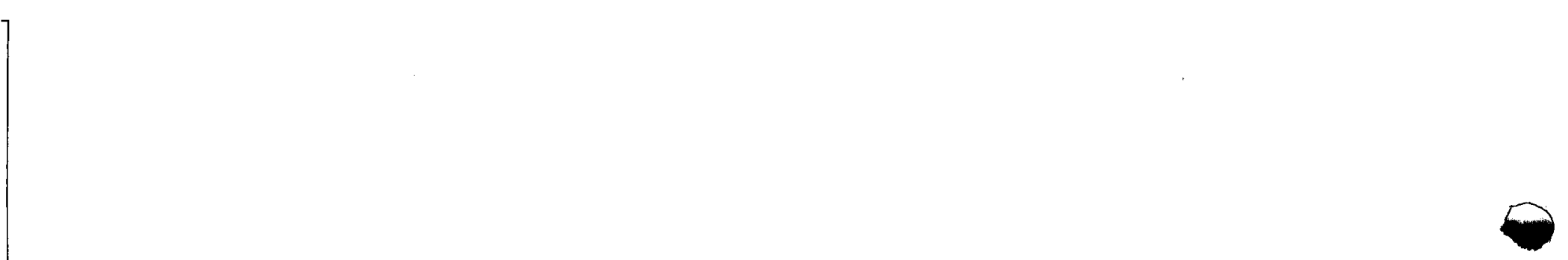

$\theta$ 0 
The current theory of foaming suggests three mechanisms for foam generation (Pye 1979). The first mechanism involves an $0_{2}$ solubility change in the melt due to a temperature change. As the melt is cooled to bring about an idling state, the melt solubility of $\mathrm{O}_{2}$ increases the melt absorbs $0_{2}$. It appears $\mathrm{CO}_{2}$ may also be absorbed in this manner. Then, as the melt is heated to begin feeding the melter, the oxidation state of some of the metals in the melt, principally $\mathrm{Fe}$ and $\mathrm{Mn}$, is lowered and $\mathrm{O}_{2}$ is released $\left(\mathrm{Fe}_{2} \mathrm{O}_{3}\right.$ heat $\left.2 \mathrm{FeO}+1 / 2 \mathrm{O}_{2}\right)$ causing foaming (foaming due to temperature changes is called "reboil"). The second mechanism is related to the first and involves the decomposition of carbon-containing compounds $\left(\mathrm{CaCO}_{3}\right.$ and cornstarch) and residual nitrates in the crust. When the melt starts foaming due to the first mechanism, some of the dried crust is engulfed in the melt. As the crust is heated the carbon is oxidized to $\mathrm{CO}_{2}$ and the nitrates are converted to $\mathrm{NO}_{\mathrm{X}}$. These gases bubble up through the melt and increase the foaming. Foaming due to this mechanism can also occur independently of the first mechanism (reboil). The third mechanism generates gases as the calcine changes state from a solid to a liquid. The liquid (molten glass) may have a lower $\mathrm{O}_{2}$ solubility than the solid; therefore, as the calcine melts, $\mathrm{O}_{2}$ may be released. 
$\theta$

$\theta$

D. 2 


\section{DISTRIBUTION}

No. of

Copies

\section{OFFSITE}

A. A. Churm

DOE Chicago Patent Group

9800 South Cass Avenue

Argonne, IL 60439

R. Y. Lowrey

DOE Albuquerque Operations Office

P. 0. Box 5400

Albuquerque, NM 87185

A. L. Taboas

DOE Albuquerque Operations Office

P. 0. Box 5400

Albuquerque, NM 87185

S. A. Mann

DOE Chicago Operations and Region Office

Argonne, IL 60439

J. Neff

Department of Energy

Columbus Program Office

505 King Avenue

Columbus, $\mathrm{OH} 43201$

W. E. Mott

DOE Division of Environmental Control Technology

Washington, DC 20545

J. P. Hamric

DOE Idaho Operations Office

550 2nd St.

Idaho Falls, ID 38401

J. W. Peel

DOE Idaho Operations office

550 2nd St.

Idaho Falls, ID 38401
No. of

Copies

J. B. Whitsett

DOE Idaho Operations office

550 2nd St.

Idaho Falls, ID 38401

C. R. Cooley

DOE Nuclear Waste Management Programs

NEW, B-107, HQ

Washington, DC 20545

G. H. Daly

DOE Nuclear Waste Management Programs

NEW, B-107, HQ

Washington, DC 20545

J. E. Dieckhoner

DOE Nuclear Waste Management Programs

NEW, B-107, HQ

Washington, DC 20545

C. H. George

DOE Nuclear Waste Management Programs

NEW, B-107, HO

Washington, DC 20545

C. A. Heath

DOE Nuclear Waste Management Programs

NEW, B-107, HQ

Washington, DC 20545

M. L. Lawrence

DOE Nuclear Waste Management Programs

NEW, B-107, HQ

Washington, DC 20545 
No. of

Copies

D. J. McGoff

DOE Nuclear Waste Management Programs

NEW, B-107, HQ

Washington, DC 20545

S. Meyers/R. Romatowski

DOE Nuclear Waste Management Programs

NEW, B-107, HQ

Washington, DC 20545

G. Oertel

DOE Nuclear Waste Management Programs

NEW, B-107, HQ

Washington, OC 20545

A. F. Perge

DOE Nuclear Waste Management Programs

NEW, B-107, HQ

Washington, DC 20545

R. W. Ramsey, Jr.

DOE Nuclear Waste Management Programs

NEW, B-107, HQ

Washington, DC 20545

D. L. Vieth

DOE Nuclear Waste Management Programs

NEW, B-107, HQ

Washington, DC 20545

R. D. Walton

DOE Nuclear Waste Management Programs

NEW, B-107, HQ

Washington, DC 20545

S. W. Ahrends

DOE Oak Ridge Operations Office

P. 0. Box E

Oak Ridge, TN 37830
No. of

Copies

D. Large

DOE Oak Ridge Operations Office

P. O. Box E

Oak Ridge, TN 37830

S. G. Harbinson

DOE San Francisco Operations Office

1333 Broadway

Oakland, CA 94612

E. S. Goldberg

DOE Savannah River Operations Office

P. 0. Box A

Aiken, SC 29801

T. B. Hindman

DOE Savannah River Operations Office

P. 0. Box A

Aiken, SC 29801

R. P. Whitfield

DOE Savannah River Operations Office

P. 0. Box A

Aiken, SC 29801

Los Alamos Scient if ic Laboratory

P. 0. Box 1663

Los Alamos NM 87544

J. B. Mant in

Division of Waste Management

Nuclear Regulatory Commission Washington, DC 20555

D. M. Rohrer

Division of Waste Management Nuclear Regulatory Commission Washington, DC 20555

R. Dale Smith

Division of Waste Management Nuclear Regulatory Commission Washington, DC 20555 
No. of

Copies

R. E. Cunningham

Office of Nuclear Safety

Materials and Safeguards

Nuclear Regulatory Commission

Room 562, 7915 Eastern Avenue

Silver Springs, MD 20910

27 DOE Technical Information Center

J. A. Buckham

Allied-General Nuclear Services

P. 0. Box 847

Barnwe 11, SC 29812

A. Williams

Allied-General Nuclear Services

P. 0. Box 847

Barnwe 11, SC 29812

J. W. Bartlett

The Analytical Sciences Corp.

6 Jacob Way

Reading, MA 01867

J. H. Kittel

Argonne National Laboratory

9700 South Cass Avenue

Argonne, IL 60439

M. J. Steindler/L. E. Trevorrow Argonne National Laboratory 9700 South Cass Avenue

Argonne, IL 60439

A. Brandstetter
Battelle Memorial Institute
Office of Nuclear Waste
Isolation
505 King Avenue
Columbus, OH 43201
W. Carbiener
Battelle Memorial Institute
Office of Nuclear Waste
Isolation
505 King Avenue
Columbus, OH 43201

No. of

Copies

\author{
N. E. Carter \\ Battelle Memorial Institute \\ Office of Nuclear Waste \\ Isolation \\ $505 \mathrm{King}$ Avenue \\ Columbus, $\mathrm{OH} 43201$
}

P. L. Hofmann

Battelle Memorial Institute

Office of Nuclear Waste Isolation

505 King Avenue

Columbus, $\mathrm{OH} 43201$

M. Kehnemuyi

Battelle Memorial Institute

Office of Nuclear Waste Isolation

505 King Avenue

Columbus, $\mathrm{OH} 43201$

Beverly Rawles

Battelle Memorial Institute

Office of Nuclear Waste

I solation

$505 \mathrm{King}$ Avenue

Columbus, $\mathrm{OH} 43201$

W. H. Baker

E. I. Du Pont de Nemours \& Co. Savannah River Laboratory

Aiken, SC 29801

J. L. Crandall

E. I. Du Pont de Nemours \& Co.

Savannah River Laboratory

Aiken, SC 29801

R. G. Garvin

E. I. Du Pont de Nemours \& Co.

Savannah River Laboratory

Aiken, SC 29801

L. W. Meyer

E. I. Du Pont de Nemours \& Co.

Savannah River Laboratory

Aiken, SC 29801 
No. of

Copies

S. Mirshak

E. I. Du Pont de Nemours \& Co. Savannah River Laboratory

Aiken, SC 29801

J. A. Porter

E. I. Du Pont de Nemours \& Co. Savannah River Laboratory

Aiken, SC 29801

G. B. Levin

$E G$ \& G Idaho

P. 0. Box 1625

Idaho Falls, ID 83415

R. Williams

Electric Power Research Institute

3412 Hillview Avenue

P. 0. Box 10412

Palo Alto, CA 94304

J. L. Larocca, Chairman

Engineering Research and Development Authority

Empire State Plaza

Albany, NY 12223

Environmental Protection Agency

Technological Assessment Division (AW-559)

Office of Radiation Programs

U.S. Environmental Protection Agency

Washington, DC 20460

W. F. Holcomb

Office of Radiation Programs $(A-460)$

U. S. Environmental Protection Agency

Washington, DC 20460
No. of

Copies

D. M. Rosenbaum

Office of Radiation Programs

U.S. Environmental Protection Agency

1921 Jefferson Davis Highway

Arlington, VA 22202

R. A. Brown

Exxon Nuclear I daho

P. 0. Box 2800

Idaho Falls, ID 83401

G. L. Ritter

Exxon Nuclear Idaho

P. 0. Box 2800

Idaho Falls, ID 83401

File Copy

Exxon Nuclear Idaho

P. 0. Box 2800

Idaho Falls, ID 83401

G. E. Benedict

General Atomics Co.

P. 0. Box 81608

San Diego, CA 92138

L. H. Brooks

Gulf Energy and Environmental Systems

P. 0. Box 81608

San Diego, CA 92138

C. J. Kershner

Monsanto Research Corporation Mound Laboratory

P. 0. Box 32

Miamisburg, OH 45342

J. P. Duckworth

Plant Manager

Nuclear Fuels Services, Inc.

P. 0. Box 124

West Valley, NY 14171 
No. of

Copies

R. S. Lowrie

Oak Ridge National Laboratory

P. 0. Box $Y$

Oak Ridge, TN 37830

H. Recht

Dept. 737-710

Atomics International Division

Rockwell International

Box 309

Canoga Park, CA 91304

W. S. Bennett

Rockwell International

Rocky Flats Plant

P. 0. Box 464

Golden, CO 80401

W. Weart

Sandia Laboratories

Albuquerque, NM 87185

D. E. Harrison

Westinghouse Electric Corp.

P. 0. Box 10864

Pittsburgh, PA 15236

P. Macedo

Vitreous State Laboratory

Catholic University of America Washington, DC 20064
R. G. Post
College of Engineering
University of Arizona
Tucson, AZ 85721
L. L. Hench
Dept. of Materials Science and Engineering
University of Florida
Gainesville, FL 32611
F. K. Pittman
3508 Sagecrest Terrace
Ft. Worth, TX 76109

No. of

Copies

\section{ONSITE}

7 DOE Richiand Operations Office
E. A. Bracken
P. A. Craig
R. E. Gerton
H. E. Ransom
J. J. Schreiber
M. W. Shupe
M. J. Zamorski

7 Rockwell Hanford Operations

R. A. Deju

D. R. Gustavson

M. J. Kupfer

C. M. Manry

I. E. Reep

D. D. Wodrich

File Copy

UNC United Nuclear Industries

T. E. Dabrowski

2 Westinghouse Hanford Company

A. G. Blasewitz

G. L. Richardson

63 Pac if ic Northwest Laboratory

S. M. Barnes

W. J. Bjork lund

H. T. Blair

W. F. Bonner

R. A. Brouns (10)

J. L. Buelt

L. A. Chick

T. D. Chikalla

R. D. Dierks

M. S. Hanson

A. J. Haverfield

M. H. Henry

L. K. Holton

J. H. Jarrett 
No. of

Copies

Pacific Northwest Laboratory (contd)

D. E. Knowiton

C. A. Knox

L. T. Lakey

D. E. Larson

J. M. Latkovich

G. B. Long (2)

S. A. McCullough

J. L. McElroy

G. B. Mellinger (5)

J. E. Mendel

F. A. Miller

R. D. Nelson

R. E. Nightingale

K. H. Oma (5)

C. R. Palmer

L. L. Petkus

A. M. Platt

D. L. Prezbindowski (2)

J. M. Rusin

D. H. Siemens

S. C. Slate

R. L. Treat

J. H. Westsik, Jr.

Technical Information (5)

Publishing Coordination EI(2) 